\title{
Growth in knowledge of trainees in general practice : figures on facts
}

Citation for published version (APA):

van Leeuwen, Y. D. (1995). Growth in knowledge of trainees in general practice : figures on facts. [Doctoral Thesis, Maastricht University]. Datawyse / Universitaire Pers Maastricht. https://doi.org/10.26481/dis.19951207yl

Document status and date:

Published: 01/01/1995

DOI:

10.26481/dis.19951207yl

Document Version:

Publisher's PDF, also known as Version of record

\section{Please check the document version of this publication:}

- A submitted manuscript is the version of the article upon submission and before peer-review. There can be important differences between the submitted version and the official published version of record.

People interested in the research are advised to contact the author for the final version of the publication, or visit the DOI to the publisher's website.

- The final author version and the galley proof are versions of the publication after peer review.

- The final published version features the final layout of the paper including the volume, issue and page numbers.

Link to publication

\footnotetext{
General rights rights.

- You may freely distribute the URL identifying the publication in the public portal. please follow below link for the End User Agreement:

www.umlib.nl/taverne-license

Take down policy

If you believe that this document breaches copyright please contact us at:

repository@maastrichtuniversity.nl

providing details and we will investigate your claim.
}

Copyright and moral rights for the publications made accessible in the public portal are retained by the authors and/or other copyright owners and it is a condition of accessing publications that users recognise and abide by the legal requirements associated with these

- Users may download and print one copy of any publication from the public portal for the purpose of private study or research.

- You may not further distribute the material or use it for any profit-making activity or commercial gain

If the publication is distributed under the terms of Article $25 \mathrm{fa}$ of the Dutch Copyright Act, indicated by the "Taverne" license above, 
Growth in knowledge of trainees in general practice 
(C) Y.D. van Leeuwen, Maastricht 1995

Vormgeving en realisatie: Datawyse | Universitaire Pers Maastricht

Omslagfoto: Opleiding in Gezondheidscentrum Neerbeek / Foto R. Holthuis, Beek

\section{CIP GEGEVENS KONINKLIIKE BIBLIOTHEEK DEN HAAG}

van Leeuwen, Yvonne D. wan

Growth in knowled ge of trainees in general pranctice:

figures on facts / Yvonne D. van Leeuwen; [ill. R. Holthuis]

- Mastricht : Universitaire Pers Maastricht. - With ref. -

With summary in Dutch.

ISBN $90-2578-204-0$

Subject headings: postgraduate training ; general practitioners /

knowledge ; general practitioners. 


\section{Growth in knowledge of trainees in general practice}

\section{Figures on facts}

\section{PROEFSCHRIFT}

ter verkrijging van de graad van doctor aan de Rijksuniversiteit Limburg te Maastricht, op gezag van de Rector Magnificus, Prof.dr. M.J. Cohen, volgens het besluit van het College van Dekanen, in het openbaar te verdedigen op donderdag 7 december 1995 om 16.00 uur

door

Yvonne D. van Leeuwen

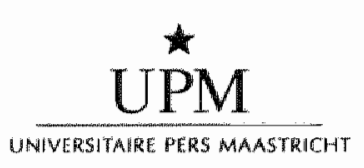




\section{Promotores}

Prof.mr.dr. R.P.T.M. Grol

Profi.dr. M.J. Drop

\section{Co-promotor}

Dr. C.P.M. van der Vleuten

\section{Beoordelingscommissie}

Prof.dr. G.G.M. Essed

Prof.dr. A.C. Nieuwenhuijzen Kruseman

Prof.dr. H.J.M. van Rossum (Rijksuniversiteit Groningen)

Prof.dr. E. Schadé (Universiteit van Amsterdam)

Prof.dr. W.H.F.W. Wijnen 
To Miss Marple

There is something I don't know that I am supposed to know.

I don't know what it is I don't know and yet I am supposed to know.

And I feel, I look stupid if I seem both to know it and not know what it is I don't know. Therefore I pretend I know it.

This is nerve-racking, since I don't know

what I must pretend to know.

Therefore I pretend to know everything.

I feel you know what I am supposed to know, but you can't tell me what it is, because you don't know that I don"t know what it is.

You may know, what I don't know, but not that I don't know it and I can't tell you.

So you will have to tell me everything.

Laing. 



\section{Contents}

PREFACE 9

CHAPTER 1: $\quad 13$

Postgraduate training for general practice and the concept and assessment of knowledge

CHAPTER 2:

The Dutch knowledge test for general practice:

issues of validity

CHAPTER 3:

Reliability of a case-based knowledge test for general-practice trainees

CHAPTER 4:

Change in knowledge of general practitioners during their professional career

CHAPTER 5:

Does the time spent by trainers on education influence the growth in knowledge of trainees in general practice?

CHAPTER 6:

Factors influencing the growth in knowledge of trainees in general practice

CHAPTER 7:

Selection for postgraduate training for general practice:

the role of knowledge tests

CHAPTER 8:

General discussion 


\section{Preface}

One derives a special kind of satisfaction from writing the preface to a dissertation. It allows one to 'speak at last', not only about the value of the study performed, but also about the hardship, the endurance, the moments of despair and, although less, of contentment.

What intrigued me from the beginning, was the fact that so much energy is put into teaching, constructing curricula, changing them, approving and criticizing them, without empirical data to go on. Which teaching is effective? What leads to the goals that are to be met? So often, these questions remain rhetorical. Sometimes it even seems that one is not too eager to get straightforward answers. Meanwhile, there is much doubt about the impact and effectiveness of certain training components, such as hospital training posts and training in scientific research.

I decided to make a start, and a start is what this dissertation is meant to be. The question, "Does postgraduale training for general practice contribute to the growth in knowledge of trainees?", should be followed by questions conceming skills, attitudes, working style, etcelera, accumulating towards the final question: "What sort of doctors do we produce?'.

Knowledge has always been my special interest. It is too easily assumed that it is part of every doctor"s stock-in-trade. Every doctor is knowledgeable in some domains and less so in others and patients gain or suffer allong with it. However, much knowledge that is transferred in medical education, even in postgraduate education, does not contribute to the competence and pertormance of doctors. It is a great challenge to ascerlain which knowledge is useful for a practitioner and as great a challenge to select the suitable means to transfer and to assess it.

I have seen the birth of the National Knowledge Test for General Practice. If the main spin-off of the present study is that a rationale for this test is provided, contributing to a fruitful use of the test in the context of postgraduate training, I have reached my goa].

Performing a scientific study makes one aware of one's own strengths and, above all, limitations. It induces personal and professional growth, although the question arises whether the price - in terms of time spent and social isolation endured - is not too high.

The greatest satisfaction for me has come from the companionship with others. The loyalty and commitment of many partners was amazing. 
The supervision provided by promotors is easily regarded as selfevident. Mostly, however, they have more "promovendi" simultaneously, each asking for a high quality of scientific and emotional guidance. I was extremely lucky with three brilliant, ingenious and humorous supervisors, Richard Grol, Riet Drop and Cees van der Vleuten. Time and again I was impressed by the scrupulousness with which they corrected my texts and ideas. It was not always easy to receive their straightforward feedback, but Il loved our meetings, which were characterized by hard work, fascinating discussions and 'gezelligheid'. Richard, thank you for your solidity, your serious wish to help me to produce quality. Riet, although you never spared me your extensive comments, you always safeguarded my well-being. Cees, you always gave me the feeling that you would never fail me and right I was.

This study was a joint venture between Marjan Pollemans and me. She completed her dissertation about knowledge testing in the context of Continuing Medical Education a year ago. Marjan, it was a privilege to work with you. Your quiet endurance was inspiring and I enjoyed our regular deliberations about designs and data. When weary of research, we changed to literature where I benefited from your fabullous wide reading. After completing your dissertation you said to me: 'So, and now we will drag you through it'. Well, that is exactly what you did. You made my texts meet the requirements of editors and transformed them into real chapters. Without your continuous support it would have taken me many months longer and perhaps I would have given up. II am extremely thankful for your loyalty.

Saskia Mol was our third research team member. She organized most of the data-gathering. Saskia, your punctuality forbade disasters. Hardly anything went wrong. Your comments, always expressed with modesty, were extremely useful. You became a precious friend.

Herman Düsman, methodologist, analysed the data. Patience characterized you, Herman. It must have been hard sometimes to communicate with a medical doctor who is more or less an asylum seeker in the field of social sciences. I will never forget your psychometric love-declaration, in answer to my hesitating plea to do yet another analysis: ' $Y$ 'vonne, ask me any analysis you fancy. I will do it'. Much I owe to the team in Utrecht which represents the collaboration between the institutes for postgraduate training for general practice in the Netherlands and particularly to Lisa Tan, Just Eekhof, Anneke Kramer, Gertie Buys, Elbrig Pasma and Hans Eekhout. They were responsible for the production of the knowledge tests and gave me all the advice and assistance I needed. Lisa and all others, the knowledge test was our common pride and this study was our shared project. I miss my regular journeys to Utrecht. Do regard this thesis as a 'Utrecht' product'. 
Vic Dubois, coordinator of postgraduate training in Maastricht, created the opportunity for me to start this project. Vic, you encouraged me to undertake this enterprise and provided the necessary conditions. You were the motor behind it all. Howewer, I also needed the consent of the postgraduate training team in Maastricht. They were obliged to take over several of my tasks. They gladly did so, allowing me to focus my attention fully on my study. Dear colleagues, please know, that I never took it for granted.

Long ago, Maarten Verwijnen taught me the 'craft' of writing test items in such an enthusiastic way that I still like doing it. He introduced the case-related test items of which the GP knowledge test now exists. Marrten, I regard you as the founding father of this test format and I owe my fascination for knowledge testing to you!

Thank you, Bob Wilkinson, for teaching me scientific English and for correcting all my texts and Laura Winkelman, Melanie van der Veeke and Karin Vaessen for your secretarial assistance.

A special thank you to the trainees, trainee-supervisors and trainers who were the 'subjects' in this study! In fact they were my most important partners!

There is no better remedy against scientific worries than doing surgery, especially as part of the wonderful team of Gezondheidscentrum Neerbeek. We rarely discussed my research activities, but any request for an extra study leave was granted without hesitation. Math, Marc, Mieke and also Paula and her team, thank you for your kindness, flexibility and the moments of relaxation which being with you meant to me.

This thesis refers, among others, to the influence of the trainer. It was my hypothesis that this influence was substantial. I could, alas, not prove it. In my case, however, it was! It all began in 1978 , when I started my GP-training in the practice of Jo Baggen. He taught me general practice with passion and brilliance. He stood model for my idea of a GP expert and urged me to explore the knowledge 'necessary and sufficient' 10 perform well in practice. His lessons influenced me for life.

If I were a man, I would - in this era - not dare to thank my partner for the lovely cooking and the nice homely atmosphere created. As a woman, I am allowed to do so.

Thank you, Jo, for all this and for your invaluable saying that has kept echoing in my mind all these years: The only way to finish a nasty job is ... begin and just hang on. 
Chapter 1

\section{Postgraduate training for general practice and the concept and assessment of knowledge}

If you think education is expensive,

do try the costs of ignorance

\section{A. Marx}




\section{Introduction}

The general practitioner plays a central role in the Dutch health care system. All health problems are first presented to the GP and only about $6 \%$ of these are referred to specialists. ${ }^{1}$ The GP is expected to be both expert on and adviser for a wide range of health problems, presented by people of all age groups and of different backgrounds. In view of this comprehensive task thorough postgraduate training is a prerequisite.

Postgraduate training for general practice in the Netherlands consists of a three-year training period with specified learning objectives and an extensive curriculum. ${ }^{2,3}$ The core element of the training is working and learning in general practice under the supervision of a GP trainer.

Although this training seems to prepare the GP well for his task, there is no scientific evidence that this is actually the case. There is a need for studies that portray the competence of the general practitioner at the moment of certification and that identify the enhancing factors. The outcomes of these studies would enable the profession to give account to society for its investment in the training and could lead to further improvement of the curriculum. Issues concerning the selection of trainees and practices, to the training of trainers and to the content of courses and seminars could be discussed on the basis of objective data.

This dissertation addresses the assessment of 'medical knowledge for general practice' and is a first attempt to elucidate the impact of the separate training components on the growth in knowledge of the future general practitioner.

\section{Postgraduate training for general practice in the Netherlands}

\section{History}

Since 1975, specialty training for general practice in the Netherlands has been compulsory for those who intend to start their own practice. It follows on six years of basic medical training. The departments of general practice of the eight medical schools in the Netherlands, usually referred to as 'training institutes', are responsible for the implementation of the training and the quality of the 'outcome'. Initially, the training consisted of a training period of at least nine months in general practice and of at most three months in hospital. In 1986 a proposal for a curriculum of three years was presented, which was based on the 'Job Description of the Dutch General Practitioner', itself formulated and accepted by the profession in $1982 .^{4} \mathrm{~A}$ broad set of specified learning objectives was formulated ${ }^{2}$ The government consented to preliminary extension of the training to two 
years, pending data that would indicate the indispensability of the third year. In 1990 a report was presented which gave an overview of the deficiencies still present in the two-year curriculum. Negotiations with the government led to formal consent for extension to three years in September 1994.

This study was performed in 1992 and 1993 and relates to the two-year curriculum.

\section{Structure and content}

The training consists of three blocks of about equal length, each with specified learning objectives. * During the first block training takes place in general practice. The main purpose is to offer the trainee the opportunity to acquire competence in the diagnosis and management of "common complaints" and diseases with a high incidence. During the second block training takes place in general hospitals, geriatric hospitals and/or ambulatory care units for psychosocial problems. It is intended to provide opportunities for the trainee to eliminate deficiencies, predominantly on patient problems with high relevance but low incidence in the primary care setting, such as acute manifestations of cardiovascular diseases. For the third block training reverts to general practice, where the trainee is expected to focus on more complex problems in general practice, including the management of chronic illness, continuity of care and family counselling. Some institutes provide a new practice for this period, whereas others prefer the trainees to continue their training in the original practice.

One day a week, the trainees attend group meetings of 12 to 13 trainees, the so called 'day release courses', organized by the training institute. The trainees discuss their experiences in practice, attend seminars supervised by experts, and train communication and technical skills. Most institutes have a fixed programme for the majority of their day release courses; some attume their programme to the needs and preferences of individual trainee groups. One half day a week is reserved for self directed leaming.

Training in general practice under the supervision of an experienced general practitioner forms the core element of postgraduate training. After a short period in which the trance observes the trainer during consultation. the trainee starts 10 work independently. He sees pallients in his own surgery room, consulting his trainer when necessary. A daily session is planned for discussion of the patients seen, the problems met, themes of interest and progress in learning. The format and content of the sessions are attuned to the phase of training. 6 Trainers receive a compulsory

* The structure of the two-year and three-year curriculum is identical. In 1994 each of the three blocks has been extended from eight to twelve months. 
introductory course to prepare them for their task. They receive follow-up training on a regular basis.

\section{Assessment}

There is no certifying examination at the end of the training. At the end of the first block, however, the trainee needs formal approbation of the institute to continue training. The institute gives consent if the trainer and the staff members involved declare that in all probability an acceptable level of competence and performance will be reached at the end of training. Crucial for this declaration is the trainee's performance in practice which is assessed by the trainer. The trainer is obliged to base his judgement on repeated observations and solid argumentation, which is checked by the staff of the training institute.

The trainee's competence is assessed by means of tests. Until 1986 , appropriate tests were not available. This deficiency was the reason to set up a permanent working group responsible for the development of competence tests on a nationwide scale. Tests for knowledge, technical skills and communication skills are in different stages of development and implementation. Tests that are administered regularly, the knowledge test and different versions of a communication skills test, have had, until now, only an educational or 'diagnostic' function: they serve as indicators for deficiencies in order to help the trainees to direct their study efforts.

During the last decade a number of validation studies have been performed. $\operatorname{Tan}^{7}$ validated a self-assessment instrument for 'educational exposure" to somatic disorders and technical skills during postgraduate training. Van Thiel et al., ${ }^{8,9}$ Bensing, ${ }^{10}$ Tan et al., 11 and Pieters et al. ${ }^{12}$ studied the validity and reliability of instruments for the assessment of communication skills. A simular study for a technical skills test is in progress. ${ }^{13}$ The validity and reliability of the knowledge test have been investigated recently and are discussed by Pollemans ${ }^{14}$ and in this dissertation.

\section{Research on postgraduate training for general practice}

\section{National: assessment of competence}

In 1983 attention was drawn to the lack of studies addressing the outcome of postgraduate training for general practice in the Netherlands. ${ }^{15}$ Several years later Bulte et al. compared the one-year training of two institutes, which differed considerably in structure and content of the day release courses. ${ }^{16}$ One training institute offered the trainees a fixed programme of courses and seminars. The other attuned its programme to the needs of 
each specific group of trainees. Outcome variables were knowledge. assessed by a written knowledge test, attitudes, assessed by a questionnaire, communication skills and the medical-technical content of the consultation, assessed by scoring of real-life consultations in practice. Change in the intended direction was demonstrated for both institutes on all the outcome variables with somewhat better results for trainees from the institute with a more structured curriculum. ${ }^{17}$

\section{National: postgraduate training}

Several studies have addressed the content of the curriculum in order to detect deficiencies. The methods applied vary from an inventory of the appreciation of trainees and ex-trainees of their curriculum ${ }^{18}$ to registration of morbidity seen by the trainee ${ }^{19}$ and the content of the one-day release courses ${ }^{20}$. Most authors demonstrated deficiencies and advocated extension of the training.

It may be concluded that more than ten years after the signalled lack of studies addressing the outcome of the Dutch postgraduate training programme, relatively little progress has been made. This is remarkable in view of the fact that in the curriculum radical changes have taken place. Whether the outcome in terms of the trainee's competence compelled certain curriculum reforms, has apparently not been the leading question. Whether the reforms lead to better outcome, likewise remains unanswered. The increasing number of studies on the validity and reliability of assessment instruments, however, clears the way for outcome studies in the near future.

International

The role of the general practitioner in the health care system as well as the content, structure and duration of postgraduate training varies considerably from country to country, 21,3 which impedes close comparison of the outcome. Nevertheless, some results and methods of research from countries with a comparable health care and postgraduate training system, are worth mentioning.

International: assessment of competence

In Belgium - with a two-year postgraduate training for general practice Derese studied several aspects of the competence and performance of trainees in the first year of their postgraduate training, comparing them with their trainers and a random group of experienced Flemish GPs. ${ }^{22}$ The aspects of competence studied were knowledge (written test), risk avoid- 
ing attiude, willingness to provide information to the patient and openness to feedback (atitude questionnaires), diagnostic approach and prescription behaviour (registration). The knowledge of trainees at the end of the first training year equalled that of their trainers, the trainees" risk avoiding attitude was higher than that of the Flemish GPS while their willingness to provide information to the patients was comparable. The trainees were less open to feedback on their performance than their experienced colleagues. The diagnostic approach (e.g. guantity of laboratory tests ordered) did not differ much between the two groups whereas the trainees did prescribe more medication per patient encounter. It may be concluded that trainees show more signs of uncertainty than their experienced colleagues, which is understandable, but reach a comparable level of competence.

In the UK Byme and Freeman studied the change in knowledge and problem solving skills of trainees during their three-year training, as represented by their scores on a Multiple Choice Question test (MCQ) and a Modified Essay Question test (MEQ) at the beginning and end of their training programme." ${ }^{23}$ They demonstrated growth in both knowledge and problem solving. The scores of trainees at the end of training equalled that of their trainers. Correlations were found between the MEQ post-scores and an overall judgement of the trainee"s performance by several trainers (including specialists).

Borgiell et al. compared practicing general practitioners who had performed a residency training in family medicine and those who had not, on the following outcomes: quality of charting, procedures in periodic health examination, quality of medical care and use of indicator drugs. ${ }^{24}$ The measurement instruments were a chart audit and questionnaires. The scores in all the investigated fields were significantly higher for GPs who had performed a residency training in family medicine. The authors comment that self-selection may account for some of the results - the training is not compulsory - but that these are striking nevertheless.

\section{International: postgraduate training}

Freeman et al. sludied the influence of the knowledge and problem solving skills of the trainer, assessed again by means of the MCQ and MEQ test mentioned above, on the growth in knowledge and problem solving of the trainee. ${ }^{25}$ They demonstrated a significant positive relation between the trainers' competence and the growth in the trainees' competence, particulary for problem solving skills as assessed with the MEQ.

In the UK, Ronalds et al. inventarized factors determining the satisfaction of the trainees with their GP trainers in the context of postgraduate training in the $\cup \mathrm{K} .{ }^{26}$ Satisfaction was expressed as having received "Value for Money'. The time spent by the trainer on teaching turned out to have by far the most impact on this qualification. Other potent factors were 
teaching methods used, trainer approachability and some practice facilities, such as having an adequate library.

In Australia, Farmer and Taylor investigated the quality of teaching by trainers as assessed by family medicine postgraduate trainees, who were trained in two practices during three months each. ${ }^{27}$ The survey aimed at assessing the teaching strategies used and the trainees' appreciation of several aspects of their training. Per trainer four questionnaires were received. A score was composed that expressed the "Value of Altachment". The two variables affecting trainees" satisfaction most were 'daily patient load' and 'quality of supervision'. A patient load of less than 10 or more than 30 was negatively related to satisfaction. Satisfaction with the quality of supervision was determined by the quality of the personal and prolessional relationship with the trainer, the time spent on teaching, case review activities and regular and adequate feedback. Particularly, the trainee's high appreciation of the contribution of other practice staff to the training was demonstrated.

The 'outcome' studies discussed demonstrate an increase in comperence and/or performance in the intended direction. The studies from Belgium and the UK even demonstrate a level of competence of trainees at the end of training that equals that of certified GPS. Unfortunately, the validity and reliability of the measurement instruments are either unsatisfactory or barely discussed.

The results of the study of Freeman et al. ${ }^{25}$, in which the outcome is related to some 'process variables' are striking. They imply that the expertise of trainers as GPs is of considerable importance for their effectiveness as trainers. The study, however, has some methodological shortcomings. The reported validity and reliability of the measurement instruments are not convincing and the analyses do not account for interactional effects, for example, between the trainer as GP and the trainer as supervisor or between the practical and theoretical components of the curriculum.

The quality of the training as perceived by the trainee seens largely determined by the time spent on teaching by the trainer and the trainer's personal and professional attitude towards his trainee. Literature on the relation between the perceived quality and the outcome in terms of competence and performance is missing.

In this study general practice knowledge is chosen as outcome measure. The arguments for this choice will be amplified in the following paragraphs. 


\section{General practice knowledge}

\section{Introduction}

During the last decade research in general practice has greatly increased. The general trend to shift from 'experience-based medicine' to 'evidencebased medicine' has enhanced this development. ${ }^{28}$ The outcome of epidemiological studies provides a basis for the development of guidelines for good patient care, which are now being published in rapid succession. ${ }^{29,30}$ Knowledge of the 'state of the art' relating to the effectiveness of diagnostic procedures and therapeutic interventions has become conditional for the quality of care and an essential element of the general practitioner's medical expertise.

\section{Medical expertise}

During the last few decades the relation between knowledge, medical problem solving and medical expertise has been an object of study in the field of cognitive psychology. The origine of this type of research goes back as early as 1945 , with de Groot's study on the thinking of chess players. ${ }^{31}$ New insights into the development of medical expertise refer to the central role of knowledge in this context. ${ }^{32,33}$

Initially, medical expertise, at that time called 'clinical competence', was thought to be composed of knowledge, skills, attitudes and 'medical problem solving skills', the latter being regarded as the most essential. This problem solving skill was thought to represent an independent mental. process, predominantly consisting of hypothetico-deductive thinking, which, as was believed, could be learned. ${ }^{34}$

However, the idea of medical problem solving as an independent cognitive skill has been rejected on the basis of a new theory which is supported by empirical findings. ${ }^{35}$ This theory claims that the quality of medical reasoning is to a large extent dependent on knowledge, or more precisely, on its availability and accessibility; in other words on the volume and 'organization ' of factual information in the doctor's mind. ${ }^{36,37}$

The development of medical expertise is thought to take shape as follows. ${ }^{38,39}$ During medical education the student's volume of knowledge gradually expands. At first, isolated facts are stored as rote knowledge in the student's mind, but already in an early stage knowledge networks are 'built' which incorporate the increasing volume of facts. These networks of associated facts, called clinical concepts, enable medical reasoning to develop. From the moment they are available, new facts are placed in a logical context, which facilitates the applicability of knowledge as well as the acquisition of new knowledge. In a later stage, the knowledge networks 
become 'condensed' into pattems of signs and symptoms, so-called 'illness scripts'. 40.32 Within the field of expertise reasoning is then no longer conditional for arriving at the right conclusion. $41,42,32$ When confronted with a new problem, the student/doctor recognizes patterns of signs and symptoms instantly, by comparing the new problem with those encountered before. ${ }^{44}$ As expertise grows, founded on repeated exposure to similar problems, the illness scripts become increasingly elaborated. Beside signs and symptoms they include also facts relating to the context in which signs and symptoms become manifest, e.g. the medical and individual history of the patient. ${ }^{43}$ Recognition and interpretation of these 'contextual factors' have been found to determine to a large extent the diagnostic accuracy of general practitioners. ${ }^{43}$

In conclusion, medical expertise is acquired on the basis of:

- the quality of knowledge networks,

- the volume of factual information embedded in these networks,

- the frequency of exposure to new problems which induces condensation of networks into "illness scripts' which consequently leads to "pattern recognition'.

Implicit to this theory is that no doctor is 'an expert'. Expertise is essentially partial, depending on the domain or subdomain in which the requirements for the development of expertise are met.

The implications of the theories outlined above is that the knowledge that is essential for good patient care in general practice may be regarded as a composition of facts relevant for daily patient care, arranged in a conceptual framework which is continuously remodelled on the basis of new patient encounters. From this it may follow that postgraduate training for general practice should provide:

- sources of information for the acquisition of new knowledge and for the construction of 'knowledge networks' tailored to primary care,

- opportunities for exposure to problems in the general practice setting to induce the storage of 'illness scripts', relevant for general practice.

Courses and seminars, self-directed learning, daily patient encounters and reflection upon these may all contribute to the development of the medical expertise of the future general practitioner.

\section{Assessment of knowledge for general practice}

From the preceding paragraphs at may be concluded that the evaluation of the outcome of postgraduate training in general practice should include assessment of knowledge relevant to daily patient care in general practice. The trainee should be able to demonstrate that s/he is able to recognize and 
interpret pattems of signs, symptoms and contextual factors and to base therapeutical decisions upon these.

The question is how this should be assessed.

Although observation of real life consultations may at first sight be the method with the highest face validity, it seems doubtul to apply such a complicated and time consuming method for the present purpose. Knowledge may well be assessed by written tests, either with an open or with a closed answer format, 45 the latter being prefered for the sake of reliability and feasibility. 46

In order to avoid only trivial facts appearing in the test, ${ }^{47}$ the problem representation should be as realistic as possible, while the test items should focus on the key-features of the problem. This implies that the items relate to those aspects of the case that in real life are known to be crucial in solving the problem. For example, in the case of a periarthritis humero-scapularis this might be the interpretation of resistance tests and in the management of COPD this might be the question whether oral corticosteroids should be prescribed.

In the Netherlands a test based on these premises has been constructed and since 1987 has been administered to all general practice trainees at fixed intervals during their training. ${ }^{48}$ Successive tests are similar in structure but vary in content. Questions are included that a certified GP should be able to answer. Progress during training and the approach of trainees towards the required level of expertise can thus be monitored. ${ }^{49}$ The test consusts of written patient problems as they are usually presented to the general practitioner. An example is shown in Figure 1.

Tom Holms, 11 years old, accompanied by a school-teacher visits his GP. Ten minutes earlier someone had knocked out one of his teeth, which had fallen in the sund. Tom had put the tooth under his tongue and kept it there, knowing from his teacher that this was required. The GP cleans the tooth with a hibitane solution and replaces it in the empty socket. She then calls the dentist.

The actions regarded as adequate are:

- cleaning the tooth with a hibitane solution. T/F/?

- replacing the looth in its socket.

$\mathrm{T} / \mathrm{F} / ?$

Swart JGN. Tandletsels en fracturen van het aangezichtskelet [Dental traumas and fractures of the skull]. Bijblijven 1988; 4: 40-7.

Figure 1. Example of knowledge test case-based items. 
Trainees should interpret the signs, symptoms as well as the contextual factors included in the case description in order to arrive at the right conclusion. In this case the trainee should reckon with the fact that the boy is past the age at which teeth change; that the time between the accident and the intervention is not too long to justify further action; that the teacher"s advice is conditional for further action, that cleaning with hibitane solution prevents consolidation of the tooth, whereas insertion of the tooth in the socket should be performed as soon as possible and often results in preservation.

In conclusion, the test seems to link up to the theory of medical expertise in assessing knowledge presented in a context similar to the real life setting of the medical professional.

\section{Research questions and outline of the dissertation}

In this chapter the need for outcome studies of postgraduate training for general practice and the choice of knowledge as outcome measure has been illuminated. Moreover, a knowledge test has been described that may meet the demands of an acceptable measurement instrument.

In this study the validity and reliability of the test will be assessed, a positive result allowing its use for measuring the outcome of postgraduate training in terms of knowledge.

The main research questions relating to the impact of the different components of the training may be formulated as follows:

- What is the growth in knowledge of trainees during postgraduate training for general practice and what is the level of knowledge reached at the end of training?

- To what extent is the growth in knowledge of trainees influenced by the components of postgraduate training, e.g. patient morbidity. trainer, the practice, and theoretical education?

In chapters 2 to 7 six different studies will be described. In chapters 2 and 3 the validity and reliability of the knowledge test for general practice are discussed. In chapter 4 a transversal study is described on the growth in knowledge during the career of the general practitioner from the six th year of basic medical training onwards to more than twenty years after certification. In chapter 5 the time spent on different types of educational encounters between trainer and trainee in general practice are related to the growth in knowledge, while in chapter 6 an analysis of the impact of the different training components is presented. In chapter 7 a longitudinal study is described building on the results of the preceding studies on the 
growth in different sorts of knowledge of trainees during postgraduate training, while the predictive value of test scores early in the training for those in later training phases is discussed. Chapter 8 contains a general discussion and conclusions.

\section{References}

1 Flemming DM. The European study of referrals from primary to secondary care. [Dissertation]. Amsterdam: Thesis Publishers, 1993.

2 Dubois V, Everwijn $S$, Van Geldorp $G$, et al. The construction of a new curriculum of vocational training for general practice in the Netherlands. Utrecht: Royal Dutch Medical Association, 1987.

3 Boerma WGW, De Jong FAJM. Mulder PH. Health care and general practice across Europe. Utrecht... NIVEL/NHG, 1993.

4 Springer MP, editor. Basic job description for the general practitioner. Utrecht: Dutch National Association of General Practitioners, 1983.

5 Pollemans MC, Tan LHC. Toetsing van kwaliteit. Landelijke evaluatie van de interim-beroepsopleiding tot huisarts [rapport SV-1OH-15], Utrecht: Samenwerkingsverband-IOH, 1990.

6 Van Geldorp $\mathrm{G}$, redactie. Opleiden en leren in de huisartspraktijk. Utrecht: Bunge, 1985.

7 Tan LHC. Tekorten in de opleiding van huisartsen [Dissertation]. Amsterdam: Uniwersity of Amsterdam, 1989.

8 Van Thiel $\mathrm{J}$, Kraan $\mathrm{H}$, Van der Vleuten $\mathrm{C}$. Reliability and feasibility of measuring medical interviewing skills: the revised Maastricht History-taking and Advice Checklist. Med Educ 1991; 25: 224-9.

9 Van Thiel J. Van der Vleuten C, Kraan H. Assessment of medical interviewing skills: generalizability of scores using successive MAAS-versions. In: Harden RM, Hart IR, Mulholland $\mathrm{H}_{4}$ editors. Approaches to the Assessment of Clinical Competence. Dundee: Centre for Medical Education, 1992.

10 Bensing JM. Doctor-patient-communication and the quality of care: an observation study into affective and instrumentall behavior in general practice. Utrecht: NIVEL. 1991.

11 Tan LHC, Foolen CHGM, Van der Vleuten CPM. Ontwikkeling van de landelijke consullwoeringstoets voor de beroepsopleiding tot huisarts. Bulletin Medisch Onderwijs 1992; 11:22-33.

12 Pieters HM, Touw Otten FW, De Merker $\mathbb{R A}$. Simulated patients in asessing consultation skills of trainees in general practice vocational trainimg: a validity study. Med Educ 1994; $28: 226-33$.

13 Janssen JJM, Tan LHC, Van der Vleuten CPM, Pielage JC, Grol RPTM. Assessment of technical skills in general practice; comparing different formats for use in quality control. In: Harden RM, Hart IR, Mulholland H, editors. Approaches to the Assessment of Clinical Competence. Dundee: Centre for Medical Education, 1992.

14 Pollemans MC. Kennistoetsing bij huisartsen [Dissertation]. [Testing of knowledge of general practitioners.』 Maastricht: Datawyse/Universitaire Pers Maastricht, 1994.

15 Van Leeuwen YD. Evaluatie van de beroepsopleiding to huisarts: Toetsstenen en struikelblokken. Medisch Contact 1983; 33: 1023-6. 
16 Bulte J, Tietens V, Visser $S$, Van der Ende J, Groenier $K$. De opleiding tot huisarts in de praktijk. In: Bulte J, Van der Ende $J_{v}$ Helsper A, et al. De beroepsopleiding tot huisarts. Nijmegen: KUN, 1988.

17 Grol R, Mokkink H, Helsper-Lucas A, Tielens V. Bulte J. Etfecis of the vocational training of general practice consultation skills and medical performance. Med Educ $1989 ; 23: 512-21$.

18 Ybema $D$, Jasper $R$, Groenier $K$. Meningen en wensen van pas gevestigde huisartsen ten aanzien van de worm en inhoud wan de beroepsopleiding tot huisarts. Groningen: University of Groningen, 1983.

19 Fijten G, Kruithof MI, Muris JWM. Registratieproject arts-assistenten beroepsopleiding tot huisarts. Maastricht: University of Limburg, 1988.

20 Stolk J, Pollemans MC. Instituutsonderwijs in de beroepsopleiding tot huisarts. Bulletin Medisch Onderwijs 1991; 3: 94-9.

21 Lawrence M, Pritchard P, editors. General Practitioner Ediucation. UK and Nordic Perspectives. London: Springer Verlag, 1992.

22 Derese A. Huisarts in beroepsopleiding [Dissertation]. Ghent: University of Ghent, 1992.

23 Byme PS, Freeman J. The assessment of vocational training for general practice. Joumal of the Royal College of General Practitioners [Occasional Paper]. London: Royal College of General Practitioners, 1976.

24 Borgiel AEM, Williams II, Bass MJ, et al. Quality of care in family practice: does residency training make a difference? Can Med Assoc J1989: 1; 1035-43.

25 Freeman J, Roberts J, Metcalf D, Hillier $\mathrm{V}$. The influence of trainers on trainees in general practice. [Occasional paper 21]. London: Royal College of General Practitioners, 1982.

26 Ronalds C, Douglas A, Pereira Gray, Selley P. Fourth National Trainee Conference. Report Recommendations and Questionnaire. /Occasional paper 18]. London: Royal College of General Practitioners, 1981.

27 Farmer E, Taylor S. Assessment of teaching by family medicine programme vocational trainees. Aust Fam Physician 1990; 4:549-557.

28 Evidence-Based Medicine Working group. Evidence based health care: a new approach to teaching the practice of health care. J Dent Educ 1994; 58: 648-53.

29 Rutten GEHM, Thomas S, editors. NHG-Standaarden woor de huisarts. [Practice Guidelines for the general practitioner.] Utrecht: Bunge, 1993.

30 Grol $\mathbb{R}$, Wensing $M$, Jacobs $A$, Baker $R$, editors. Quality assurance in genemal practice. The state of the art in Europe. Utrecht: Nedlerlands Huisartsen Genootschap, 1993.

3\| De Groot AD. Het denken van den schaker. [The thinking of the chess player.] 's Gravenhage: Mouton, 1946.

32 Schmid HG, Norman GR, Boshuizen HPA. A cognitive perspective on medical expertise: theory and implications. Acad Med 1990; 65:611-21.

33. Schmidt HG, Boshuizen HPA. On acquiring expertise in medicine. Educationall Psychology Review 1993; 5: 202-21.

34 Sackett DL. Haynes RB. Tugwell P. Clinical epidemiology. A basic science for medicine. Boston/Toronto: Little Brown and Company, 1985.

35 Glaser R. Education and thinking: the role of knowledge. Am Psychol 1984; 39: 93-104.

36 Boshuizen HPA. De ontwikkeling van medische expertise. Een cognitief-psychologische benadering. [The dewelopment of medical expertise. A cognitive psycho* logical approach] [Dissertation]. Maastricht: University of Limburg, 1989. 
37 Boshuizen HPA, Schmidt $\mathrm{HG}_{*}$ Coughin LD. On the application of medical basic-science knowledge in clinical reasoning: implications for structural knowledge differences between experts and novices. In: Proceedings of the 10th Annual Conference of the Cognitive Science Society. Hillsdale, New Jersey: Lawrence Erlbaum Associates, 1988.

38 Norman GR, Rosenthal D, Brooks LR, Allen SW, Muzzin LJ. The development of expertise in dermatology. Ach Dermatol 1989: 125: 1063-8.

39 Bordage $G$, Grant $J$, Marsden P. Quantitative assessment of diagnostic ability. Med Educ 1990; $24 ; 413-25$.

40 Feltowich PJ, Barrows HS. Issues of generality in medical problem solving. In:

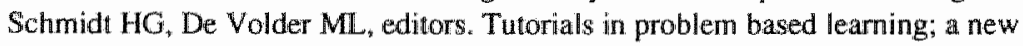
direction in teaching the health professions. Assen: van Gorcum, 1984: 128-42.

41 Patel VL, Groen GJ. Knowledge based solution strategies in medical reasoning. Cognit Sci 1986; 10: $911-116$.

42 Boshuizen HPA. De ontwikkeling van medische expertise. Een cognitief-psychologische benadering [Dissertation]. [The development of medical expertise. A cognitive psychological approach.] Maastricht: Rijksuniversiteit Limburg, 1989 .

43 Hobus P. Expertise van huisartsen [Dissertation]. [Expertise of general practitioners.] Maastricht: Rijksuniversiteit Limburg, 1994.

44 Grant J, Marsden P. The structure of memorized knowledge in students and clinicians: an explanation for diagnostic expertise. Med Educ 1987; $21: 92-8$.

45 Swanson D, Case S. Trends in written assessment: a strangely biased perspective. In: Harden RM, Hart IR, Mulholland H, editors. Approaches to the Assessment of Clinical Competence. Dundee: Centre for Medical Edication, 1992.

46 Norman G, Allery L, Berkson L et al. Research in the psychology of clinical reasoning: implications for assessment. In: Jolly B, editor. New Directions in the Assessment of Clinical Competence. Proceedings Cambridge Conference IV. Cambridge: Cambridge University Press, 1989.

47 Marshall J. Assessment during postgraduate training. Acad Med 1993; 68: 23-6.

48 Kramer AWM, Pollemans MC. Nationwide progress tests assessing knowledge in vocational training for general practice. In: Bender W, Hiemstra RJ, Scherpbier AJJA, Zwierstra RP, editors. Teaching and Assessing Clinical Competence. Groningen: Boek Werk Publ, 1990.

49 Van der Vleutern C, Verwijnen M. A system for student assessment. In: Van der Vleuten $C$, Wijnen $W$, editors. Problem-based learning: Perspectives from the Masstricht experience. Amsterdam: Thesis, 1990. 
Chapter 2

\section{The Dutch knowledge test for general practice: issues of validity}

Y.D. van Leeuwen, M.C. Pollemans, S.S.L. Mol,

J.A.H. Eekhof, R. Grol, M.J. Drop 


\section{Summary}

The Knowledge Test for General Practice is a written test administered to all trainees in the Netherlands three times a year, which implies that it offers trainees the opportunity to detect their strengths and weaknesses on a regular basis and to compare these with those of their colleagues. The test consists of about 80 patient cases with a total of 160 items. A validity study has been executed with the emphasis on content validity, which is often erroneously assumed to be existent. The procedure of test construction was evaluated, as well as the format of cases and items, whereas a test blueprint was constructed according to a fixed procedure. The test was assessed on relevance for general practice. The construct validity was examined by comparison of scores of groups of trainees of different training levels, GPs and medical students. The results warrant the conclusion that the test assesses the knowledge that is closely related to the daily work of the general practitioner and that it has the potential to illustrate growth in knowledge during training.

The adopted approach of content validation is recommended.

\section{Introduction}

In the context of vocational training of general practitioners the assessment of the competence of trainees is of major importance. Training institutions have the obligation to ascertain that trainees have the potential to perform well as a result of training, thereby giving account of their efforts to protect the public against incompetence. Moreover, the competence of trainees reflects the quality of the training; assessment of competence may point out strengths and weaknesses of the training programme. Assessment instruments, therefore, should reflect the demands of the job and the learning objectives of education.

The Dutch institutes for postgraduate training for general practice developed several tests to assess the trainees" competence: a technical skills test, a consultation skills test and a test for the assessment of the competence to apply knowledge relevant for daily practice.

The quality of this last test has been investigated. Considerable attention was given to the issue of validity. In this paper the format of the test and the process of validation will be described.

\section{Postgraduate training for general practice in the Netherlands}

Postgraduate training for general practice in the Netherlands consists of two training years in which the trainee predominantly works and learns in general practice under the supervision of a GP trainer. The training period 
in hospital is restricted to eight months at most. Once a week trainees visit their training institution to attend a "day release course" "I

The core element of the assessment of the trainees concems their skills and attitudes "on the job", which are evaluated by the trainer. The trainer's judgement is decisive for overall pass/fail decisions. Up to now, the knowledge and skills tests merely have had a dignostic and educative function; their use as instruments of programme valuation is limited. One of the reasons to reserve only a modest role for these tests in the assessment of trainees is that their qualities are not fully known.

\section{The Knowledge Test for General Practice}

The Knowledge Test for General Practice, introduced in 1987, is administered to all, about 500 , trainees in general practice in the Netherlands at fixed intervalls six times during the time of their training. All trainees take the same test regardless of their training level. The test is set at the level of the qualified general practitioner at the moment of certification. The test is thus designed to record progress during training. ${ }^{2}$

The test consists of approximately 80 patient cases with a total of 160 case-related items. ${ }^{3}$ Figure 1 presents two examples of cases and their corresponding items.

Charles Evert, 16 years old, visits his GP with the following complaint: a severe pain in his right testicle. The pain began suddenly, about an hour ago.

Examination reveals a red and swollen scrotum. Palpation is painfull. It is impossible to demarcate the epididymis from the testis. Lifting the testis increases the pain.

- In this case an epididymitis is more likely than a torsion of the testis.

$\mathrm{T} / \mathrm{F} / \mathrm{P}$

Reference: I de Boer. Textbook of Urology. Unech: Bunge, 1989:89.

Mrs Cleveland, 75 years old, is known to thave an adwanced arthrosis of her left knee. She enters the room, walking slowly and leaning to the right on her stick. The left knee is swollen and warm.

There is an effusion.

Among the therapeutical measures, indicated at this moment, is/are:

- application of icepacks

$\mathrm{T} / \mathrm{F} / \mathrm{P}$ ?

- massage and exercises

$\mathrm{T} / \mathrm{F} / \mathrm{P}$

- intra-articular injection of corticosteroids

- holding the stick in the other hand (left)

$\mathrm{T} / \mathrm{F} / ?$

Reference: AN de Wolff. Arthrosis. General Pracice 1988; 3: 65-9.

Figure 1. Examples of cases and items. 
The test material is constructed by staff members of the eight departments of general practice in the Netherlands. Five general practitioners and one educationalist review the material on relevance, content and syntax. After test administration the psychometric characteristics of the items, as well as the trainees ${ }^{7}$ comments on content and syntax, are examined. This may result in elimination of items.

Trainees receive feedback within four weeks after test administration. This feedback consists of their own scores (percentage correct/incorrect/question mark) and, as a 'point of reference', the mean score of their own training group ( 12 trainees) as well as the mean score of all Dutch trainees of the same training level.

\section{Aim of the study}

The aim of the present study was to determine the validity of the knowledge test.

There is a fair amount of literature on the validity of educational tests, presenting a number of different types of validity. 4,5 These can be reduced, however, to three main categories: content validity, construct validity and criterion validity. Ebel strongly advocates research on the content validity or 'intrinsic rational validity' of certification examinations. ${ }^{6}$ He argues that the examination is only intrinsically valid if it consists of problems that the candidates encounter during training and after certification. The choice of test problems should be rational, indicating that the rationale for selection of problems should be clear and open to discussion. Ebel's approach is often underestimated and neglected: tests often consist of items that only vaguely relate to the dilemmas encountered in daily practice, whereas validity studies do not include evaluation of the procedure of test construction. Most validity studies concentrate on criterion validity: the association is established between the scores of the test under study and those of a criterion test or 'gold standard test'. Such a gold standard test, however, is seldom available, and if so, reduces the need of construction of a new test ${ }^{7.8}$ The importance of examining the construct validity of a test is clearly pointed out by Cronbach. ${ }^{9}$ He argues that validity refers not to the test itself but to inferences from the test results, which are more or less warranted depending on preliminary assumptions, test construction, test administration and scoring.

We took Ebel's lessons to heart and gave careful attention to the content validity of our test. Therefore the construct 'general practice knowledge' was operationalized in terms of tasks encountered in reality. In addition, the construct validity of the test was examined. 
The following research questions were formulated:

- Does the test content reflect the knowledge that (future) general practitioners need to solve problems encountered in general practice (content validity)?

- Do the test results indicate that the knowledge assessed is acquired during postgraduate training (construct validity)?

These questions are operationalized as follows. The test should:

- cover the domain of general practice care,

- consist of cases such as the general practitioner encounters in daily practice, and

- focus on dilemmas that frequently arise in the context of these cases: the "heart of the matter' or key features of the problem. ${ }^{10}$

If the knowledge that is assessed is acquired during training, then test scores should increase with training level.

\section{Methods}

Methods advocated in the literature to ensure content validity of a test are: job description, expert judgement and the 'critical incident technique'. 8 The last method implies that the test content should be composed on the basis of what is crucial in daily care: issues are selected which should be mastered if patients are not to run a considerable risk of dying or of suffering severe complications. ${ }^{11}$

We adopted all three methods, although we did not comprise the test only on the basis of critical incidents, regarding such an approach as conflicting with the idea of covering the domain. However, the condition that every item should focus on the 'key feature' of the problem may be regarded as a modification of the critical incident technique. The procedure of blueprint development, which was adopted to establish the content validity of the test is presented in Table 1 and described in detail in the results section of this article.

The regular test of February 1992 was applied in this study to establish construct validity. The correct-minus-incorrect scores of trainees of six successive training levels - at 4 month intervalls - were compared. Medical students in their general practice clerkship and qualified general practitioners (mostly trainers) participated as reference groups. The test has been taken in an examination setting. The testing time was two hours on questionnaire with a five-point scale answer format. 
Table 1. Procedure of blueprint development.

\begin{tabular}{ll} 
Steps & Actions \\
\hline 1 & demarcation of the domain \\
2 & choice of classification system for main dimension \\
3 & determination of number of items for each chapter \\
4 & choice of additional dimensions \\
5 & first consultation of expert group \\
6 & formulation of definitions for each chapter of additional dimensions \\
7 & establishing interrater-reliability \\
8 & determination of number of items for each chapter of add. dimensions \\
9 & second consultation of expert group \\
10 & introduction of definite blueprint
\end{tabular}

\section{Results}

\section{Content validity}

Construction of a test blueprint. Until 1989 the test had no fixed structure, 'table of specifications' or 'blueprint' that reflected the domain of general practice care. Such a blueprint, however, was regarded as essential to meeting the assessment goals mentioned above. In order to cover the domain of general practice care it is vital to define this domain. A job description for the Dutch general practitioners, agreed upon by the profession, and translated into learning goals for postgraduate training, was available. ${ }^{12,1}$ However, a more detailed description of the intended domain was needed to serve as a basis for the blueprint. The literature provided only few examples. ${ }^{13,14}$ General practice knowledge being a concept which can be defined according to different dimensions (e.g. morbidity, sorts of care, characteristics of the population), seemed to demand a test with a multidimensional blueprint.

The American Board of General Practice had adopted such a blueprint. ${ }^{14}$ The choice of categories or chapters, however, did not meet our criteria on several points. Among others, the choice for the International Classification of Diseases as main dimension seemed inappropriate. We adopted the International Classification of Primary Care (ICPC) instead, ${ }^{15}$ considering it a better representation of the domain of general practice and of the educational objectives of postgraduate training. To include non-clinical aspects a chapter 'theoretical issues' was added.

The number of questions for each ICPC chapter was fixed by consensus, taking account of morbidity, the variety of problems within each chapter and the challenge that the different lopics offer to the general practitioner. 
Additional dimensions were chosen on the basis of relevant topics in general practice, like care for the elderly and chronic diseases. Definitions for the chapters of these dimensions were formulated.

An expert group, consisting of 25 representatives of the profession, evaluated the procedure and the suggested blueprint. This resulted in several alterations.

Assignment of items to the chapters of these dimensions according to the chapter definitions was assessed by examining the agreement between four GP classifiers. The interrater agreement, expressed as kappa varied from .74 to .79 which is fairly acceptable. For the chapters of the dimension 'course of illness', chronic versus non-chronic diseases, no satisfactory definition was found. Therefore, a list was composed consisting of diseases that normally have a chronic course, all other diseases/problems being classified as 'not chronic' by exclusion. The list was amended and accepted by the four classifiers. ${ }^{16}$

The definite blueprint is presented in Table 2 and 3.

Tablle 2. Bheprint main dimension (chapters and percentage of items for each chapter).

\begin{tabular}{lcc}
\hline Blueprint main dimension & Number of items & $\%$ \\
\hline General and unspecified (ICPC A) & \multicolumn{1}{c}{$\%$} \\
Blood and blood forming organs and lymplatics & 2 & 5 \\
(spleen, bone marrow) (ICPC B) & 10 & 1 \\
Digestive (ICPC D) & 6 & 6 \\
Eye (ICPC F) & 6 & 4 \\
Ear (ICPC H) & 16 & 4 \\
Circulatory (ICPC K) & 18 & 10 \\
Musculoskeletal (ICPC L) & 8 & 11 \\
Neurological (ICPC N) & 8 & 5 \\
Psychological (ICPC P) & 16 & 5 \\
Respiratory (ICPC R) & 12 & 10 \\
Skin (ICPC S) & 6 & 7 \\
Endocrine, metabolic and nutritional (ICPC T) & 6 & 4 \\
Urological (ICPC U) & 6 & 4 \\
Pregnancy, child-bearing, family planning (ICPC W) & 6 & 4 \\
Female genital (including breast) (ICPC X) & 6 & 4 \\
Male genital (ICPC Y) & 20 & 12 \\
Theoretical issues (including ICPC Z: social) & 160 & $100 \%$ \\
Total & &
\end{tabular}


Table 3. Blueprint, additional dimensions (chapters and percentage of cases or iterns per chapter).

\begin{tabular}{lll}
\hline Additional dimensions & & \% of cases or items \\
\hline Age of patient: & under 15 & $10-25$ of cases \\
& $15-75$ & $50-80$ of cases \\
& above 75 & $10-25$ of cases \\
Aspects of consultation: & diagnosis & $\min 40 \%$ of items \\
& treatment & $\min 40 \%$ of items \\
& medication & $\min 20 \%$ of items \\
& motherwise & $\min 20 \%$ of items \\
& miscellaneous & $\max 10 \%$ of items \\
Urgency of the problem: & emergency & $5-10 \%$ of cases \\
& no emergency & $90-95 \%$ of cases \\
Course of illness: & chronic diseases & $10-25 \%$ of cases \\
& otherwise & $75-90 \%$ of cases \\
\hline
\end{tabular}

Content validity of cases and items. The authors of test cases and items, all GPs, are instructed to describe cases they encounter in practice and to relate the test items to the 'key feature' of the problem. ${ }^{17}$ This procedure of construction of the stimulus formar ${ }^{18}$ was regarded as adequate to meet the validity criterion of similarity between test content and daily practice. The presumed disadvantage of the response format, (closed answer format): stimulating recognition instead of recall of information, was considered less important in view of the fact that the quality of the stimulus format seems decisive for validity. ${ }^{19}$

The item analysis and test takers comments sometimes resulting in elimination of items enhance validity as well. Every test is evaluated by the test takers, immediately after administration. This 'consumers opinion" is an additional check on content validity.

Table 4 illustrates the appreciation of the test takers for the subjects and items of the February 1992 test. The high approval rating is a consistent finding.

\section{Construct validity}

Table 5 presents the number of participants within each group as well as the corresponding correct-minus-incorrect scores and standard deviation. 
Table 4. Judgement of test takers conceming the content of the knowledge lest of February 1992 (in percentages).

\begin{tabular}{lccc}
\hline & $\begin{array}{c}\text { Students } \\
(\mathrm{N}=108)\end{array}$ & $\begin{array}{c}\text { Trainces } \\
(\mathrm{N}=445)\end{array}$ & $\begin{array}{l}\mathrm{GPs} \\
(\mathrm{N}=365)\end{array}$ \\
\hline $\begin{array}{l}\text { Relevance of subjects: } \\
\quad(h i g h l y) \text { relevant }\end{array}$ & 92 & 85 & 90 \\
$\quad$ undecided & 8 & 12 & 8 \\
$\quad$ (highly) irrelevant & 0 & 3 & 2 \\
& & & \\
Relevance of ilems: & & & 84 \\
$\quad$ (highly) relevant & 83 & 73 & 11 \\
$\quad$ undecided & 14 & 18 & 5 \\
$\quad$ (highly) irrelevant & 3 & 9 & \\
\hline
\end{tabular}

Table 5. Number of participants within each group (N), their corresponding mean scores (percentage correct-minus-incorrect) and standard-deviation (SD).

\begin{tabular}{|c|c|c|c|c|}
\hline Participants & $\begin{array}{l}\text { Months } \\
\text { in training }\end{array}$ & $\mathrm{N}$ & $\begin{array}{l}\text { Mean score } \\
(\% \mathrm{C}-\mathbb{C} \mathrm{C})\end{array}$ & $\mathrm{SD}$ \\
\hline Medicat studemts & & 108 & 23 & 9 \\
\hline Trainees & & 445 & & \\
\hline level 1 & 1 & 85 & $34 *$ & 10 \\
\hline level 2 & 5 & 103 & $39 *$ & 11 \\
\hline level 3 & 9 & 46 & 40 & 10 \\
\hline level 4 & 13 & 55 & 40 & 9 \\
\hline level 5 & 17 & 99 & $46^{*}$ & $\|$ \\
\hline level 6 & 21 & 57 & $49^{*}$ & 10 \\
\hline Gps & & 365 & $45^{*}$ & 11 \\
\hline \multicolumn{2}{|c|}{ Total number of participants } & 918 & & \\
\hline
\end{tabular}

* significant difference $(\mathrm{p}<0.05)$ with preceding level.

Trainees at the start of training score considerably better than medical student during their clerkship in general practice. The mean score increases with the duration of postgraduate training. The mean score of trainees at the end of training (level 6) surpasses that of qualified general practitioners. 


\section{Discussion}

The test content was examined from different perspectives: the domain and structure of the test as a whole and the content and structure of the stimulus format (cases plus items). The methods applied to construct a blueprint were job description, expert judgement and the key feature approach. This stepwise procedure turned out to be satisfactory to ensure content validity.

The conclusion is warranted that the test reflects the 'reality' of general practice, which allows inferences of test scores in terms of level of 'general practice knowledge".

The empirical data confirm the hypothesis that the test discriminates between training levels and has the potential to illustrate growth, thereby contributing to construct validity. The plateau at training level 3-4 needs further explanation. Many trainees spend their time in hospital in this period, which restricts their opportunity to study morbidity as presented in general praclice. The rather large standard deviation of GPs indicates that there is much inter-individual variation in this group. This finding is confirmed by the literature. ${ }^{20}$

It is noteworthy that the scores of trainees at the end of training surpass the scores of general practitioners. This finding was confirmed in successive tests. It may be that the trainee is favoured over the practising GP by the training setting as to the acquisition of knowledge: the trainee does not learn exclusively from seeing patients but also from discussions with the trainer and with experts and peers during the weekly day release course. Discussion and reflection may contribute to integration and consolidation of recently acquired knowledge. Consequently, GPs may rely more and more on patient-related knowledge instead of on problem-related knowledge.

It is reassuring that practising GPs appreciate the test as relevant to general practice and as useful for assessing their own knowledge. It confirms our assumption that the knowledge assessed is fairly similar to the knowledge applied in daily practice.

\section{References}

1 Dubois V, Everwiju $S$, Van Geldorp, $G$, et al. The construction of a new curriculum of vocational training for general practice in the Netherlands. Utrecht: Royal Dutch Medical Association, 1987.

2 Verwijnen GM, Imbos Tj, Snellen $\mathrm{H}$, et al. The evaluation system of the medical school of Maastricht. Assessment and Evaluation in Higher Education, 1982; 3: $225-44$. 
3 Van Leewwen YD, Van Hessen PAW. Climical competence and objective questions: Tactics to realize a true/false fomat assessing competence. In: Bender W. Hiemstra RJ, Scherpbier AJJA, Zwierstra RP, editors, Teaching and Assessing Clinical Competence. Groningen: Boek Werk publications, 1990.

4 Van Berkel HJM. De diagnose van toeisvragen [dissertation]. Amsterdam: Centrum voor Onderzoek van het Wetenschappelijk Onderwijs (COWO), Uniwersiteit van Amsterdam, 1984.

5 Neufeld VR, Norman GR, editors. Assessing Clinical Competence. New York: Springer Publishing Company, 1985.

6 Ebel $\mathbb{R}$. The practical validation of tests of ability. Educ Meas, issues pract 1983: 2:7-10.

7 Carmines EG, Zeller RA. Reliability and validity assessment. Beverly Hills/London: SAGE publications, 1985.

8 Kane MT. The validity of licensure examinations. An Psychol 1982:8; 911 -8.

9 Cronbach $L J$. What price simplicity? Comment on: The practical validation of tests of ability [Ebel R. Educ Meas, issues pract 1983:2; 7-10]. Educ Meas, issues pract 1983:2;11-2.

10 Bordage G, Page G. An alternative approach to PMP"s: the "key features' concept. In: Hart IR, Harden RM, editors. Further Developments in Assessing Clinical Competence. Montreal: Heal Publications, 1987.

11 Flanagan JC. The critical incident technique. Psychol Bull 1954: 1; 327-57.

12 Springer MP, editor. Basistakenpakket voor de huisarts | Basic job description for the general practitioner]. Utrecht: Landelijke Huisartsen Vereniging, 1983.

13 Lockie C, editor. Examination for Membership of the Royal College of General Practitioners (MRCPG). Development, current state and future trends loccasional Paper 46]. London: Royal College of General Practitioners, 1990.

14 Pisacano NJ, Veloski JJ, Brucker PC, Gonnella JS. Classifying the content of board certification examinations. Acad Med 1989: ii; 149-54.

15 Lamberts H, Wood M, editors. ICPC. International Classification of Primary Care. Oxford: Oxford University Press, 1987.

16 Pollemans MC, Van Leeuwen YD, Düsman H, Eekhof JAH, Mol SSL. Achtergronden blauwdruk huisartsgeneeskundige kennistoets [Background of the blueprint of the Dutch knowledge test for general practice]. Utrechit: Samenwerkingsverband $\mathrm{IOH}_{2} 1993$.

17 Kramer AWM, Pollemans MC, Van Leeuwen YD. Het toetsen wan kenniss in de beroepsopleiding tot huisarts [Assessment of knowledge in vocational trainingl. Medisch Contact 1990; 7:220-2.

18 Swanson $\mathrm{D}$, Case $\mathrm{S}$. Trends irn written assessment: a strangely biased perspective. In: Harden R, Hart R, Mulholland H, editors. Approaches to the Assessment of Clinical Competence. Dundee: Centre for Medical Education, 1992.

19 Van der Vleuten C. Newble D, editors. Methods of assessment in certification. In: Newble D, Jolly B, Wakeford R, editors. The Certification and Recertilication of Doctors: Issues in the Assessment of Competence. Cambridge: Cambridge University Press, 1994.

20 Day SC, Norcini JJ, Webster GD, Viner ED, Chirioco AM. The effect of changes in medical knowledge on examination performance at the time of recertification. Proceedings of the 27th Annual Conference of Research in Medical Education. Chicago, III: Association of American Medical Colleges, 1988. 

Chapter 3

\section{Reliability of a case-based knowledge test for general-practice trainees}

Y.D. van Leeuwen, M.C. Pollemans, H. Düsman, C.P.M. van der Vleuten, R.P.T.M. Grol 


\section{Introduction}

Posigraduate training for general practice in the Netherlands is a compulsory training that consists of two (since September 1994 three) years. The training is organized by eight university departments of general practice. In 1988 a new, national curriculum for postgraduate training was introduced, based on the ideas of a national committee which was installed by all eight departments." During postgraduate training the trainee works and learns mainly in general practice under the supervision of a GP trainer. The training period in hospital is restricted to one third of the training period at most. Once a week groups of twelve trainees attend a 'day release course', organized and supervised by a staff member of the department of general practice.

The assessment of the trainees has gained considerable attention. ${ }^{2}$ The core element of this assessment concerns skills and attitudes of the trainees 'on the job', which are evaluated by the trainers. The trainer's judgement is decisive for overall pass/fail decisions. Besides this, tests on knowledge, technical skills and communication skills have been developed for nationwide use. Up to now, these national knowledge and skills tests have had a merely diagnostic and predominantly educative function. Also their use as instruments of programme evaluation is limited. One of the reasons to reserve only a modest role for these tests in the assessment of trainees is that their qualities are not fully known.

In 1989 research was started on the validity and reliability of the national knowledge test. The results of the validity study are reported elsewhere ${ }^{3}$. In this article issues of reliability are discussed.

\section{The Knowledge Test}

The knowledge test consists of about 80 cases with a total of 160 case-related items. ${ }^{4,5}$ The cases are derived from general practice. Figure 1 shows an example.

The response format is of the true/false/question mark type. One mark is given for a correct answer, a negative mark for an incorrect answer, whereas no credit is given for the question mark option. The question mark option is introduced to discourage guessing as well as the habit of doctors to pretend omniscience. Consequently, the test score is composed of the total percentage correct-minus-incorrect answers. Parallel tests are administered at regular intervals during postgraduate training, to the about 500 trainees in general practice. Each time all trainees take the same test regardless of their training level. Per test trainees of six different training levels participate. The test is set at the level of general practitioners at the 
Mrs Jennifer, a 48 years old widow, tells her GP that she has been losing some urine during physical excercises and laughing. This has been so for several years. now. She comes now, because she has a new partner.

The history reveals no further symptoms. The micturtion pattern is nomal. Gynaecologic examination shows weak pelvic bottom muscles and a small prolapse. Urine analysis shows no abnormalities. The GP diagnoses (uncomplicated) stress-incontinence.

One of the suitable therapeutical interwentions in this case is:

- bladder training (e.g. increasing the intervals between micturition by 15 minutes each time).

$\mathrm{T} / \mathrm{F} /$ ?

Reference: Lagro-Janssen ALM. Het beleid bij de klach wrine-incontinemtie bj wotwen in de huisartspraktijk. Huisarts en Wetenschap 1992; 35(5): 220-3.

Figure 1. Example of a case-based test item.

moment of certification. The test is thus designed to provide longitudinal information, and to record progress during training. 4,6

The main objective in this study was to establish the reliability of the test if applied to assess the level of competence and the progress during training of individual trainees and to evaluate the training programme. Consequently this study sought to answer the following research questions:

1. What is the reliability of individual test scores?

2 . What is the reliability of group mean scores?

\section{Methods}

\section{Materials}

For purposes of analysis the correct-minus-incorrect scores of three knowledge tests were used, those of June 1991, October 1991 and February 1992. Table 1 contains the number of individuals per group for the three tests included in the analysis. For statistical analysis it was necessary to balance the number of testees per test per group of training level. Meari scores of the selected groups did not deviate from the original groups.

\section{Reliability estimates}

Reliability is not a characteristic of the test as such but varies with the object of measurement and with the interpretation of test scores. ${ }^{7}$ Generalizability theory was used as a framework to estimate reliability according to three perspectives of test score interpretation. 8,9 Reliability 
Table 1. The selected number of respondents (N) per training level, their corresponding mean scores (percentage correct-thinus-incorrect ( 6 C-IC)) and standard deviation (SD) for the tests of June 1991 (15) items), October 1991 (150 items) and February 1992 (146 items).

\begin{tabular}{|c|c|c|c|c|c|c|c|c|c|}
\hline \multirow{2}{*}{$\begin{array}{l}\text { Tratining llevel } \\
\text { (in months) }\end{array}$} & \multicolumn{3}{|c|}{ June 1991} & \multicolumn{3}{|c|}{ October 1991} & \multicolumn{3}{|c|}{ Febnuary 1992} \\
\hline & $N$ & Mean & SD & $N$ & Mean & SD & $\mathrm{N}$ & Mean & SD \\
\hline 1 & 52 & 41.7 & 10.5 & 45 & 29.3 & 8.2 & 46 & 33.3 & 10.2 \\
\hline 5 & 52 & 51.1 & 9.8 & 45 & 39.8 & 11.5 & 46 & 41.4 & 10.3 \\
\hline 9 & 52 & 50.4 & 9.3 & 45 & 36.3 & 8.8 & 46 & 40.4 & 10.1 \\
\hline 13 & 52 & 55.4 & 11.7 & 45 & 42.0 & 9.0 & 46 & 39.6 & 9.6 \\
\hline 17 & 52 & 57.3 & 9.8 & 45 & 45.7 & 9.9 & 46 & 45.7 & 9.2 \\
\hline 21 & 52 & 57.9 & 9.5 & 45 & 47.5 & 14.4 & 46 & 48.8 & 10.1 \\
\hline Total & 312 & 52.3 & 11.5 & 270 & 40.1 & 12.9 & 277 & 41.5 & 11.0 \\
\hline
\end{tabular}

of test scores of individuals may imply the following: ${ }^{9}$ Reliability of the ranking of individuals: the norm-oriented perspective. Thus defined, reliability implies that the ranking order of individual scores is reproducible from test to test. Variation in test (or item) difficulty is not relevant, because the position of an individual score in the ranking order is not related to a specific level of competence. An example is presented in Figure 2.

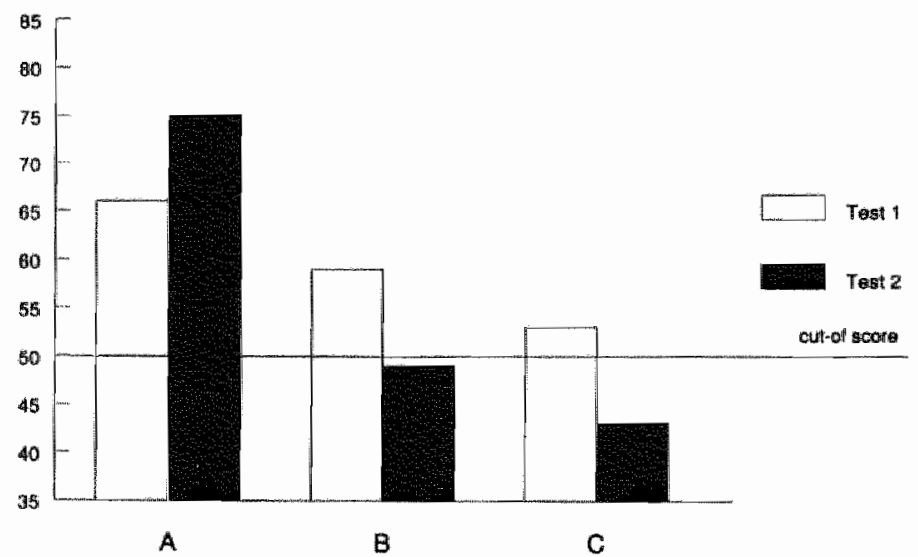

Figure 2. Example of three different reliability perspectives on test score interpretation (scores on test 1 and test 2 for testees $A, B$ and $C$ ). 
The testees $\mathrm{A}, \mathrm{B}$ and $\mathrm{C}$ score 65,59 and 53 respectively on test one, and 75,49 and 43 respectively on test two. Reliability is maximal here, because the ranking remains the same despite the fact that the scores have changed.

Reliability of the estimation of the absolute level of competence: the domain-oriented perspective. Here, individual scores represent an absolute level of competence. A score of 65 implies that the testee masters $65 \%$ of the knowledge domain of general practice. Reliability implies that the estimated level of competence is reproducible. In the example of Figure 2, reliability is less than for the norm-oriented perspective, because the absolute score for all the testees is not identical for test one and test two.

Reliability of passifail decisions: the decision-oriented or masteryoriented perspective. In this case, reliability refers only to the accuracy of the decision related to the score being above or below an established cut-off score. The absolute level of competence, its 'distance" to the cut-off score, is irrelevant: if the cut-off score in the example is 50 all three testees pass on test one, but testee $\mathrm{B}$ and $\mathrm{C}$ fail on test two, which affects reliability.

In addition, reliability of group mean scores were estimated from the three perspectives mentioned above.

\section{Statistical analysis}

For estimation of the reliability of individual scores for each of the three tests, an all random Person-by-Item ANOVA was carried out ( $\mathrm{p} x$ i design) followed by variance component estimation. Since earlier analyses indicated that case and item scores yielded equal reliability estimates, simple item scores were used for analysis here. The variance components were pooled across the three tests by averaging the components. Norm-referenced (generalizability coefficients), domain-referenced and mastery- referenced (dependability coefficients) as well as Standard Errors of Measurement (SEMs) were subsequently estimated following regular procedures. ${ }^{9}$ For the mastery-referenced score interpretation several arbitrary cut-off scores were used. The SEM reflects the size of the measurement error and may be used to estimate a confidence interval for individual scores. Adding and subtracting the SEM to/from a single examinee's score provides the $67 \%$ confidence interval within which the individual's true score will lie. Multiplying the SEM by 1.96 (the appropriate $\mathrm{z}$-value under the normal curve) provides the $95 \%$ confidence interval.

For estimation of the reliability of group mean scores, (groups of trainees of the same training level) an all random Person-nested-withinGroup-by-Items ANOVA was conducted per test (i $x(p: g)$ ) followed by variance component estimation, which were similarly pooled across tests. Subsequently, generalizability coefficients, dependability coefficients and SEMs were estimated. Reliability coefficients here may be interpreted as 
the expected correlation of group mean scores when a different sample of items and testees were used. Generalizability, dependability and SEMs are presented as a function of item sample and number of testees within groups.

\section{Results}

Table 1 presents the mean scores - percentage correct-minus-incorrect and standard deviation for the three tests of the participating groups that were selected for analyses. The scores increase with training level for all three tests. The total mean scores of the three tests differ, indicating that there is a difference in item difficulty between the tests.

\section{Reliability of individual scores}

Table 2 shows the reliability of individual scores estimated from the norm-oriented and from the domain-oriented perspective.

The reliability estimates from a norm-oriented perspective appear to be low. The degree of imprecision can be derived from the corresponding Standard Error of Measurement (SEM). The confidence interval for a test of 160 items is $12(2 \times$ SEM) and 24 (4 X SEM) for the $67 \%$ and $95 \%$ confidence level. This implies that a given score of for example 55 refers to a true score that lies between 49 and 61 with $67 \%$ certainty, and between 43 and 67 with $95 \%$ certainty. About the same applies for the reliability estimates from a domain-oriented perspective, with consequences for the absolute interpretation of test scores.

Table 3 shows reliability estimates from the decision-oriented perspective using different cut-off scores.

Table 2. Reliability and dependability coefficients and Standard Errors of Measurement (SEM) for individual scores from a norm-oriented and domain-oriented perspective, as a function of numbers of items and testing lime.

\begin{tabular}{|c|c|c|c|c|c|}
\hline \multirow[b]{2}{*}{ Iltems } & \multirow[b]{2}{*}{$\begin{array}{l}\text { lesting time } \\
\text { (hours) }\end{array}$} & \multicolumn{2}{|l|}{ norm-oriented } & \multicolumn{2}{|c|}{ domain-oriented } \\
\hline & & $\begin{array}{l}\text { generalizability } \\
\text { coefficient }\end{array}$ & SEM & $\begin{array}{l}\text { dependability } \\
\text { coefficient }\end{array}$ & SEM \\
\hline 80 & 1 & .55 & 8 & .50 & 9 \\
\hline 160 & 2 & .71 & 6 & .67 & 7 \\
\hline 240 & 3 & .79 & 5 & .75 & 5 \\
\hline 320 & 4 & .83 & 4 & .80 & 5 \\
\hline
\end{tabular}


Table 3. Dependability coefficients for individual scores from a decision-criented perspective using different cut-off scores (mean over three tests) as a function of number of items; mean score $=44 \%$ (correct-minus-incorreet).

Dependability coefficients

\begin{tabular}{cccccccccc}
\hline Items & & & & & & & & & \\
80 & .89 & .77 & .67 & .56 & .52 & .60 & .71 & .80 & .90 \\
160 & .94 & .87 & .80 & .72 & .67 & .75 & .83 & .89 & .95 \\
240 & .96 & .91 & .86 & .79 & .77 & .82 & .88 & .92 & .96 \\
360 & .97 & .93 & .89 & .89 & .81 & .86 & .91 & .94 & 97 \\
Cut-off scores & 20 & 30 & 35 & 40 & 45 & 50 & 55 & 60 & 70 \\
\hline
\end{tabular}

Reliability varies depending on the position of the cut-off score: the more distant the cut-off score is from the mean (here $44 \%$ ), the more reliable pass-fail-decisions are. With the given test length of 160 items a cut-off score of 35 or 55 yields reliability estimates of about 80 .

\section{Reliability of group mean scores}

Tables 4, 5, 6 and 7 present reliability coefficients and SEMs for group mean scores as a function of the number of items and the number of testees within groups, from the norm-oriented, domain-oriented and decisionoriented perspective.

Reliability estimates of group mean scores from the norm-oriented perspective attain .80 with groups of 15 individuals at a test length of 160 items. A test length of 80 items may be sufficient to compare groups of 25 individuals each. It is noteworthy that the differences in SEM are small: between 80 items for 10 individuals and 360 items for 25 individuals the difference is only 2 .

Reliability estimates from the domain-oriented perspective are lower, as was to be expected.

Tables 6 and 7 demonstrate that the reliability of group mean scores, even of relatively small groups, from a decision-oriented perspective, is sufficient for cut-off scores $10 \%$ from the mean. 
Table 4. Reliability coefficients (SEM in brackets) of group mean scores from a norm-oriented perspective as a function of number of individuals per group and test length (number of items).

Reliability coefficients

\begin{tabular}{clllll} 
Itenis & & & & \\
80 & $.67(4)$ & $.75(3)$ & $.79(3)$ & $.82(3)$ & $.85(2)$ \\
100 & $.69(4)$ & $.77(3)$ & $.81(3)$ & $.84(2)$ & $.86(2)$ \\
120 & $.71(3)$ & $.78(3)$ & $.82(3)$ & $.85(2)$ & $.87(2)$ \\
140 & $.72(3)$ & $.79(3)$ & $.83(2)$ & $.86(2)$ & $.88(2)$ \\
160 & $.73(3)$ & $.80(3)$ & $.84(2)$ & $.87(2)$ & $.89(2)$ \\
240 & $.76(3)$ & $.82(3)$ & $.86(2)$ & $.88(2)$ & $.90(2)$ \\
360 & $.77(3)$ & $.83(2)$ & $.87(2)$ & $.89(2)$ & $.91(2)$ \\
individuals per group & 10 & 15 & 20 & 25 & 30 \\
\hline
\end{tabular}

Table 5. Dependability coefficients (SEM in brackets) of group mean scores from a domain-oriented perspective as a function of individuals per group and test length (number of items).

Dependability coefficients

\begin{tabular}{clllll}
\hline Items & & & & \\
80 & $.50(5)$ & $.54(5)$ & $.56(5)$ & $.58(5)$ & $.59(5)$ \\
100 & $.54(5)$ & $.58(5)$ & $.61(4)$ & $.63(4)$ & $.64(4)$ \\
120 & $.57(5)$ & $.62(4)$ & $.64(4)$ & $.66(4)$ & $.67(4)$ \\
140 & $.60(4)$ & $.64(4)$ & $.67(4)$ & $.69(4)$ & $.70(4)$ \\
160 & $.62(4)$ & $.67(4)$ & $.69(4)$ & $.71(4)$ & $.72(3)$ \\
240 & $.67(4)$ & $.72(3)$ & $.75(3)$ & $.77(3)$ & $.78(3)$ \\
360 & $.71(3)$ & $.76(3)$ & $.79(3)$ & $.81(3)$ & $.82(3)$ \\
Individuals per group & 10 & 15 & 20 & 25 & 30 \\
\hline
\end{tabular}


Table 6. Dependability coefficients for group main scores from a decision-oriented perspective using different cut-off scores, as a function of number of thems and individuals per group (e.g. 15); mean score $=44 \%$ (mean $\%$ correctminus-incorrect over three tests).

Dependability coefficients

\begin{tabular}{rrrrrrrrrr}
\hline Items & & & & & & & & & \\
80 & .96 & .90 & .82 & .65 & .55 & .72 & .86 & .92 & .97 \\
160 & .98 & .94 & .88 & .75 & .67 & .82 & .91 & .95 & .98 \\
240 & .98 & .95 & .91 & .80 & .73 & .85 & .93 & .96 & .98 \\
360 & .99 & .96 & .92 & .83 & .77 & .88 & .94 & .97 & .99 \\
\multicolumn{1}{l}{ Cut-off scores } & 20 & 30 & 35 & 40 & 45 & 50 & 55 & 60 & 70 \\
\hline
\end{tabular}

Table 7. Dependability coefficients for group main scores from a decision-oriented perspective using different cut-off scores, as a function of number of items and individuals per group (e.g. 30); mean score $=44 \%$ (mean $\%$ correct-minus-incorrect over three tests).

Dependability coefficients

\begin{tabular}{rrrrrrrrrr}
\hline Items & & & & & & & & & \\
80 & .97 & .92 & .89 & .69 & .60 & .76 & .88 & .93 & .97 \\
160 & .98 & .95 & .91 & .80 & .73 & .85 & .93 & .96 & .98 \\
240 & .99 & .96 & .93 & .85 & .79 & .89 & .95 & .97 & .99 \\
360 & .99 & .97 & .95 & .88 & .83 & .91 & .96 & .98 & .99 \\
& & & & & & & & & \\
Cut-off scores 20 & 30 & 35 & 40 & 45 & 50 & 55 & 60 & 70 \\
\hline
\end{tabular}

\section{Discussion}

The reliability estimates vary considerably with the object of measurement and the perspective taken (norm, domain or decision-oriented). Starting from a given test length of $150-160$ items, corresponding with two hours of testing time, reliability of individual scores from a norm-oriented and domain-oriented perspective seems problematic. Reliability from a decision-oriented perspective with a fair range of cul-off scores seems satisfactory. It might be concluded that the overall reliability for individual scores is insufficient. However, relatively low reliability sometimes yields confidence intervals that are not substantially more extended than those 
related to (generally accepted) reliability of .80 . It shows, that this often used benchmark reliability coefficient is rather arbitrary.

Several solutions to increase reliability may be suggested. The most obvious solution is lengthening of the test. This might, however, prolong the testing time unduly and is not feasible in the present situation.

An aliemative is to aggregate the longitudinal information of two or three successive knowledge tests, across the four months intervals, although during this period the level of knowledge changes under the influence of training. A composite score of two or more tests, therefore, represents a combination of the actual level of knowledge and the growth in knowledge during the last four to eight months. For this purpose, tests should be equated to correct for differences in item-difficulty. A third alternative is using composite scores of different tests from a battery, e.g. knowledge and skills tests. A last alternative is to adopt the decisionoriented perspective. High reliability is achievable, depending on which cut-off score is selected. Here, however, it is validity that poses the essential dilemma: which cut-off score is realistic and tenable? In other words, can it be made plausible that a score below the cut-off score represents a level of knowledge that is insufficient for good performance? This issue needs further investigation.

The reliability of group mean scores is salisfactory. If fewer items are included more testees should participate and vice versa. Given a test length of 150-160 items, present group mean scores may be used in the context of programme evaluation.

The conclusion seems warranted that care should be taken in basing judgements about the trainee's level of knowledge on their individual test scores. Feedback may consist of the trainee's actual score and the total group mean score whereas the accompanying confidence interval might 'be reported' to give the trainees insight into the significance of their results. The feasibility of composite scores should be examined, as well as the validity of different cut-off scores. The use of group mean scores to evaluate the training programme should be encouraged. Either different programmes may be compared or the effect of a programme may be evaluated in a pretest-posttest design.

\section{References}

1 Dubois V, Everwijn S, Van Geldorp $G$, et al. The construction of a new curriculum of vocational training for general practice in the Netherlands. Utrecht: Royal Dutch Medical Association, 1987.

2 Pollemans MC, Van Geldorp G, Tan LHC. Naar kwaliteitsbewaking van de beroepsopleiding tor huisarts. [Towards quality assessment of vocational training of general practitioners . Medisch Contact 1988; 43(46): 1429-30. 
3 Van Leeuwen YD et at. The Dutch knowledge test for generul practices ssucs of validity. The European Joumal of General Practice, 1995: 113-7

4 Kramer AWM. Pollemans MC. Nation-wide progress tests assessing know ledge in vocational training for general practice. In Bender W. Hiemstra RU. Scherpbier AJJA, Zwierstra RP, editors. Teaching and Assessing Clinical Competenca. Groningen: Boek Werk Publ, 1990.

5 Van Leeuwen YD, Van Hessen PAW. Clinical competence and objection questions: Tactics to realize a true/false format assessing competence. In: Bender W, Hiemsira RJ, Scherpbier AJJA, Zwierstra RP. editors. Teaching and Assessing Clinical Competence. Groningen: Boek Werk publications, 1990.

6 Van der Vleuten C. Verwijnen M. A system for student assessment. In: Van der Vleuten $C$, Wijnen W, editors. Problem-based leaming: Perspectives from the Maastricht experience. Amsterdam: Thesis, 1990.

7 Thorndike RL Reliability. In: Keeves IP, editor. Educational Research, Methodology, and Measurement. An International Handbook. Oxford: Pergamon Press. 1988: 330-43.

8 Cronbach LJ, Gleser GC, Nanda H, Rajaramam N. The Dependability of Behavioral Measurements. Theory of Generalizability for Scones and Profiles. New York: Wiley, 1972.

9. Brennan RL. Elements of Generalizability Theory. Iowa City, lowa: American College Testing Publications, 1983. 

Chapter 4

Change in knowledge of general practitioners during their professional career

Y.D. van Leeuwen, S.S.L. Mol, M.C. Pollemans, M.J. Drop, R. Grol, C.P.M. van der Vleuten 


\section{Introduction}

The lotal body of knowledge of medical students increases gradually during education. 1,2 This trend is assumed to continue after graduation, due to the acquisition of knowledge related to new developments in medical science and technology. Surprisingly, however, a decrease in the total body of knowledge of certhfied doctors with increasing years of experience has been reported for $\mathrm{GPs}^{3}$ and American internists. ${ }^{4.5}$ For the internists this decline could be explained by lower scores of the more experienced (older) doctors on items concerning facts and views that had emerged in the years after their certification. ${ }^{6}$ General internists had a higher total test score than sub-specialists, while the latter scored better on the category 'new knowledge' in the field of their subspecialty. This indicates that the body of knowledge of practising physicians changes with the content of their professional occupation: knowledge relevant in the context of daily work may be revised and elaborated as opposed to knowledge that is scarcely applied. This interpretation fits well within the theory on the development of medical expertise, in which the quality of the diagnostic process is thought to be largely dependert on the frequency of patient-encounters in a certain field. ${ }^{7}$

These findings elicit a variety of additional questions about the relation between education, experience and knowledge acquisition. How does the level of knowledge reached at the end of undergraduate and postgraduate education compare with that of certified practitioners? Do changes in level of knowledge in a homogeneous group of practitioners apply equally to the whole professional domain or does this change vary for different aspects of care?

\section{Research questions and hypotheses}

In the study reported here, changes in knowledge of Dutch general practitioners have been investigated. The analyses focus on:

- the overall level of knowledge of GPs at different stages of their professional careers from the last stage of undergraduate education onwards;

- the level of knowledge for separate aspects of general practice care which are assumed to be important in the context of general practice and the professional development of GPs.

The following five aspects were thought to be of special importance:

Recent versus old knowledge: if GPs show similar results to internists, a maintained level of 'old knowledge' and a decreasing level of 'recent knowledge' with years of experience should be found. 
Knowledge related to diagnosis versus treatment: during undergraduate education the knowledge about diagnoses is paramount, whereas knowledge of the treatment of diseases is mainly acquired after graduation. This may be reflected in a more pronounced increase in scores on treatment than on diagnosis during postgraduate training. The continuous developments in pharmacotherapy may be reflected in the level of knowledge maintained after certification.

Knowledge related to serious versus not serious conditions: it is expected that knowledge about 'serious conditions" shows no decline after certification, being wital in matters of life and death.

Knowledge related to chronic versus acute illness: the surveillance of chronic illness is an important aspect of care to which the GPs devote a substantial part of their time. Students and trainees, on the other hand, have less opportunity to follow the course of chronic illness during longer periods of time. ${ }^{8}$ This may be reflected in certified GP's relatively high level of knowledge about chronic illness compared to the level of knowledge of students and trainees.

Knowledge whether or not related to Practice Guidelines: a recent development in the Netherlands, is the introduction of 'Practice Guidelines' in general practice. They reflect the state of the art on a given subject. ${ }^{9} \mathrm{It}$ is expected that trainees" knowledge about the Practice Guidelines is better than that of certified practitioners because the Guidelines are incorporated in the theoretical part of their training.

\section{Methods}

\section{Design}

This study uses a cross-sectional design. The same knowledge test was administered to groups of GPS at different stages of their professional career. Sixth year students in their undergraduate family medicine clerkship, trainees in their two year postgraduate training and GPs, both postgraduate trainers and non training GPs, participated (Table 1).

Complete groups of trainers were requested to participate as well as several groups of GPs who had registered for continuous medical education (CME-) programmes. Therefore, the GP group should be regarded as a positive selection from the total population of GPs in the Netherlands.

\section{Instruments}

The knowledge test used in this studly was at the time of this study administered to all trainees in general practice in the Netherlands three 
Table 1. Participants of the February 1992 knowledge test (N=904\%. Groups per career stage and number of individuals per group.

\begin{tabular}{lc}
\hline Participants & Number of individuals \\
\hline students & 108 \\
trainees & 445 \\
1 month in training & 85 \\
5 months in training & 103 \\
9 months in training & 46 \\
13 months in training & 55 \\
17 months in training & 99 \\
21 months in training & 57 \\
& \\
general practitioners & 351 \\
$0-5$ years of experience & 22 \\
6 - 10 years of experience & 68 \\
$11-15$ years of experience & 99 \\
$16-20$ years of experience & 109 \\
$>20$ years of experience & 53 \\
\hline
\end{tabular}

times a year during the two years of their training.* The test is designed to record progress during training and is therefore set at the level of the qualified GP. Each test consists of approximately 80 patient cases derived from daily practice with a total of 160 case-related items. ${ }^{10,11}$ The response format is of the true-false type with an additional 'I do not know' option. To discourage guessing, the final score is expressed as the percentage correct minus incorrect answers, the 'I don't know' option being disregarded. After test administration, items which are highly criticized by the participants and which have bad psychometric characteristics are eliminated. The validity and reliability of the test have been studied extensively and will be reported elsewhere (Van Leeuwen et al, under editorial review). The conclusions from these studies are, that the test has a satisfactory content and construct validity and a reliability above 80 for rankordering of groups of more than 30 individuals.

Definitions for the different aspects of care were first formulated and then tested for ambiguity. 'Recent knowledge' in this study was defined as being 5 years old or younger. Four GPs were asked to assign the items of the knowledge test to the defined categories. Consensus among all four raters determined the final selection of items for the different categories. Items for which no consensus was reached were omitted. Therefore, the

* In September 1994 the training has been extended to three years. 
number of items included in the analysis may vary for the different categories from the total number of 146 test items. Onlly 7 items were classified as "recent knowledge", which is why the mean scores on "recent" and 'old' knowledge were omitted in the analysis.

In February 1992 the knowledge test was administered to all groups of participants. The students, trainees, trainers and part of the GP non-trainers took the test under standard test conditions (supervision). Those who did not were explicitly requested not to consult the literature. The mean test score did not vary for the two conditions.

\section{Analysis}

Per group of respondents the mean score and $95 \%$ confidence interval (twice the Standard Error, SE) of the mean were computed for each set of items. Differences in item-difficulty do not allow comparison of the absolute scores on the different subtests. Therefore, only differences in mean score between career stages for every separate caregory are reported.

\section{Results}

Figure 1 shows the overall mean test score for all career stages (the vertical lines indicate $+/-2$ SE intervals).

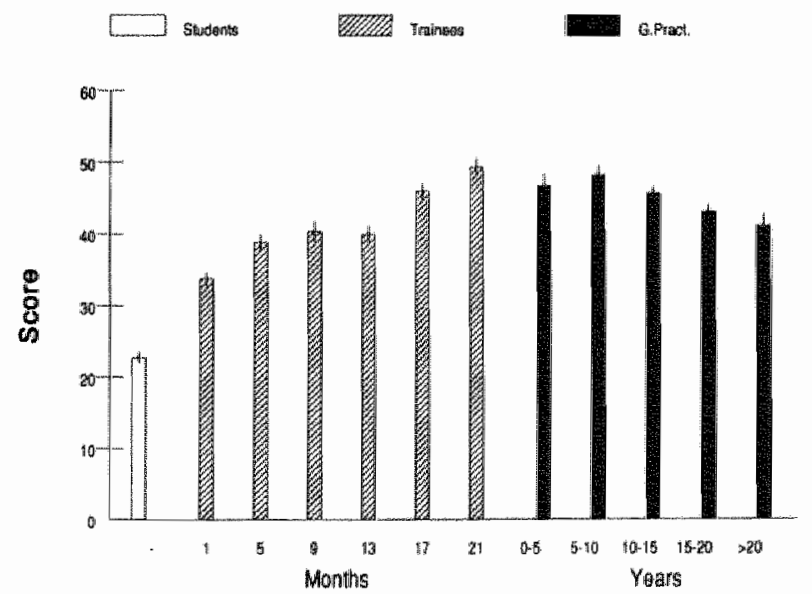

Figure 1. Total test mean score ( 146 items) -percentage correct minus incorrect- for groups of students, trainees and general practitioners $(\mathrm{N}=904)$. 


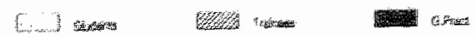

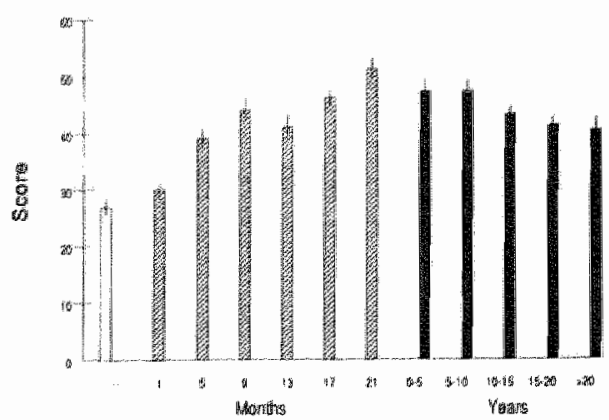

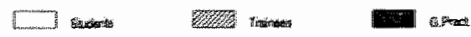

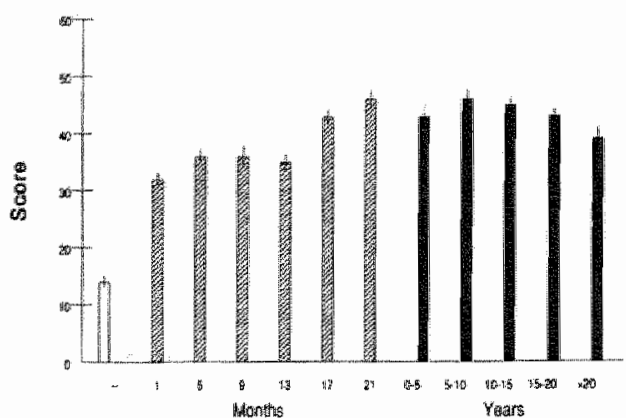

Fitgure 2. Mean score on the categories "diagnosis" (53 items) and "treatment' ( 80 items) -percentage correct minus incorrect- for groups of students, trainees and general practitioners $(\mathrm{N}=904)$.
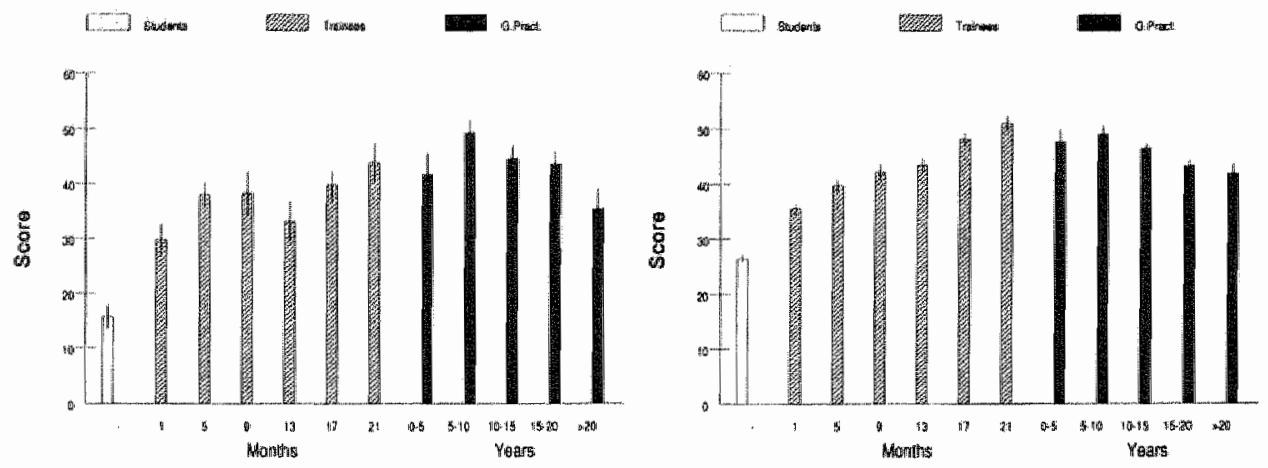

Figure 3. Mean score on the categories 'serious conditions' (15 items) and 'non serious conditions' (105 items) -percentage correct minus incorrect- for groups of students, trainees and general praclitioneris $(\mathrm{N}=904)$.

Non overlapping confidence intervals of group means indicate statistical significance. Trainees at the start of training score significantly better than undergraduate students, whereas trainees at the end of training score as high as the best scoring group of certified GPs (5-10 years after certification). During postgraduate training the scores gradually increase with the exception of a "plateau" from the fifth to the thirteenth month of training.

Figures 2 to 5 present the group mean scores and $95 \%$ confidence intervals of all groups on the different subtests. 

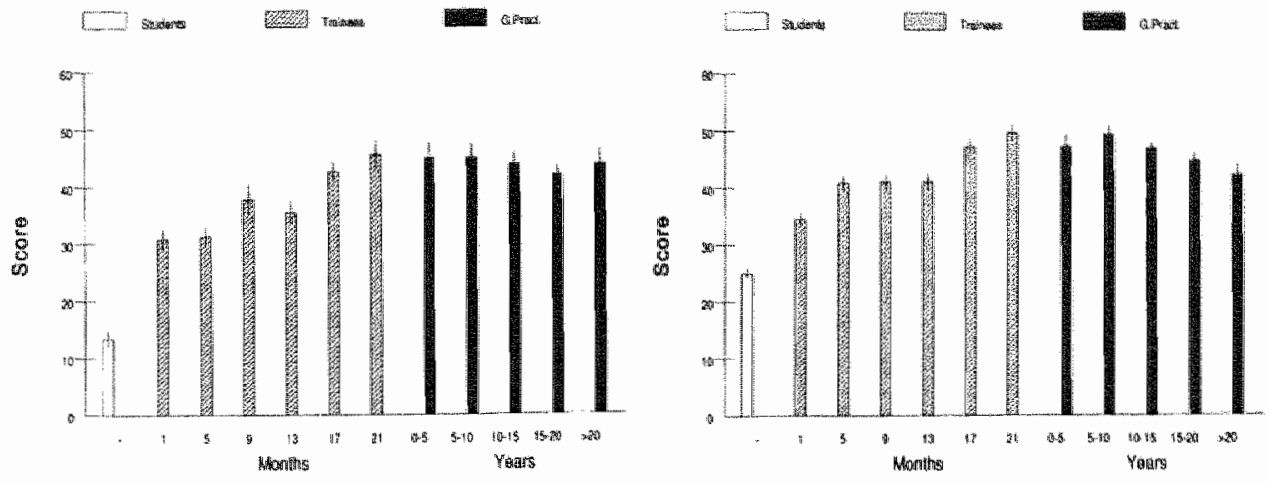

Figure 4. Mean score on the categories 'chronic illness' (30 items) and 'acute illness' (116 items) -percentage correct minus incorrect-for groups of students, trainees and general practitioners $(\mathrm{N}=904)$.
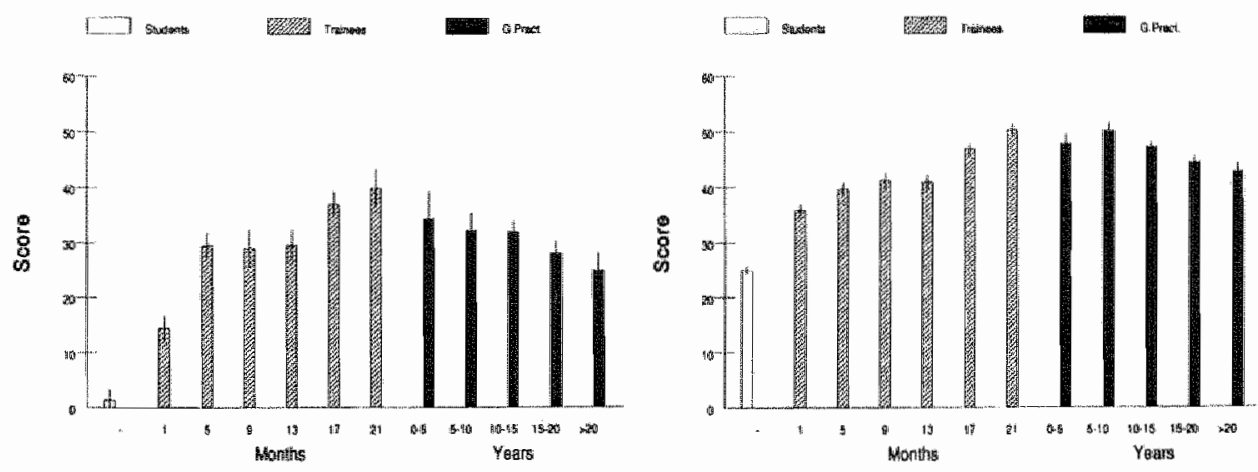

Figure 5. Mean score on "items related to Practice Guidelines' (16 jtems) and on 'items not related to Practice Guidelines' (130 items) -percentage correct minus incorrect- for groups of students, trainees and general practitioners ( $N=904)$.

There is an increase in knowledge on each of these subtests during training, all with more or less the same "plateau", whereas the curve after certification varies.

For knowledge about diagnosis as well as treatment the maximum mean score is reached at the same stage, the end of training. The increase from undergraduate to graduate level, however, is more pronounced for treatment than for diagnosis. After certification the mean scores on treatment remain more or less constant, whereas the scores on diagnosis show a slight decline.

The graply for knowledge about serious conditions shows a somewhat capricious course during postgraduate training. The top is not reached until 5-10 years after certification, followed by an evident decline. The graph 
for knowledge about non-serious conditions closely follows the course of the total test score.

The graph for knowledge about chronic diseases shows an increase during training similar to that of the total test score, followed by a 'plateau' after certification, whereas the knowledge on non chronic diseases shows a curve fairly identical to that of the total test score.

The course of knowledge about the Practice Guidelines shows a dramatic increase during postgraduate training and a considerable decrease thereafter.

\section{Discussion}

The cross-sectional design of the study does not, in fact, allow longitudinal inferences. However, terms like 'increase' and 'decrease' have been used for the sake of simplicity.

The results show that the level of knowledge of GPs during their professional career follows the same course as is demonstrated for American GPS and internists: a decline after certification. The fact that the participants possibly form a positive selection from the population of Dutch GPs strengthens this conclusion. This study shows that the decline is preceded by an evident increase in knowledge during postgraduate training resulting in a level of knowledge at the end of training that equals that of certified GPs. As far as knowledge is concerned, postgraduate training seems to contribute substantially to the competence of the recently certified practitioner. The results on the different subtests confirm this conclusion: the maximum mean score for all the different issues is reached at the end of training with the - predicted - exception of knowledge about 'serious conditions'. The maximum level of knowledge about 'diagnosis' does not precede that on 'treatment', which is counter to our hypothesis. The extent to which the different 'sorts of knowledge' are acquired or maintained after certification varies. One possible explanation is that some knowledge loses its value for daily practice. Pattern recognition based on extended experience may reduce the need of factual knowledge. ${ }^{12}$ However, there is definitely a "generation effect'. The knowledge of elder practitioners may be deficient in certain fields due to ignorance of the present-day state of the art when they were in training. Limited time for CME further explains the present findings. However, it should be kept in mind that written tests, however content-valid, may insufficiently represent the reality of daily practice, thereby putting the experienced practitioner at a disadvantage. 13

The graph for chronic diseases may indicate that the level of knowledge is related to the incidence of corresponding patient encounters. This implies that selecting patients for students and trainees may be of help to 
enhance their knowledge in a certain area. Simulated patients with, for example, serious conditions with a relatively low incidence in general practice, may play a role in the maintenance of the competence of certified GPs.

In general we may conclude that studying the changes in the level of knowledge of medical professionals during their life-long career, is of value to the development of theories on knowledge acquisition as well as to curriculum planning for postgraduate training and $\mathrm{CME}$.

A longitudinal study might well have additional value but does not seem feasible, given the fact that it would take thirty years or more to accomplish. Further research should concentrate on facilitating and impeding factors for the acquisition of knowledge before and after certification:

\section{References}

1 Van der Vleuten C, Verwijnen M. A system for student assessment. In: Van der Vleuten $\mathrm{C}$, Wijnen $\mathrm{W}$, editors. Problem-based leaming: Perspectives from the Maasiricht experience. Amsterdam: Thesis, 1990:27-49.

2 Keane DR, Blake JM, Norman GR, Mueller CB. Introducing progress testing in a traditional problem-based curriculum: psychometric properties. Suppl Acad Med, (in press).

3 Leigh TM, Young PR. Haley JV. Performances of family practice diplomats om successive mandatory recertification examinations. Acad Med 1993; 68:912-9.

4 Meskauskas JA, Webster GD. The American Board of Internal Medicine Recertification Examination: process and results. Ann Int Med 1975; 82: 577-81.

5 Norcini JJ, Lipner RS, Benson JA, Webster GD. An analysis of the knowledge base of practicing internists as measured by the 1980 recertification examination. Ann Intern Med 1985; 102: 385-9.

6 Day SC, Norcini J., Webster GD, Viner ED, Chirico AM. Th effect of changes in medical knowledge on examination performance at the time of recertification. In: Proceedings of the $27 \mathrm{th}$ Annual Conference on Research in Medical Education. Chicago, Illinois: Association of American Medical Colleges, 1988: 139-144.

7 Norman G, Allery L, Berkson L, et al. Research in the psychology of clinical reasoning: implications for assessment. In: Jolly B, editor. New Directions in the Assessment of Clinical Competence. Proceedings Cambridge Conference IV. 1989. Cambridge: Cambridge University Press (in press).

8. Lamberts $\mathrm{H}$, Ouwehand $\mathrm{G}$. Een arts-assistent in cen huisartspraktijk. Her werk en de plaats van de arts-assistent in opleiding gekwantificeerd. Huisarts Wet 1982 ; 25: 4-10.

9 Rutten GEH, Thomas S, redactie. NHG-Standaarden voor de huisarts. Utrecht: Bunge/NHG, 1993.

10 Kramer AWM, Pollemans MC. Nation-wide progress test assessing knowledge in vocational training for general practice. In: Bender W. Hiemstra RL. Scherpbier AJJA, Zwierstra RP, editors. Teaching and Assessing Clinical Competence. Groningen: BoekWerk Publ, 1990: 280-2. 
11 Van Leewen $Y \mathrm{D}$, Van Hessen PAW. Clinical competence and objective questhons: lactics to realize a true/false fomat assessing competence. In: Bender W, Memstra RL, Scherpbier AJJA, Zwierstra RP, editors. Teaching and Assessing Clinical Competence. Groningen: Boek Werk Publ, 1990: $233-6$.

12 Fellowich PJ, Barrows HS. Issues of generality in medical problem solving. In: Schmid $\mathrm{HG}_{3}$, De Volder $\mathrm{ML}_{\text {." }}$ editors. Tutorials in problem-based learning; a new direction in teaching the health professions. Assen: wan Gorcum, 1984: 128-42.

13 Rethans JJ, Siurmans F, Drop R, Van der Veuten C. Assessment of the performance of general practitioners by the use of standardized (simulated) patients. Br IGen Pract 1991:41: 97-9. 
Chapter 5

\section{Does the time spent by trainers on education influence the growth in knowledge of trainees in general practice?}

Y.D. van Leeuwen, S.S.L. Mol, C.P.M. van der Vleuten, R. Grol, M.J. Drop, H. Diusman 


\section{Summary}

In the context of postgraduate training for general practice a study has been performed to investigate the time spent by the GP-trainer on educational encounters with his trainee.

The research questions related to the actual time spent on educational encounters between trainer and trainee, factors that might influence this time-investment and the relation of time spent on education with the growth in knowledge of the trainee.

Two written knowledge tests were taken by 58 trainees, the 'pre-test' shortly after the start of training, the 'post-test' eight months later. Questionnaires relating to trainer and practice features were completed simultaneously. Time spent on nine different types of educational encounters was registered by the trainees in minutes per encounter during twelve days in total in the fourth and sixth month of the training.

To explore whether some educational activities were mutually related in terms of devoted time a Principle Component Analysis was conducted, followed by a varimax rotation. Two factors, explaining $45 \%$ of the variance, emerged which were entitled: "patient-centred' and 'traineecentred' activities, representing the major concern of the trainer. Pearsons correlations were calculated for the relation of the two factors and the total time spent on education with the trainer and practice features as assessed by the questionnaires. The relation between the time spent on education and the growth in knowledge of the trainee was assessed in a multiple regression analysis with the post-test as dependent variable and the two factors as well as the pre-test as independent variables. The actual time spent on educational encounters varied considerably for the trainer-trainee pairs and showed no relation with trainer variables such as experience as GP or as a teacher nor with practice variables such as daily workload and practice organization. A relation between the lime spent on educational encounters and the growth in knowledge of the trainee could not be demonstrated.

\section{Introduction}

Participation in patient care forms the core element of postgraduate training for general practice. Courses and seminars, however valuable, cannot replace patient encounters and daily practice activities. Nevertheless, mere practice experience is insufficient to attain a required level of competence. Reflection on the actual performance is essential. Supervision by an experienced general practitioner is provided to stimulate this reflection and to facilitate learning. The role of the trainer-supervisor is to help the trainee 
to elicit 'common rules' from a variety of experiences and to enlarge the understanding of his/her own capacities and deficiencies.

In the UK and the Netherlands, where postgraduate training for general practice is well developed, "the trainer is supposed to spend at least one hour a day on supervision. A considerable part of this time is supposed to be devoted to evaluation of the trainee's patient encounters, mexting the trainee's needs for advice and for assessment of the quality of the care she provided. The trainer should, however, reserve time for other educational activities, such as observation of the trainee, tutorials on specific themes like diabetes and palliative care, and evaluation of the trainee s progress. 2,3 These interventions, on first sight not conditional for the quality of the daily patient care, require a more active role of the trainer: they have to be planned and prepared. Trainers receive special training in supervision and they are regulary encouraged to vary their educational methods. Their adherence to the recommendations for good trainer performance, however, in terms of the actual time spent on the various educational methods, has seldom been systematically investigated. 4,5 The same applies to the influence of factors such as workload, trainer's experience and the trainertrainee interaction on the time spent on education. Several studies have demonstrated a positive relation of the time devoted by the trainet to supervision with the trainee's satisfaction with the training as a whole, 7,8 but the relation with the trainee's competence has only marginally been explored. 9

This study explores, firstly, the actual amount of time spent on education in the training practice, secondly, its relation with a number of potentially influencing factors (relating to workload, the trainer's experience and his professional attitude) and thirdly, its rellation with the trainee's growth in knowledge.

\section{Methods}

\section{Context of the study}

At the time of this study training in general practice in the Netherlands required wo years and consisted of three periods of approximately eight months each. * The first and third period of eight months are spent in a general practice, the second period in hospitals and other medical institutions. During the entire training period one day a week is reserwed for seminars, group discussions etc., the so-called "day release courses".

* In September 1994 the training has been extended to three years, the three periods each being prolonged to 12 monthis. 
This study focuses on the first period of eight months. All 85 trainees who started training in January 1992 in the Netherlands as well as their urainers were requesued lo participate.

\section{Instruments}

Three instruments were used, the first to assess the time spent on education in practice, the second the trainee's knowledge and the third trainer and practice variables.

Time spen on education by the trainer-trainee pairs was assessed by means of the logbook merhod. This method is commonly used to register types and frequency of patient encounters. ${ }^{10.11}$ In this study the logbook required registration of educational encounters between trainer and trainee. The logbook contained a completion instruction and a number of logforms, one for each registration day. The nine types of educational trainertrainee encounter to be registered were precoded and defined on the instruction page (Figure 1).

1. The trainer observes the trainee's performance during surgery, home visits, or special proceedings like a surgical intervention.

2. Trainer and trainee review the trainee's patient encounters. Questions about a specific case/problem as well as the justification of the trainee's diagnosis, treatment and approach to the patient are discussed.

3. A topic is discussed in clepth. Trainee and trainer prepare this session by studying the literature and preferably by collecting related patient cases. Examples are: the use of antibiotics on the management of diabetes.

4. The trainee consults the trainer during surgery, whenever thought desirable. (N.B. this category does not refer to consultations initiated by the trainer).

5. The trainee observes the trainer during surgery, home visit or special performances.

6. The trainer discusses his own patient encounters with the trainee.

7. Tranee and trainer evaluate the competence acquired by the trainee during the preceding timespan. The professional growth is analysed and facilitating and impeding factors for the learning process are discussed. The teamwork is assessed.

8. a. Topics of whatever nature that spontaneously emerge are discussed.

b. Trainer and trainee assist each other in complex situations, for example with resuscitation. The learning is of secondary imporiance here.

9. Miscellaneous activities. For example, presence at team discussions (with paramedical workers or specialists).

Figure 1. Description of nine types of educational trainer-trainee encounters.

The logbook was a modification of an earlier version which had been assessed on clarity of instruction and on feasibility. ${ }^{5}$ The reliabillity of the instrument is reported in detail elsewhere. ${ }^{2}$ It was concluded that the 12-day registration-period provided sufficiently reliable information. 
The knowledge of the trainee was assessed by a written test assessing knowledge relevant for daily patient care. This test is routinely administered to all trainees in general practice in the Netherlands six times during their training period..$^{13}$ It consists of about 80 patient problem descriptions commonly presented to the general practitioner. The items, 160 in total, focus on the key features of the problem. ${ }^{14}$ Themes are selected on the basis of a blueprint, established by consensus within the profession. ${ }^{15}$ The test has a progress-testing format, 16 implying that, (a) the test is set at the level of the qualified general practitioner at the moment of certification, (b) successive tests are similar in format but vary in content, and (c) all trainees take the same test regardless of their training level. Progress during training can accordingly be monitored. The response format of the test is of the true-false-type with an additional. "I don "t know" option. The final score is expressed as the percentage correct minus incorrect answers. The reliability of the test $(\alpha)$, is above 80 for groups of more than 20 individuals and between .70 and .75 for individuals ( $V$ an Leeuwen et al, under editorial review).

Trainer and practice features were measured by questionnaires. Items were included concerning the trainer's experience as general practitioner and supervisor, as well as his workload and practice organization. Items were scored on an ordinal (yes/no) and a ratio scale (e.g. number of patients). The trainee's ratings of the trainer, 9 items, scored on a five-point Likert scale, were aggregated by computing a sum score $(\alpha>80)$. The same was done for the trainer"s rating of the trainee (7 iterns) $(\alpha>80)$.

\section{Procedure}

The first knowledge test was administered to all participants one month after the start of training (pre-test), the second test eight months later (post-test), both under standard test conditions. The two tests were equated using a horizontal linear equation procedure with a set of common items (20\% of the test items) as anchor test. ${ }^{17}$ The questionnaires were administered simultaneously with the tests.

The type and duration of all trainer-trainee contacts were registered in the fourth and sixth months of training, during twellve working days in total.

\section{Analysis}

The overall time spent on education per day for each trainer-trainee couple was computed as well as the time per day spent on each of the separate activities. The group mean scores and standard deviations were calculated. In order to explore whether some educational activities were mutually related in terms of devoted time a Principal. Component Analysis was 
conducted, followed by a varimax rotation. A two factor solution, explaining $45 \%$ of the variance, was chosen, because it was theoretically best understood: the selection of items of both factors (cut-off score .40) reflected the trainers principle concern: either the quality of patient care provided by the trainee, or the trainee's professional growth. The two dimensions were entitled I: 'patient-centred' (items 2, 6, 8, 9), and II: 'trainee-centred' (items 1, 3, 4, 5, 7).

In order to identify relevant determinants for the time spent on educational encounters, Pearson correlation coefficients were computed between the questionnaire items and the time in minutes per day: Factor I and Factor II scores as well as all educational encounters in combination minus informal meetings.

In order to assess the relation between time spent on educational encounters and the trainee's growth in knowledge, a stepwise multiple regression analysis was used with the post-test knowledge score as the dependent variable and the two factors scores as well as the pre-test score as independent variables. The pre-test score was included in order to correct the variance in post-test scores for the variance in pre-test scores, thereby introducing 'growth in knowledge' as the actual dependent variable. $^{18}$

\section{Results}

All 85 trainees took both knowledge tests. 58 of them completed the logbook and questionnaire (response $68 \%$ ). Respondents did not differ significantly in mean test score on the pre-test nor on the post-test $(\mathrm{T}=$ -1.74 resp. -.59 , df $79 ; \mathrm{p}>.05$ ) from the non respondents. Table 1 presents mean score and standard deviation, minimum and maximum score in minutes per day for each of the types of trainer-trainee encounters and the relative contribution of each type of encounter to the total time spent on education.

The total time spent on education per day is on average more than one hour with a standard deviation of about 5 minutes. The minimum is about one quarter of an hour and the maximum more than three hours! Time spent on informal meetings accounts for nearly a quarter of the time. The time devoted to 'patient-centred' educational activities (items $2,6,8,9$ ) is three times as much as time devoted to 'trainee-centred' educational activities (items $1,3,4,5,7)$ and accounts for nearly $70 \%$ of the time spent on education. 'Evaluation of the trainee's patient encounters' (mean 24 minutes) receives the highest score, constituting with 'informal meetings' the set of activities that occurs in every practice. 
Table 1. Time spent on trainer-trainee encounters: mean time per day (minutes), standiurd deviation (sd), minimum and maximum time, and percentage of the cotal time spent on educational encounters per day.

\section{Minutes per day}

Type of trainer-trainee encounter

mean $\quad$ sd $\quad \min \quad \%$

1. observation of the trainee"s

patient encounters

4.0

4.9

0.0

29.8

5.5

2. evaluation of the trainee $" s$

patient encounters

3. theme discussion

4. consultation of the trainer

5. observation of the trainer's

patient encounters

\section{0}

10.6

1.1

49.8

36.3

6. evaluation of the trainer's patient encounters

7. evaluation of progress

8. informal meeting/mutual assistence

9. miscellaneous

Table 2 shows the bivariate correlations between the questionnaire variables and the time spent on educational activities.

Of the trainer variables only the trainer's range of educational experience shows a significant correlation (.28) with the time spent on (patientcentred) educational encounters. It is noteworthy, that none of the items related to workload and practice organization are correlated with time spent on education. Significant positive correlations do appear for the trainer's and trainee's ratings. Higher ratings for the trainee correspond with more patient-centred encounters (.33), whereas higher ratings for the trainer correspond with more trainee-centred educational encounters $(.40)$ and with more educational encounters in general $(.40)$.

Table 3 presents the results of the multiple regression analysis. The analysis shows that only the pre-test score contributes significantly to the explanation of variance in post-test scores. Approximately $21 \%$ of the variance in the post-test scores is explained by the pre-test scores. 
Table 2. Pearson Correlation Coefficients (r) between trainer and practice wariables and the time spent on education represented by: the total time on education minus informal meetings (total), Factor I (patient-centred) and Factor II (trainee-centred) loading (N trainer-iramee pairs $=58)$.

\begin{tabular}{|c|c|c|c|}
\hline Variables & Total & Factor I & Factor II \\
\hline \multicolumn{4}{|l|}{ Tratiner wariables } \\
\hline number of trainees trained & -.20 & -.12 & -.08 \\
\hline $\begin{array}{l}\text { range of experience in different } \\
\text { educationat setings }\end{array}$ & .19 & $.28 *$ & -.04 \\
\hline (under/postgraduate, CME) & 13 & 20 & .04 \\
\hline - years of experience in different & & & \\
\hline educational settings & -.20 & -.24 &.- .03 \\
\hline postgraduate training performed & .12 & .06 & .14 \\
\hline years of experience as a $\mathrm{GP}$ & .06 & .08 & .03 \\
\hline \multicolumn{4}{|l|}{ Workload/practice variables } \\
\hline \multicolumn{4}{|l|}{ - trainer's number of patient } \\
\hline encounters per day & -.08 & -.01 & -.07 \\
\hline trainees number of patient & & & \\
\hline encounters per day & .11 & .14 & .08 \\
\hline - practice organization $(0=$ group, $1=$ solo $)$ & -.14 & -.14 & -.12 \\
\hline - urbanization practice area & .07 & .03 & .05 \\
\hline \multicolumn{4}{|l|}{ Ratings } \\
\hline - trainer"s rating of treninee & .20 & $33^{*}$ & -.04 \\
\hline - trainee's rating of trainer & $.40^{*}$ & .18 & $.40^{*}$ \\
\hline
\end{tabular}

* = significant $(p<0.05)$

Table 3. Multiple regression analysis with the post-test as dependent variable and Factor I and Factor II as well as the pre-test as independent variables: cumulative percentage of explained variance ( $R$-square), parameter estimate (b) and standardized estimate $(\beta)(N=58)$.

\begin{tabular}{llll}
\hline Variables & R-square & $b$ & $\beta$ \\
\hline pre-test & .21 & .51 & $.45^{*}$ \\
Factor I: patient-centred & .21 & -.75 & -.07 \\
Factor II: traineemcentred & .21 & -.34 & -.03 \\
\hline
\end{tabular}

* = significant $(p<0.05)$ 


\section{Discussion}

The finding that the average time spent on education in practice per day is more than one hour is reassuring. Even if the time spent on 'informall meetings" is substracted, the mean nearly meets the standard of one hour. The standard deviation and range, however, are substantial.

The co-operation of trainer and trainee in patient care seem to imply daily evaluation of the trainee's patient encounters and informal meetings. These activities require nearly three quarters of the time spent on education at the cost of encounters where the trainee's professional development is of central interest. The average score for 'observation of the trainee" hardly represents the time required for the observation plus feedback of one consultation per week. On the other hand, the average time for 'theme discussion' and 'evaluation of progress' seems acceptable, allowing a session of one hour per month for either activity.

The substantial variation in time spent on educational activities raises the question of the factors involved. From this study it may be concluded that neither the trainer's educational or professional experience nor the workload and practice organization have an influence of any importance on the time spent on education.

The bilateral ratings of trainer and trainee are in theory important indicators of the educational 'climate', and therefore potentially related to time spent on education. The empirical data seem to confirm this. The best performing trainers, according to the trainees, are those who spend relatively a lot of time on 'trainee-centred' activities. Conversely, higher ratings for the trainee correspond with more 'patient-centred' activities. Further analysis indicates that the appreciation between trainer and trainee is seldom mutual ( $r=18$; not significant), which is in itself a significant finding. It seems that the trainees generally appreciate the trainer who is concerned with their professional development, whereas the trainers appreciate the trainee who allows them to concentrate on activities related to daily patient care.

The multiple regression analysis provides a different perspective on the importance of time spent on education: there is no relation with the growth in knowledge of the trainee. Further exploration of the data does not show a curvilinear relation. The quantity of educational encounters seem to be irrelevant to the growth in knowledge of the trainee. This is counter to our expectations and obviously also to those of the training institutes, given their attachment to guidelines for time spent on education.

The quality of the trainer's education has not been investigated in this study. However, further analysis of the data show no relation between the quality of the trainer as supervisor as perceived by the trainee and the growth in knowledge. 
Furthermore, it should be noted that growth in knowledge was our only outcome measure; the trainee's skills, attitude, motivation and workingstyle have so far not been taken into account. This does not, however, devalue the importance of this study. The acquisition of knowledge is one of the major goals of postgraduate training. Moreover, the rellation between knowledge and medical expertise ${ }^{19}$ has been theoretically outlined and empirically confirmed: knowledge appears to be the most essential element of medical expertise. In addition, correlational studies show that knowledge test scores at graduation predict future performance fairly well. ${ }^{20}$

The fact that a relation between time spent on education and growth in knowledge is absent raises the question whether the acquisition of knowledge is more a 'trainee affair' than was assumed. The extensive contribution of the pre-test score to the variance in post-test scores strengthens this assumption. Personal characteristics, motivation and learning style might be even more important than was assumed. ${ }^{9}$

\section{References}

1 Boerma WGW, de Jong FAJM, Mulder PH. Health care and general practice across Europe. Utrecht: NIVEL/NHG, 1993.

2 Pereira Gray DJ. Training for general practice. London: Butler \& Tanner Ldd, 1982.

3 Van Geldorp $\mathrm{G}$, editor. Opleiden en leren in de huisartspraktijk. [Training and learning in general practicel. Utrecht: Bunge., 1985.

4 Bulte J, Tielens V, Visser S, van der Ende J, Groenier K. De opleiding tot huisarts

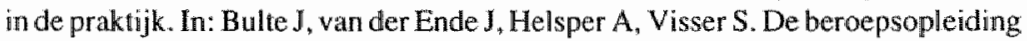
tot huisarts [Training for general practice]. Groningen/Nijmegen: KUN, 1988.

5 Stolk J, Tan LHC. Opleidingscontacten in de huisartspraktijk [Educational encounters in general practice]. Bulletin Medisch Onderwijs 1992; 11: 62-6.

6 Ronalds C, Douglas A. Pereira Gray D, Selley P. Fourth National Tramee Conference. Report, Recommendations, and Questionnaire. [Occasional Paper 18]. London: Royal College of General Practitioners, 198 \#.

7 Farmer E, Taylor S. Assessment of teaching by family medicine programme vocational trainees. Aust Fam Physician 1990; 19:549-57.

8 Kelly DR, Murray TS. An assessment of vocational training. Med Educ 1992; 26 : 402-5.

9 Freeman J, Roberts J, Metcalf D, Hillier V. The influence of trainers on trainees in general practice. [Occasional paper 21]. London: Royal College of General Practitioners, 1982.

10 Hobbs J, Mongan P, Miller MD. A system for assessing clerkship experience using a logbook and microcomputers. Family Medicine; 4: 287-90.

11 Luke C, Kadzombe E, Gorman D. Armstrong A. An evaluation of a logbook for trainees in accident \& emergency medicine in the United Kingdom: senior consultant opinion. Archives of Emergency Medicine 1993; 10: 43-7. 
12 Van der Vleuten CPM, Van Leeuwen YD, Mol SSL, Dusman H, Tan LHC, Grol R. Betrouwbaarheid wan onderwijsregistraties in praktijkstages [Reliabiliry of educational registrations in practical training periods]. In: Houtkoop E, Pols J, Pollemans MC, Scherpbier AJA, Verwinen GM, editors. Gezond Onderwijs III. 's Gravenhage: Haagse Hogeschool, 1994.

13 Kramer AWM, Pollemans MC. Nationwide progress test assessing knowledge in wocational training for general practice. In: Bender W, Hemstra RJ, Scherpbier AJJA, Zwierstra PR, editors. Teaching and Assessing Clinical Competence, Groningen: Boek werk, 1990.

14 Bordage G, Page G. An alternative approach to PMPs: the "key features" concept. In: Hart IR, Harden RM, editors. Further Developments in Assessing Clinical Competence. Montreal: Heal Publications, 1987.

15 Pollemans MC. Kennistoetsing bij huisartsen [Knowledge testing for general practitioners]. [Dissertation]. Maastrichi: Datawyse/University Press Maastricht, 1994.

16 Van der Vleuten CPM, Verwijnen M. A system for student assessment. In: Van der Vleuten $C$, Wijnen W, editors. Problem based learning: Perspectives from the Maastricht experience. Amsterdam: "Thesis, 1990.

17 Crocker L, Algina J. Introduction to Classical and Modern Test Theory. Orlando: Holt, Rinehart and Winston, 1986.

18 Cronbach LJ. How we should measure change - or should we? Psychol Bull 1970; I: $68-80$.

19 Norman G, Allery L, Berkson L, et al. Research in the psychology of clinical reasoning: implications for assessment. In: Jolly $B$, editor. New Directions in the Assessment of Clinical Competence. Proceedings Cambridge Conference IV. Cambridge: Cambridge University Press, 1989.

20 Norman $\mathrm{G}$. Can an examination predict competence? The role of recertification in maintenance of competence. Annals RCPSC 1991: $2: 121-4$. 

Chapter 6

\section{Factors influencing the growth in knowledge of trainees in general practice}

Y.D. van Leeuwen, H. Düsman, S.S.L. Mol, M.J. Drop,

R. Grol, C.P.M. van der Vleuten 


\section{Introduction}

In the UK, the Netherlands and some of the Nordic countries postgraduate training for general practice has a long tradition. Despite differences in structure and content of the curriculum, there is considerable similarity. 1,2 In most countries trainees work and learn in general practice under the supervision of a GP trainer for a substantial part of the time. Gradually the trainer has evolved from "host" to "teacher' and 'role model' 3,4 ; the theoretical curriculum - courses and seminars - has become well elaborated and increasing attention is paid to formal assessment of the trainee's competence and performance. ${ }^{5,1,6}$ As is often the case in education, reforms in structure and content of the training have mainly been based on perceived shortcomings in the prevailing system and hardly on outcomes of evaluative research. ${ }^{7}$

Literature search of studies on the outcome of postgraduate training in general practice in relation to the input yields only two publications that provide relevant information. In the UK Freeman et al. ${ }^{8}$ demonstrated a significant influence of the trainer's competence on the growth in competence of the trainee, measured by written tests. This would argue for a selection of trainers on the basis of their competence. In the Netherlands Grol et al. ${ }^{9}$ produced evidence that a more structured theoretical curriculum provides better outcome in terms of competence and performance. However, neither of these studies reckon with the interaction of the different components of the practical and theoretical curriculum, such as trainer and practice or faculty and theoretical curriculum. As a result, their relative contribution to the outcome in terms of the trainee's competence remains unclear and questions relevant for further development of the training remain unanswered. Should the training of the trainers be intensified? Should the theoretical curriculum be elaborated further? Should the trainer be encouraged to spend more time on educational encounters with the trainee? Should the selection of practices, trainers and trainees be more rigorous? An answer to these questions would enable faculty to establish priorities and to improve the effectiveness of their interventions. In this study the relative contribution of the different components of the training to the outcome in terms of the trainee's clinical knowledge - one of the major goals of postgraduate training and one of the essential elements of medical expertise ${ }^{10}$ - is explored. 


\section{Methods}

\section{Context of the study}

Postgraduate training for general practice in the Netherlands has a uniform structure and a nationally endorsed curriculum. The departments of general practice of the eight faculties of medicine in the Netherlands, in the context of postgraduate training usually addressed as 'training institutes', are responsible for the organization of the training. The main differences between institutes lie in the content of the 'day-release courses': seminars, group discussions and skills training, organized for groups of trainees.

The training - two years until September 1994 and since than three years - consists of three blocks of equal length. The first and last period are spent in general practice, the second in hospitals and other medical institutions. During the whole training period one day a week is reserved for day release courses and one half day a week for self-directed learning. This study focuses on the outcome of the first training period.

\section{Instruments}

Knowledge was assessed by a written test that measures knowledge relevant to daily patient care. This test is routinely administered to all trainees in general practice in the Netherlands at fixed intervals during the whole period of their training. ${ }^{11}$ It consists of about 80 patient cases as they are usually presented to the general practitioner, each followed by one or more test items. The items - 160 in total - focus on the 'key features' of the problem. ${ }^{12,13}$ Test content is selected on the basis of a blueprint, established by consensus among general practitioners. ${ }^{14}$ The test has a progress-testing format, implying that (a) the test is set at the level of the qualified general practitioner at the moment of certification, (b) tests of similar format but different content are periodically administered, and (c) all trainees take the same test regardless of their training level. Progress during training can accordingly be monitored. ${ }^{15}$ The response format of the test is of the true-false-type with an additional 'I don't know' option. The final score is expressed as the percentage correct minus incorrect answers.

The components of the training to be investigated are described in several publications on postgraduate training for general practice in the Netherlands, ${ }^{16,17}$ and represent the primary sources for the learning of the trainee: daily patient encounters, trainer as role model and supervisor/teacher, training practice, theoretical curriculum, staff and self-directed learning. Trainee and trainer features as well as the components of the training were measured by questionnaires. Items referred either to facts (e.g. the practice equipment) or to perceived quality (e.g. the trainees 
evaluation of the trainer as a teacher). The items on features of the trainer and the training practice were derived from literature. 18-20,8,21-24 Trainer items reflected the trainer's quality as a teacher/supervisor (e.g. motivation for teaching, approachability, clarity of instruction) and as a GP (e.g. motivation, level of knowledge, approach of patients). Practice items reflected a.o. the practice organization and practice facilities. The items required a "yes" or 'no' answer, or used a five-point Likert scale, ranging from 'totally disagree' to 'totally agree' or from 'unsatisfactory" to 'excellent'. For some clusters of items (e.g. items referring to the perceived quality of the trainer as GP) a sum score was computed. The internal consistency $(\alpha)$ of all of these clusters was more than .80 . The theoretical curriculum was represented by the variable 'training instinute'. The trainee"s overall satisfaction with trainer, practice, theoretical curriculum and faculty was rated on a scale from $\mathbb{1}$ to 10 .

Time spent on education by the trainer-trainee pairs was assessed by means of a logbook. ${ }^{25,26}$ All trainer-trainee encounters with an educational purpose were registered by the trainee in minutes. The logbook used in this study contained a written instruction for completion and preprinted pages, one for each registration day. The types of educational trainee-trainer encounters to be registered were precoded and defined on an instruction page (Van Leeuwen et al, under editorial review).

\section{Procedure}

At seven training institutes a group of 12-13 trainees started their training in January 1992. All these trainees and their trainers, 85 pairs, agreed to participate in the study. All were asked to take two knowledge tests, the 'pre-test' one month after the start of training and the 'post-test' shortly after the end of the first training period in general practice, eight months later. The tests were taken under standard test conditions. Questionnaires were completed after each test administration. In the fourth and sixth months of training the trainees completed the logbook registration during a total of 12 days.

\section{Analysis}

The analysis aimed at relating the increase of the trainee's score on the knowledge test to training, trainer and trainee variables as expressed in the questionnaires, to the trainer's knowledge tesi score and to the registration of time spent on education. To allow correction for test difficulty the two knowledge tests were equated using the horizontal linear equation procedure with a set of common items (approx. 20\%) as "anchor test". ${ }^{27}$

Time spent on education as registered with the logbook method was recorded as the mean time per individual in minutes per day. In order to 
investigate the univariate relation between the training variables and growth in knowledge, questionnaire items, as well as total time spent on eclucation and trainer's knowledge score were correlated with trainee"s pre- and post-test score (zero order correlation). In order to assess the relation of these variables with 'growth in knowledge " the first order partial correlations were computed between these variables and the post-test score, controlling for the pre-test score. To correct for interactional effects between variables, the multivariate association was estimated of the posttest score with all independent variables in combination. In this analysis the pre-test score of the trainee was included as independent variable allowing correction of the explained variance in post-test scores for the variance in pre-test scores. Consequently, "growth in knowledge' was the actual dependent variable. 28 The pre-test score was the only variable introduced as 'fixed". The remaining items were entered stepwise to determine their additional contribution to variance in growth in knowledge. In order to allow analysis on nominal variables, such as gender and training institute, these variable values were transfomed to dummy variables in accordance with standard regression procedures. ${ }^{29}$

\section{Results}

Complete data on all instruments were available for 58 trainer-trainee pairs. Only these were introduced in the analysis. Missing values were found predominantly for the questionnaire and logbook items. The mean pre-test and post-test score on the knowledge test for those who completed all instruments and those who did not, did not differ significantly $(\mathrm{T}=$ -1.74 resp. $-0.59 ;$ df $79 ; p>0.05)$. The trainees" mean score on the pre-test was 35.4\% (sd 9.0) and 47.0\% (sd 10.3) on the post-test. The difference is statistically significant $(T=-8.20 ;$ df $57 ; p<0.05$ ) The mean score of the trainers remained constant, $45.2 \%$ (sd 11.7 ) versus $45.7 \%$ (sd 9.5). The reliability coefficients $(\alpha)$ of the pre-test and post-test for individuals were .70 and .73 respectively.

Table 1 presents the training institutes rank-ordered according to the differences in mean score between pre-test and post-test.

Five of the seven training institutes - representing different theoretical curricula - show a considerable and significant increase in mean test score, whereas two do not.

Table 2 presents descriptive statistics, the univariate associations (Pearson's r) between the independent variables and the pre-test and post-test score and the partial correlations. 
Table L. Jiances" mean pre- and positest scores (equated) $\left(M\right.$ pr $M_{p o}$ ) and $95 \%$ confidence interval (Cl) as well ats the growth scores for each of the seven training institutes $\left(M_{p o}-M_{p r}\right)$.

\begin{tabular}{|c|c|c|c|c|c|c|}
\hline \multirow[t]{2}{*}{ Instillule } & \multirow[t]{2}{*}{$N$} & \multicolumn{4}{|c|}{ Mean testscores (\% correct minus incorrect) } & \multirow{2}{*}{$\frac{\text { Growth score }}{\mathrm{M}_{\mathrm{po}}-\mathrm{M}_{\mathrm{pr}}}$} \\
\hline & & $\mathrm{M}_{\mathrm{pr}}$ & $\mathrm{Cl}$ & $\mathrm{M}_{\mathrm{po}}$ & $\mathrm{Cl}$ & \\
\hline A & 6 & 29.8 & $27.2-32.4$ & 43.4 & $39.0-47.8$ & 13.6 \\
\hline $\mathrm{B}$ & 9 & 32.7 & $31.2-34.2$ & 46. & $44.0-48.2$ & 13.4 \\
\hline $\mathrm{C}$ & 7 & 411.2 & $36.0-46.4$ & 54.5 & $51.0-58.0$ & 13.3 \\
\hline$D$ & $\|$ & 32.0 & $29.6-34.4$ & 45.1 & $41.4-48.8$ & 13.1 \\
\hline $\mathrm{E}$ & 10 & 37.6 & $34.8-40.4$ & 49.6 & $46.6-52.6$ & 12.0 \\
\hline F & 9 & 37.4 & $33.8-41.0$ & 43.5 & $40.1-46.9$ & 6.1 \\
\hline $\mathrm{G}$ & 6 & 37.6 & $35.3 \cdot 39.9$ & 41.9 & $37.0-46.8$ & 4.3 \\
\hline
\end{tabular}

The average number of patients seen by the trainee each day is 21 , which meets the (informal) standard of 20-30 patients.

The mean scores within the category the trainer as general practitioner show a mean number of years of experience as GP of 15 years. The mean time reported for study of the literature is 2.5 hours a week, for Continuing Medical Education (CME) half a week a year. Nearly half of the trainers participate in audit groups on a regular basis. The mean score for the trainee's appreciation of the trainer as GP (5 items) is 19.0 (range 5-25). The variation is small (sd 2.8).

The third section shows the trainer"s performance and experience as supervisor. The average time spent on educational activities in practice is more than one hour per day, with a large standard deviation (half an hour). The trainer"s average number of trainees previously supervised, the present trainee included, is 5. The standard deviation of 4.4 indicates that there is a wide variation in 'experience as a trainer'. On average the trainer has seven years of experience in education (either pregraduate or postgraduate). The mean score for the trainee's appreciation for the trainer as supervisor (4items) is 14.9 (range 4-20) with a standard deviation of 3.4 , which means that most trainers are rated as 'satisfactory'. In the category training practice the mean score for the equipment is 11.9 (range 0-47), with a standard deviation of 3.8 , implying that most training praclices lack certain training facilities. The majority of the training practices are (still) single handed. The majority of the participating trainees are female and older than 30 years. The mean time reported by the trainees for study of the literature is about four hours a week, corresponding to half a day a week reserved for self-directed learning. The score for the trainer's appreciation of the trainee as pupil and future general practitioner ( 7 items) is 26.3 (range 7-35), which may be interpreted as "amply satisfactory". 
Table 2. Independent variables: Scale, Mean (M), and Standard Deviation (sd) of other than nominal variables, frequency counts for nominal variables, zero order Peasson correlations with the prestest and post-test score and the first onder partial correlations.

Scale Descriptive statistics Zero onder correlations First onder

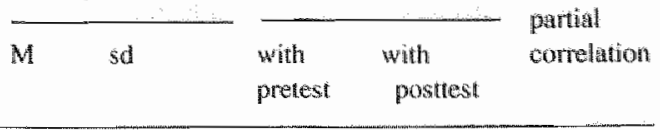

\section{Marbidity}

number of trainee's patient encounters/day'

R 20

20.6

5.4

$-.01$

$-.00$

$-\infty 0$

Trainer as generall practitioner

pre-test score trainer $(-100 \%-+100 \%)$

years of experience as $\mathrm{GP}$

raceived (one year) postgraduate training

$\begin{array}{ll}\mathrm{R} & 45.2 \\ \mathrm{R} & 15.4 \\ \mathrm{~N} & \text { yes:31 } \\ & \text { no: } 37\end{array}$

11.7

$-.04$

.03

.01

$5.1 \quad .23 \quad .10 \quad .07$

study of the literature (hours/week)

participation in CME (half days/year)

participation in medical audit

$\mathrm{R}$
$\mathrm{R}$
$\mathrm{N}$

traince"s appreciation for the trainer as GP

(sumscore, max. 25)

\section{Trainer as supervisor}

time spent on education

(registration, min/day)

number of trainees trained

R $\quad 2.5$

$-.02$

$-.14$

$-.14$

R 5.0

1.4

$37 *$

.07

$-38 *$

N yes: 24

3.7

$-.02$

$-.26$

$-30 *$

no: 34

years of experience in education

19.0

2.8

$-.07$

$-.36 *$

$-.28 *$

trainee's appreciation for the trainer as supervisor

(sumscore, max. 20)

$\begin{array}{ll}R & \\ R & 5 \\ R & 7 \\ \text { isor } \\ 0\end{array}$

\section{Practice}

equipment (sumscore, max. 47)

number of trainer's patient

encounters/week.

organization (solo: I vs group: 0)

$\begin{array}{ll}\mathrm{R} & 11.9 \\ \mathrm{R} & 187 \\ \mathbb{N} & 1.35 \\ & 0.23\end{array}$

urbanization []

o

70.3
5.4
7.0

31.6

$-.07 \quad-.18$

$-.17$

4.4

.16

$.28^{*}$

.16

4.9

.14

.07

$-.03$

14.9

3.4

$-.27^{*}$

$-.20$

$-.10$

\section{Trainee}

sed

N

$m: 24$

3.8

$-.05$

$-.27 *$

$-.19$

\section{age}

pre-test score trainee $(-100 \%+100 \%)$

wait between graduation and postgraduate

training (months)
number of jobs in the medical sector, preceding postgraduatetraining (each $>$ three months) study of the literature (hours/week)

trainer's appreciation (sumscore, max. 35)

N $\quad \begin{array}{ll}\mathrm{m}: 24 \\ \mathrm{R} 3\end{array}$

67

$.16 \quad-.01$

$-.05$

$-.12$

$-.10$

.19

$.33^{*}$

$.31 *$

R $\quad 30.9$

26

$$
-.06 \quad-.22
$$

$\mathrm{R}$

$.03 \quad-.20 \quad-.22$

$\begin{array}{lllll}R & 40.5 & 20.8 & -.02 & .11\end{array}$

$\begin{array}{rrrrrr}R & 2.2 & 1.0 & .03 & .16 & .07 \\ R & 4.2 & 2.9 & -.00 & -.24 & .01 \\ 0 & 26.3 & 4.4 & .19 & -.08 & -.08\end{array}$

* = significant $(p<0.05)$; scale: $N=$ nominal, $O=$ ordinal (Likert), $R=$ ratio; $[I=$ the number of inhabitants of the area of the training practice (four categories) from $<5.00010>100.000$. 
Table 3. Satisfaction of the tramee with the main components of training, expresssed as a mark between 1 and 10: mean ( $M$ ), standard deviation (sd); zero order correlation with pre- and post-test score and first order partial correlation.

\begin{tabular}{|c|c|c|c|c|c|}
\hline & \multirow[t]{2}{*}{ M } & \multirow[t]{2}{*}{ sd } & \multicolumn{2}{|c|}{ zero order correlation } & \multirow{2}{*}{$\begin{array}{l}\text { first order } \\
\text { partial } \\
\text { correlation }\end{array}$} \\
\hline & & & $\begin{array}{l}\text { with } \\
\text { pre-test }\end{array}$ & $\begin{array}{l}\text { with } \\
\text { postl-test }\end{array}$ & \\
\hline trainer & 7.4 & 1.5 & $-.29 *$ & $-.26 *$ & -.04 \\
\hline practice & 7.7 & 1.1 & -.11 & $-.28 *$ & -.26 \\
\hline theoretical curriculum & 6.9 & 0.9 & .11 & $.28^{* *}$ & .12 \\
\hline faculty & 7.2 & 1.0 & -.01 & .10 & .08 \\
\hline
\end{tabular}

*: significant $(p<0.05)$

Table 4. Step-wise regression analysis with the post-test score as dependent variable: the expained variance ( $R$-square), parameter estimate - non standardized (b) and standardized (B) - of the five items that explain the variance in post-test score.

\begin{tabular}{llcr}
\hline & R-square & \multicolumn{2}{c}{ parameter estimate } \\
\cline { 3 - 4 } & & \multicolumn{1}{c}{$\mathrm{b}$} & $\mathrm{B}$ \\
\hline pre-test score & & .549 & .499 \\
trainer's study of literature & .25 & -2.281 & -.294 \\
trainee 's appreciation for the trainer as GP & .46 & -.958 & -.274 \\
training institute F & .47 & -5.998 & -.248 \\
urbanization grade & .52 & 4.307 & .226 \\
\hline
\end{tabular}

The correlations of the training variables with the pre-test and post-test are reported to interpret the partial correlations appropriately. The partial correlation, representing the relation of each variable with the growth in knowledge during the 'intervention-period" is significant for four variables $(p<0.05)$ of which three refer to the trainer as general practitioner. All these associations are negative: the more time spent by the trainer on the study of literature ( -.38$)$ or on CME (-.30), the less growth in the trainee's knowledge. The more the trainees appreciate their trainer as general practitioner $(-.28)$, the less their growth in knowledge. The fourth significant (positive) association is reported for the urbanization of the practice area: the more urban the practice, the more growth in knowledge (.31). 
Table 3 shows the mean rating (scale 1 - 10) of the trainees for trainer, practice, theoretical curriculum and faculty, representing overall satisfaction with each of these.

The averages do not differ widely, clustering around 7 with a standard deviation of no more than 1.5. Alhough three of these variables are significantly associated with the post-test scone, the partial comelations are not significant, meaning that satisfaction with the training is not related to growth in knowledge.

Table 4 presents the results of the stepwise regression analysis. Only the variables with a significant contribution to the prediction are reported.

The pre-test score explains $25 \%$ of the variance in post-test score, all variables in combination about $50 \%$. Three of the four items significantly associated with the corrected post-test score (partial correlation), emerge again: the trainers of the less well performing trainees spend more time on study of the literature and are appreciated more; nore urban practices are associated with better performing trainees. Whereas Table 1 shows two institutes which demonstrate relatively little or no growth in knowledge, Table 3 shows that only one institute is negatively associated with growth in knowledge after correction for interactional effects.

\section{Discussion}

There is considerable growth in the trainees" knowledge during the first eight months of training in general practice. This study aimed at establishing the relation between this growth in knowledge and training variables.

From the results presented in Table 1 it might be concluded that the training institute does have an impact on growth in knowledge. The two institutes that, compared to the other five "show least growth in knowledge have a less structured programme for their day-release courses and spend more time on attitude-development and personality training than on the transmission of knowledge. The fact that only one of these two institutes is negatively associated with growth in knowledge after correction for interactional affects suggests that the variable "raining institule" represents more than merely the theoretical curriculum. Differences between the two institutes in number of urban versus non urban affiliated training practices might explair the actual result. As to the other training and trainee variables: the number of the trainee' $s$ patient encounters per day", the trainer as GP and supervisor, the practice and the trainee's prior and present activities appear not to explain the wariation in growth in knowledge. 
Four separate items explain only a small part of the variance. The reverse relation of three of them with growth in knowledge is difficult to interpret. Trainees who show more growth in knowledge appreciate their trainers less. It is unlikely that trainers who act as relatively bad 'role models' induce better trainee performance. What is more plausible is that the better performing trainees are more critical towards their trainers. Puzzling is the finding that trainers who spend more time on studying the literature have less well performing trainees. It should be noted that questionnaires like those used here elicit socially desirable answers, but it leaves open that there is no plausible explanation for a reverse relation. The urbanization of the practice area appears to be associated with growth in knowledge. The explanation, however, is again unclear. The urban practices do not have the most knowledgeable trainers, nor the best equipment, nor do trainees in these practices see more patients. A recent study suggests that the type of patient problems is positively related to the level of knowledge of general practitioners. ${ }^{14}$ The variation in patient morbidity may be more pronounced in urban than in rural practices.

Whatever the explanations, the extent of explained variance of the separate variables is small. The conclusion might be that the differences encountered in the training situation of the 58 trainees are of minor importance as far as the acquisition of knowledge is concerned. An alternative explanation is that the test does not represent general practice knowledge and is therefore inadequate to measure the effect of educational interventions. Close resemblance of the test cases to real patient problems and the demonstrated growth in knowledge argues for refuting this alternative explanation. ${ }^{30}$ It might be, however, that the education provided by the trainer in practice focuses predominantly on the approach of complex problems in which 'knowledge of the patient' plays a central role, whereas the test represents the "state of the art' relating to diagnosis and treatment of specific diseases.

A salient outcome of this study is that the trainee's 'prior knowledge' shows by far the highest correlation with the level of knowledge at the end of the first training period, which is even more obvious after correction for interactional effects: prior knowledge explains half of the $50 \%$ of explained variance in post-test scores. This raises the question whether the level of knowledge at the start of training should be an admittance criterion. To answer this question, further exploration of the predictive value of the knowledge of individual trainees is needed.

In this study "knowledge' was chosen as outcome measure. The transmission of knowledge is one of the major goals of postgraduate training. Moreover, the relation between knowledge and medical expertise has been theoretically outlined and empirically confirmed. ${ }^{10}$ Knowledge appears to be one of the essential elements of medical expertise, while knowledge test 
scores at graduation predict future performance fairly well. ${ }^{31}$ Nevertheless, it is only one aspect of the outcome of postgraduate training: on skills, attitude, working style and motivation, the different training components might show quite another impact.

In sum, postgraduate training for general practice remains, to a large extent, a 'black box'. Factors expected to influence growth in knowledge appear to be of little or no importance. Some factors, however, should be further explored, e.g. the content of the day release courses and the variation in patient morbidity. Variation in confrontation with specific problems and themes might be reflected in the test scores, which would be in accordance with the theory on medical expertise. ${ }^{10}$

The relation between the level of knowledge at the start of training and the level of knowledge after eight months shows that the acquisition of knowledge seems to be more a 'trainee-affair' than was expected. In view of the fact that the training has recently been prolonged from two to three years and priorities for further development of the training have to be estab》ished anew, this outcome is of current interest. Research related to learning styles ${ }^{32}$ and the role of self-directed learning should be encouraged.

\section{References}

I Lawrence M, Pritchard P, editors. General Practitioner Education; UK and Nordic Perspectives. London: Springer Verlag, 1992.

2 Boerma WGW, De Jong FAJM, Mulder PH. Health care and general practice across Europe. Utrecht: NIVEL/NHG, 1993.

3 Pereina Gray DJ. Assessment at last [Editorial]. Br J Gen Pract 1993; 43: 402-3.

4. Van Geldorp $\mathrm{O}$, et al. Opleiden en teren it de huisartsprakitik. [Training and learning in general practice]. Utrecht: Bunge, 1985.

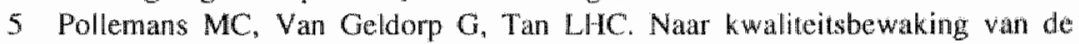
beroepsopleiding tot huisarts. [Towards quality assessment of postgraduate training for general practice]. Medisch Contact $1988 ; 46 ; 1429-30$.

6 Pereira Gray DJ. Training for general practice. London: Builer \& Tanner Lid, 1982.

7 Nelson MS, Clayton BL, Moreno R. How medical school faculty regard educalional research and make pedagogical decisions. Acad Med 1990; 65: 122-6.

8 Freeman J, Roberts J, Metcalf D, Hillier V. The influence of trainers on traineses in general practice [Occasional paper 21]. London: Royal College of General Practitioners, 1982.

9 Grol R, Mokkink H, Helsper-Lucas A, Tielens V, Bulle J. Effects of the vocational training of general practice consultation skills and medical performance. Med Educ: $1989 ; 23: 512-21$. 
10 Norman $G$. Allery L, Berkson $L$ et al. Research in the psychology of clinical reasoning: implications for assessment. In: Jolly $\mathrm{B}$, editor. New Directions in the Assessment of Clinical Competence. Proceedings Cambridge Conference IV. Cambridge University Press. 1989.

$\|$ Kramer A WM. Pollemans MC. Nationwide progress tests assessing knowledge in vocational training for general practice. In: Bender $W$, Hiemstra RJ, Scherpbier AJA, Zwierstra PR. editors. Teaching and Assessing Clinical Competence, Croningen: Boek Werk Publ, 1990.

12 Bordage $G$, Page $G$. An alternative approach to PMPs: the "key features" concept. In: Hart IR, Harden RM, editors. Further Developments in Assessing Clinical Compelence. Montreal: Heal Publications, 1987.

13 Var Leeuwen YD. Van Hessen PAW. Clinical competence and objective questions. Tactics to realize a true-false format assessing competence. In: Bender W. Hiemstral RJ, Scherpbier AJJA, Zwierstra PR, editors. Teaching and Assessing Clinical Competence. Groningen: BoekWerk Publ, 1990.

14 Pollemans MC. Kennistoetsing bij huisartsen. [Knowledge testing for general practitioners] [Dissertation].Maastricht: Datawyse/University Press Maastricht, 1994.

15 Van der Vleuten C, Verwijnen M. A system for student assessment. In: Van der Vleuten $C$, Wijnen W, editors. Problem based learning. Perspectives from the Matsuricht experience. Amsterdam: Thesis, 1990.

16 Grol $R$, Everwijn $S$, Dubois $V$. De meerjarige beroepsopleiding tot huisarts. IV: Opzet curriculum. [The three year curriculum for postgraduate training for general pratice. IV: curriculum design]. Medisch Contact 1987: 9: 279-82.

17 Dubois V, Everwijn S, Van Geldorp $G$, et al. The construction of a new curriculum of vocational trainung for general practice in the Netherlands. Utrecht: Royal Dutch Medical Association, 1987.

18 Irby DM. Clinical teacher effectiveness in medicine. J Med Educ 1978; 53:808-15.

19 Hay J, Acheson RM, Reiss BB, Evans CE. Teachers in general practice: a comparative study. Med Educ 1980; 14:277-84.

20 Ronalds C, Douglas A. Pereira Gray DJ, Selley P. Fourth National Trainee Conference. Report Recommendations and Questionnaire. [Occasional paper 18]. London: Royal College of General Practitioners, 1981.

21 McDonald PJ, Bass MI. Characteristics of highly rated family practice perceptors. J Med Educ 1983; 58: 882.93.

22 Farmer $\mathrm{E}$. Taylor S. Assessment of teaching by family medicine programme vocational trainees. Austr Fam Physician 1990; 4:549-57.

23 Lewis BS, Pace WD. Qualitative and quantitative methods for the assessment of clinical perceptors. Fam Med 1990; 5: 356-60.

24 Irby DM, Ransey PG, Gillmore GM, Schad D. Characteristics of effective clinical teachers of ambulatory care medicine. Acad Med 1991; 1: 54-5.

25 Stolk J. Tan LHC. Opleidingscontacten in de huisartspraktijk. [Educational encounters in general practice|, Bulletin Medisch Onderwijs $1992 ; 11: 62-6$.

26 Van der Vleuten CPM, Van Leeuwen YD, Mol S, Düsman H, Tan LHC, Grol R. Betrouwbalatheid van onderwijsregistraties in praktijkstages [Reliability of educational encounters in training practices!. In: Houtkoop E, Pols J, Pollemans M, Scherpbier A, Verwijnen M, editors. Gezond Onderwijs-III. Houten: Bohn, Stafleu, van Loghum, 1994.

27 Crocker L. Algina J. Introduction to Classical and Modern Test Theory. Orlandio: Holt, Rinehart and Winston, 1986. 
28 Cronbach LJ. How we should measure "change" - or should we? Psychol Bull 1970; 74: 68-80.

29 Blalock HM. Applied multivariate analysis and experimental designs. Beverly Hillis: SAGE Publications, 1984.

30 Swanson D. Case S. Trends in written assessment: a strangely biased perspective. In: Harden RM, Hart IR, Mulholland H, editors. Approaches to the Assessment of Clinical Competence. Dundee: Centre for Medical Education, 1992.

31 Norman G. Can an examination predict competence? The role of certification in maintenance of competence. Annals RCPSC 1991;2:121 4

32 Bligh JG. Independent learning among general practice trainees: an initial survey. Med Educ 1992; 26: 497-502. 
Chapter 7

\section{Selection for postgraduate training for general practice: the role of knowledge tests}

Y.D. van Leeuwen, S.S.L. Mol, M.C. Pollemans, C.P.M. van der Vleuten, R. Grol, M.J. Drop 


\section{Introduction}

Postgraduate uraining for general practice is a legal specialty training in most countries of the European Community. "The structure and content of the training vary from country to country but nearly all include training posts in general practice as well as in hospital.

Although its value for general practice is unquestioned, its effectiveness has only marginally been evaluated. It is largely unknown whether the outcome of the training is satisfactory or what the impact is of the separate training components. It is likewise unknown which characteristics or prior achievements of the trainee determine the outcome. The relation between "process' and 'outcome" has been investigated in a study recently performed in the Netherlands. ${ }^{2}$ Growth in knowledge during the first eight months of the training was chosen as outcome measure. The process variables included in the study were trainee's number of patient encounters, trainer, training practice and theoretical education. No evident relation was found between process and outcome. The trainees" level of knowledge at the start of training, however, appeared to explain a substantial part of the variance in level of knowledge after eight months $(25 \%)$.

A similar result has been found by Leigh et al. ${ }^{3}$ for the relation between in-training examinations for family residents and their certification examination and again for the relation between the level of knowledge of GPS at certification and their level of knowledge as demonstrated at recertification examinations six or more years later. ${ }^{4}$

These findings give rise to the question whether the trainees "level of knowledge at certification may be predicted by their knowledge test scores at entry or in the course of their training. A positive answer might warrant the use of knowledge tests in the context of selection. In most European countries selection at entry to postgraduate training for general practice is based on the assessment of a written application and a structured interview which focuses on motivation and prior professional experience. The agreement between interviewers is known to vary considerably while the predictive validity of this selection procedure for performance during the training is notoriously poor. ${ }^{5,6}$ Selection during training is mainly based on assessment of the trainee"s performance by the GP trainer ${ }^{7,8}$ Although the trainer seems the most appropriate judge of the trainee's performance, the trainer's simultaneous roles of colleague, supervisor and assessor hinders an objective assessment. Complementary, preferably objective assessment methods would be desirable. The question is whether knowledge testing would be a valuable addition to the selection methods applied. In other words, could the use of knowledge tests improve the accuracy of the decision to allow trainees either to enter or to continue their training? Among other things this depends on the predictive validity of these tests. 
This study investigates the predictive value of the two knowledge tests taken at entry and after eight months of training for the knowledge shortly before certification.

\section{Methods}

\section{Context of the study}

Since September 1994 postgraduate training in general practice in the Netherlands has consisted of three 'training-blocks' of 12 months each. The first and third are spent in general practice, the second in hospitals and other non-primary care settings. At the time of this study (1992) the entire training period was two years with three 'blocks' of eight months. The structure and content were largely the same. During the entire training period, one day a week is reserved for 'theoretical education' - so-called 'day release courses' - at the training institute, the department of general practice of one of the eight faculties of medicine in the Netherlands. At the end of the first block the training institute takes the formal decision whether or not to allow the trainee to continue training. This decision is based on the trainee's actual performance and the professional growth during the first block. The trainer"s judgement is of major importance.

\section{Subjects}

A longitudinal study was conducted in which all 85 trainees who started their training in January 1992 at one of the training institutes in the Netherlands participated.

\section{Instruments}

Knowledge was assessed by the National Knowledge Test for trainees in general practice, a paper and pencil test that is routinely administered to all GP trainees in the Netherlands at fixed intervals during their training. ${ }^{9}$

The test consists of about 80 patient cases as they are usually presented to the general practitioner, followed by one or more items. The items -160 in total - focus on the key features of the problem. ${ }^{10}$ Test content is selected on the basis of a multidimensional blueprint, established by consensus among general practitioners. "The test has a progress-testing format, 12 implying that, (a) the test is set at the level of the qualified general practitioner at the moment of certification, (b) successive tests are similar in format but wary in content and (c) all trainees take the same test regardless of their training level. The response format of the test is of the true-false-type with an additional 'I don't know' option. The final score is 
expressed as the percentage of correct minus incorrect answers. The validity of the test is reported in detail elsewhere. 13 Until now, the knowledge test has only had an educative function, enabling the trainees to detect their strengths, weaknesses and progress.

\section{Procedure}

Three knowledge tests were included in the study: the test taken shortly after the start of training (test 1), the test taken eight months later (test 2), the test taken at the end of the entire wo-year training period (test 3 ).

\section{Analyses}

To allow correction for item difficulty the tests were equated through a horizontal linear equation procedure with an anchor test consisting of $20 \%$ of the items of each test. 14 The equation was performed in pairs, each pair of two tests containing the same anchor test. The group mean scores per test of the trainees, expressed as the percentage correct minus incorrect of the maximum score were computed as well as the standard deviation and the 95\% confidence interval. The correlations (Pearson's r) between the three tests were computed, including a correction for attenuation (unreliability).

A multiple regression analysis was conducted, with test 3 as dependent variable and tests 1 and 2 as independent variables.

In addition, a logistic regression analysis was performed with the same independent variables. In this analysis the dependent variable is dichotomous, for example "passing" and 'failing". As cut-off score, two criteria were chosen. Firstly, the trainees" group mean score minus one slandarddeviation: the "minimum criterion". Scoring below this cut-off score implies that the trainee belongs to the $16 \%$ poorest scoring examinees. Secondly, the trainees' group mean score plus one standard-deviation: the 'excellence criterion'. Scoring above this cut-off score implies that the trainee belongs to the $16 \%$ best scoring examinees.

\section{Results}

All three tests were taken by 67 of the 85 trainees. At one institute test 3 could not be administered for logistical reasons, causing missing data of 12 trainees. The remaining missing data were due to absence of trainees because of illness, pregnancy, etcetera. The group mean score on test 1 and test 2 for the response and non-response group did not differ significantly $(T-t e s t 1=0.05 ;$ T-test $2=0.64 ;$ df 13,$66 ; p>0.05)$. 
Table 1 shows the mean test score, the standard deviation and $95 \%$ confidence interval for the three tests.

Table 1. Month of test administration, number of test items, test mean score $(\mathrm{M})$, standard deviation (SD) and $95 \%$ confidence interval $(95 \% \mathrm{CD}$ ) on the three (equated) tests compared $(\mathrm{N}=67$ tranees).

\begin{tabular}{lllll}
\hline Month & Items & M & SD & $95 \% \mathrm{Cl}$ \\
\hline 1 & 146 & 46.7 & 9.4 & $44.3-49.1$ \\
9 & 153 & 58.1 & 8.4 & $56.1-60.1^{*}$ \\
21 & 148 & 62.5 & 9.0 & $60.3-64.7^{*}$ \\
\hline
\end{tabular}

*: significant difference with preceding test $(s)(p<.05)$.

There is a significant increase in score in the course of the entire training period, which is most pronounced in the first eight months.

Table 2 shows the reliability of each of the three tests and the Pearson's r for the correlations between the three tests, also after correction for attenuation (correction for unreliability).

Table 2. Reliability (, bolded diagonal entries), correlations (Pearson $r$, in upper triangle) and correlations after correction for attenuation (italics, in lower triangle) between the three tests $(\mathrm{N}=67)$.

\begin{tabular}{llll}
\hline & Test 1 & Test 2 & Test 3 \\
\hline Test 1 & .68 & $.36^{*}$ & $.28^{*}$ \\
Test 2 & $.51^{*}$ & .71 & $.43^{*}$ \\
Test 3 & $39^{*}$ & $.60^{*}$ & .73 \\
\hline
\end{tabular}

*; significant $(\mathrm{p}<.05)$

The correlations are all significant. The highest correlation is found between tests 2 and 3 .

Table 3 shows the results of the stepwise multiple regression analysis.

The explained variance $\left(R^{2}\right)$ of test 3 by tests 1 and 2 is $20 \%$, largely due to the contribution of test $2(18 \%)$. The contribution of test 1 is not significant. 
Table 3. Stepwige multiple regression analysis with test 3 as dependent variable and testis $\llbracket$ and 2 as independent variables. estimate (b), standard error of estinate (SE), standardized estimate (B) and level of significance (sign.).

\begin{tabular}{lccccc}
$\begin{array}{l}\text { lndependent } \\
\text { variables }\end{array}$ & $\mathrm{R}^{2}$ & $\mathrm{~b}$ & $\mathrm{SE}$ & $\mathrm{B}$ & sign. \\
\hline Test 1 & .02 & .13 & .14 & .14 & .250 \\
Test 2 & .18 & .41 & .12 & .38 & .002 \\
\hline
\end{tabular}

Table 4 shows the results of the logistic regression analyses using the 'minimum criterion' and the 'excellence criterion".

Table 4. Logistic regression analysis for the best model, using the minimum and the excellence ariterion for test 3: chi-square, degrees of freedom (df), and level of significance $(p)$.

\begin{tabular}{lccc}
\hline & Chi-square & df & $p$ \\
\hline $\begin{array}{l}\text { Minimntm criterion } \\
\text { model without predictor }\end{array}$ & 63.0 & 66 & .58 \\
$\begin{array}{l}\text { (-2 log likellihood) } \\
\text { modell with test } 2 \text { as predictor }\end{array}$ & 55.7 & 65 & .79 \\
improvement & 7.3 & 1 & $.01 *$ \\
$\begin{array}{l}\text { Excellence criterion } \\
\text { model without predictor }\end{array}$ & & & \\
$\begin{array}{l}\text { (-2 log likellihood) } \\
\text { model with test } 2 \text { as predictor }\end{array}$ & 58.7 & 66 & .39 \\
improvement & 11.5 & 65 & .74 \\
\hline
\end{tabular}

*: significance $(\mathrm{p}<.05)$, indlicating that the model including the predictor decreases uncertainty significanily.

Table 4 shows that for both criteria the best model includes only test 2 , implying that only the contribution of test 2 to the prediction is significant. Adding test 1 does not enhance the prediction (improvement Chi-square $\min =.8 ;$ df $1 ; p=.38$; improvement chi-square excel $=.12 ; \mathrm{df} 1 ; \mathrm{p}=.73$ ).

An alternative way to show the predictive power of test 2 is to present the number of test 2 scores within the categories 'positive' and 'negative' predictors. For the minimum criterion test 2 scores above $42.6 \%$ (correctminus-incorrect answers) appear in $50 \%$ of cases to correspond with 'above minimum' on test 3 . For the excellence criterion the cut-off score 
Table 5. Observed (test 3) versus predicted (test 2) performance, using the minimurn and excellence criterion.

Observed performance (test 3 )

\begin{tabular}{|c|c|c|c|c|c|c|}
\hline \multirow{2}{*}{$\begin{array}{l}\text { Predicted } \\
\text { performance (test 2) }\end{array}$} & \multicolumn{3}{|c|}{ Minimum criterion } & \multicolumn{3}{|c|}{ Excellence criterion } \\
\hline & below & above & total & below & above & total \\
\hline Negative & 3 & 0 & 3 & 52 & 10 & 62 \\
\hline Positive & 9 & 55 & 64 & 1 & 4 & 5 \\
\hline Total & 12 & 55 & 67 & 53 & 14 & 67 \\
\hline
\end{tabular}

is $69.6 \%$ (correct minus incorrect answers). Test 2, positive -in combination with test 3 , above cut-off score and test 2 , negative - in combination with test 3 , below cut-off scores refer to correct predictions. Table 5 shows correct and incorrect predictions of test 2 for test 3.

The percentage of false negative predictions using the minimum criterion is $0 \%$, implying that all trainees classified by test 2 as 'below-minimum performers', actually score 'below minimum' on test 3. However, the corresponding percentage false positives, representing the percentage of trainees who are classified by test 2 as 'above minimum performers" and who nevertheless score 'below minimum' on test 3 is $14 \%(9 / 64)$.

The percentage of false negative and false positive predictions using the excellence criterion is $16 \%(10 / 62)$ and $20 \%(1 / 5)$ respectively.

\section{Discussion}

The results presented here warrant the following conclusions concerning the predictive validity of the 'entry test' and the 'eight months test'. The 'entry test' has little or no predictive value for the test at cerdification. The 'eight months test" does contribute significantly to the prediction of 'success' and 'failure' at certification. Both regression analyses, however, show that the prediction is not enhanced much by inclusion of this test compared to random prediction.

Using the minimum criterion, the predictive power of test 2 is, al first sight, not unfavourable if the first concern is to avoid false negative decisions: as few trainees as possible unjustly failed ( $0 \%$ false negatives). If, however, the major concern is to minimize false positive decisions, the outcome is less favourable ( $14 \%$ false positives). Reducing the percentage of trainees who are erroneously allowed to continue their training (for example to less than $5 \%$ ), implies that more trainees who are failed, should 
actually have continued their training (in case of less than $5 \%$ false positives: more than $75 \%$ false negatives!). The acceptability or unacceptability of the figures depends on the interests at stake. Boards responsible for the outcome of the training should decide what price to pay in terms of percentage of "incorrect" decisions for selection or early detection of either poor or excellent performers.

It should be noted that alternative criteria for success and failure may have yielded quite a different outcome. The scores of experienced GPS, for example, might be such a criterion. In a transversal study performed earlier, however, these GPs scored lower than trainees at certification 15 . Nearly all trainees would have met this criterion which yields redundant predictions.

The rather disappointing predictive power of the two first-year tests does not alter their value as instruments of feedback. Trainees have the opportunity to monitor their own performance and to detect their strengths and weaknesses. This may contribute to the efficiency of their self-directed learning. Moreover, monitoring the growth in knowledge of groups of trainees gives insight in the contribution of different training phases to growth in knowledge. The relatively large increase in knowledge during the first training phase, as demonstrated here, suggests that knowledge for general practice is decidedly different from knowledge acquired during undergraduate training. An intriguing question is whether the extension of the training from two to three years leads to further growth in knowledge. Reproducing this study for the three-year curriculum, including a larger sample of trainees, is highly recommended.

\section{References}

1 Boerma WGW, De Jong FAMM. Mulder PH. Health care and general practice across Europe. Utrecht: NIVEL/NHG 1993.

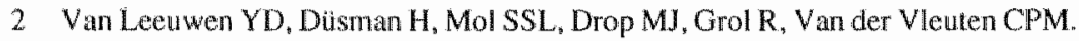
Factors influencing the growth in knowledge of traines in general practice. Under editorial review.

3 Leigh TM, Johnson TP. Pisacano NJ. Predictive walidity of the American board of family practice in-training examination. Acad Med 1990; 65: 454-7.

4 Leigh TM, Young PR, Haley JV. Performances of family practice diplomates on successive mandatory recertification examinations. Acad Med 1993; 68: 912-9.

5 Wright PM, Lichtenfels PA, Pursell ED. The structured interview: additional studies and a meta-analysis. Journall of Occupational Psychology 1989; 62:191-9.

6 Landsbergen EP. 'Nailing red jelly to the wall'. Selectie voor de medische vervolgopleiding. [Selection for medical postgraduate training]. In: Van der Vleuten CPM, Scherpbier AJJA, Pollemans MC, editors. Gezond onderwijs. Houten: Bohn, Staflet, Van Loghum: 1992.

7 Pereira Gray DJ. Training for general practice. London: Butler \& Tanner Ltd, 1982. 
8. Van Geldorp $\mathrm{G}$, redactie. Opleiden en leren in de huisartspraktijk. Training and learning in general practice]. Utrechi: Bunge. 1985.

9 Kramer AWM, Pollemans MC. Nationwide progress tests assessing knowledge in vocational training for general practice. In: Bender W. Hiemstra RI, Scherpbier AJJA, Zwierstra RP, editors. Teaching and Assessing Clinical Competence. Groningen: Boek Werk Publ, 1990.

10 Bordage $G$. Page $G$. An altemative approach to PMP's: the "key features" concept. In: Hart IR, Harden RM, editors. Further Developments in Assessing Clinical Competence. Montreal: Heal Publications, 1987.

11 Pollemans MC. Kennistoetsing bij huisartsen [Dissertation]. [Testing of knowledge of general practitioners.] Maastricht: Datawyse/Universitaire Pers Maastricht, 1.994.

12 Van der Vleuten $\mathbb{C}$, Verwijnen M. A systern for student assessment. In: Van der Vleuten $C$. Winen $W$, editors. Problem-based learning: Perspectives from the Maastricht experience. Amsterdam: Thesis, 1990.

13 Van Leeuwen YD, Pollemans MC, Mol SSL, Eekhof JAH, Grol R, Drop MJ. The Dutch knowledge test for General Practice: issues of validity. The European Joumal of General Practice 1995; 1: 113-7.

14 Crocker L, Algina J. Introduction to Classical and Modern Test Theory. Ortando: Holt, Rinehart and Winston, 1986.

15 Van Leeuwen YD, Mol SSL, Pollemans MC, Drop MJ, Grol R, Van der Vleuten CPM. Change in knowledge of general practitioners during their professional career. Family Practice 1995; 12: 313-7. 


\section{Chapter 8}

\section{General discussion}

\section{Introduction}

Although postgraduate training for general practice has a history of more than two decades, it is still unclear to what extent and in which way the training contributes to the development of competence of future general practitioners. This study aimed at revealing part of the inside of the "black box" of postgraduate training for general practice. Its focus was on knowledge: a knowledge test for general practice was validated and the impact of different training components on the trainee's growth in knowledge was investigated. Moreover, the predictive value of knowledge tests was explored in the context of their usefulness for selection purposes. The results can be summarized as follows: the knowledge test appeared to have acceptable validity and reliability to justify its use as measurement instrument in the present study. In order to use the test for assessment of individual trainees, especially for selection purposes, reliability and predictive validity remain to be improved. The trainees' level of knowledge increased substantially in the course of the two-year training, the largest increase occurring during the first eight months. An impact of the separate training components - patient, trainer as role model and supervisor, training-practice and theoretical curriculum - on the growth in knowledge of the trainee could not be demonstrated. No more evidence was found of an impact on the growth in knowledge of the time spent on educational encounters by trainer-trainee pairs.

In the following sections the results will be discussed in more detail.

\section{Test validation}

The validarion of the knowledge test served two purposes. The first was to explore the value of the Dutch Knowledge Test for General Practice as an instrument for the assessment of the level of knowledge of individual trainees. The second was to assess the suitability of the test to measure the outcome of postgraduate training in terms of knowledge acquisition. Test validation consisted of a study concerning content validity and construct validity as well as reliability. 
It was concluded that the content validity of the test was well supported. The introduction of a blueprint based on the task description of the Dutch GP and the procedure purswed of case and item construction, resulted in a test that meets Ebel's criterion of walidity: candidates should be assessed on the knowledge (and skills) they need in their professional life. ' Content validity, however, is 'provisional': each new test needs to be scrupulously composed, each new item carefully selected and formulated, reckoning with all the pitfalls that challenge validity. Adherence to strict procedures for test construction is therefore crucial.

The construct validity of the test, implying the concordance between the test results and the theory on knowledge acquisition, was endorsed by the outcome that test scores increase with training level. However, this operationalization of construct validity is not sufficiently compelling. Further confirmation of the hypothesis that the 'true' level of knowledge of (future) general practitioners is reflected in the test scores is desirable. The construct validity question might allso be reversed: assuming that the test has acceptable construct validity, what does this 'validity' exactly refer to, to what type of (general practice) knowledge? In the course of this discussion we will further explore this question.

The reliability of the test was investigated from different perspectives. The reliability of group scores appeared to be satisfactory, enabling use of the test for programme evaluation, whereas the reliability of individual scores turned out to be less satisfactory: for rankordering trainees and for assessing the extent of mastery of the domain, a higher reliability would be desirable. Lengthening of the test seems an obvious solution, which, however, poses feasibility problems as testing time would become unacceptable and test construction would overburden available resources. Combining the scores of two or more successive tests might be an alternative or additional option. This would imply that the combined score represents the level of knowledge at a certain point in time as well as the growth in knowledge during the subsequent period. This might, however, be an advantage, being in accordance with the view that progress is an indication of competence.

The reliability study yields sufficient data to warrant use of the test as a measurement instrument for the outcome of postgraduate training, providing that account is given to measures of imprecision.

\section{Growth in knowledge}

Growth in knowledge during training was demonstrated in a transversal as well as in a longitudinal study. What is intriguing is the 'plateau" from the eighth to the sixteenth month of training as found in the transversal study, which is confirmed by data derived from regular test administration 
since 1987. During that period the trainee spends nost of the time in hospital and other secondary care institutions. The present finding ma fuel the often expressed doubts relating to the effectiveness of these training posts in the context of postgraduate training for general practice. ${ }^{2}$ However, the specific objectives of these training posts require assessment of knowledge on less common conditions and assessment of skills, in order to draw definite conclusions.

The decrease in knowledge after certification as demonstrated in the transversal study elicits additional questions. Is this decay in knowledge related to career stage, due to lack of opportunity for practising GPS to keep their knowledge up to date, or is there, with growing experience, less need for the type of knowledge that is measured with the test. ${ }^{3,4,5}$ Hobus ${ }^{6}$ produced evidence that the diagnostic accuracy of GPS increases with level of experience which seems in contrast with the results of the present study. An alternative explanation is that trainees prepare themselves better for the test than GPs, who have no great stake in performing well on the test. This does not explain, however, the gradual decrease in level of knowledge with years of experience.

The different curves for changes in knowledge on the different subsections of the test suggest that the level of knowledge is related to the extent of exposure to patient problems and other 'sources of information' such as courses and seminars. For example, GPS are confronted with chronic illness more than their trainees whereas trainees have more opportunity to study and discuss Practice Guidelines. It seems worthwhille to further explore the relation between growth in knowledge and the actual content of education.

\section{The impact of training components}

The impact of different components of the training on the growth in knowledge of the trainee was explored in two studies. The first study related the time spent on education by trainer-trainee pairs to the trainee's growth in knowledge during the first training period, which is spent entirely in general practice. Contrary to our expectations no relation was found. In general, such a finding might be attributed to low variability, but here the opposite was the case: trainer-trainee pairs varied considerably in time spent on educational encounters, predominantly on those encounters focusing on the professional development of the trainee. The second study related the main components of postgraduate training, number of patient encounters, trainer as "role model" and supervisor, training practice and theoretical curriculum to the growth in knowledge of the trainee over the same period as in the first study. No convincing evidence for an impact of either training component on growth in knowledge was found. Four items 
appeared to explain a minor part of the variance in growth in knowledge. Two of them referred to the trainer as general practitioner: the trainers spending relatively less time on study of the literature and appreciated less as "role model" had trainees who showed relatively much growth in knowledge. In addition, least growth in knowledge was demonstrated for the two training institutes with the least structured programme for their theoretical education and the least emphas is on transmission of knowledge. For one of these institutes a negative relation with growth in knowledge remained after correction for interactional effects. Although the small number of trainees per training institute impairs generalization, this finding might indicate that the organization and content of the theoretical curriculurn have some impact on growth in knowledge.

The onlly positive relation with growth in knowledge was found for the urbanization of the practice area: trainees in urban practices performed relatively best. The relation being weak, further evidence should be awaited to infer a causal relationship.

In both studies discussed here, the variation in scores at the start of Iraining appeared to explain the variation in scores at the end of the first training block best. The results of these two studies are puzzling. Growth in knowledge during training being established, a plausible explanation for this growth is lacking. This may be due to the choice of independent variables. As suggested earlier, growth in knowledge may predominantly be determined by the actual content of patient encounters, educational encounters and theoretical education, which was not explored in this study. Moreover, trainee variables like learning style and motivation may play a significant role in the acquisition of knowledge. However, the absence of an impact of the training components included in this study on growth in knowledge, demands an explanation. Especially the one-to-one training situation seems too good an opportunity for learning to be dismissed as of minor importance.

\section{Back to validity}

Confusing or conflicting results oblige to a renewed appraisal of the measurement instruments. In this case the question is whether the knowledge test is sensitive enough or appropriate at all for the assessment of knowledge acquired during patient encounters and trainer-trainee encounters. Or, conversely, is this knowledge adequately reflected in the test?

The following considerations may be relevant in this respect.

The cases and items included in the test are actually derived from daily practice and reflect real doctor-patient encounters. However, certain types of cases are seldom included. Firstly, cases that can only be adequately solved if the doctor knows the patient well. For example, a doctor not 
familiar with the patient would miss a change in the patient's presentation compared to previous encounters, which might provide a clue to the solution of the problem. ${ }^{7.6}$ Or, the psychological constitution of the patient might justify or even dictate deviation from the standard approach.

Another type of cases that seldom appears in the test is those which need an extended narrative to describe, for example cases related to terminal care, sexual abuse, psychological decompensation, co-morbidity or complex pharmacological interactions. Exactly for these types of cases the trainee frequently consults the trainer, making particular use of the trainer's knowledge of the patient and his social context as well as of the trainer"s practical advice related to the sequence and spacing of actions in time.

One may conclude that the test content reflects a part of daily practice adequately but does not include all types of patient-problems presented to the general practitioner. In other words, what is assessed is 'necessary' but not 'sufficient'. 8

A second consideration concerning the test content may add to this argument. The test items are all provided with literature references. The reason is threefold. Firstly, it enables trainees to consult the literature for further study; secondly, it restricts the test content to knowledge that is publicly available; and lastly, it gives account of the correctness of the item: conflicting or missing evidence in the literature leads to elimination of the item. This procedure results in restricting the test content to 'evidence-based knowledge'. The term 'evidence-based knowledge" used here differs slightly in meaning from the term 'evidence-based medicine' as defined by the Evidence-Based Working Group. 9,10 The latter refers to knowledge that is based on evidence derived from sound clinical research, mostly randomized control trials. At the risk of introducing confusion, we apply the term 'evidence-based knowledge' here to the 'state of the art', which may partly be based on research, partly on common experience and generally accepted insights as presented in textbooks. Conversely, we use the term 'experience-based knowledge' for knowledge of individual GPs that is based on their personal practice experience. Much of the thinking and acting of general practitioners is experience-based. "l During trainertrainee encounters, predominantly this experience-based knowledge is transmitted. "The trainer usually discusses his approach with the trainee without providing an extensive argumentation or without discussing alternatives.

There is no reason to disapprove of such an attitude; scientific arguments are scarcely available and expertise is built to a large extent on personal experience as is outlined in the theory on the development of medical expertise. ${ }^{12}$ 
From the analysis presented here it may indeed be concluded that a discrepancy exists between the knowledge represented in the test and the knowledge transmitted during patient encounters in practice.

In summary, the test content is restricted to 'evidence-based knowledge" and to types of encounters that are rather straightforward, whereas in patient encounters and trainer-trainee encounters the trainee is frequently confronted with (complex) cases for which no evidence-based solution is available or provided. This discrepancy may explain the results of the present studies. It makes the decay in knowledge with increasing experience as a GP easier to interpret. During their professional career doctors steadily increase their experience-based knowledge and may feel less need to acquire additional evidence-based knowledge. Moreover, they have less access to it than trainees have. Likewise, the absence of an impact of the trainer on the trainee's growth in knowledge as assessed by the test is better explained. Moreover, the suggested impact of the theoretical curriculum, where predominantly evidence-based knowledge is transmitted, fits into this theory. Even the finding that trainees who score best on 'evidence-based knowledge' appreciate their 'experience-based thinking' trainers least seems less illogical. The final inference refers to the construct-validity of the test. The test may be regarded as an operationalization of the construct 'evidence-based general practice knowledge".

\section{Renewed appraisal of 'knowledge and medical expertise'}

The theory on the development of medical expertise, as outlined in the introduction of this dissertation, assumes that medical expertise originates from elaborated knowledge networks in the mind of the doctor into which knowledge derived from clinical practice is integrated on a continuous basis. This might imply that a sound theoretical basis together with long standing practice automatically leads to expertise. The findings of Hobus ${ }^{6}$ indeed seem to suggest that this is the case, that expertise grows with increasing experience-based knowledge.

The term 'expertise', however, contains a semantic pitfall. An experienced doctor may be an expert compared with an undergraduate medical student, but this by no means implies that s/he is an authority among fellow professionals. Those who are regarded as experts in the latter sense of the word, excel in critical appraisal of the literature as well as of clinical observation. Scrutiny of the literature may induce them to doubt their clinical observations or alter their clinical approach, whereas close observations in clinical practice may induce them to question established 
theories. This assumes continuous weighing of evidence-based and experience-based knowledge against each other.

Postgraduate training in whatever specialty aims at developing both sorts of expertise. Trainees should build on their experience-based knowledge by daily practice and by reflecting upon their experiences. In addition, they should maintain a scientific attitude, not necessarily to become 'authorities' but to keep up to date, which is conditional for the development of their specialty and thereby for the maintenance of quality of care.

\section{Implications for education and assessment}

Recently " the curriculum of postgraduate training for general practice in the Netherlands has been extended from two to three years, which enlarges the opportunities for teaching and learning. Priorities are defined and will be adjusted during the coming years. The results from the studies presented here may be translated into the following recommendations for education and assessment. As stated in the introduction to this dissertation, evidencebased medicine will play a role of increasing importance in the practice of medicine. This development underlines the importance of a well-strucm tured theoretical curriculum. Training in critical appraisal of the literature and participation in research projects form an invaluable part of it.

However, the importance of acquining experience-based knowledge should by no means be denied. Only a minor part of general practice is 'evidence-based' and a large part probably never will be." 13 The trainer is the transmitter 'par excellence' of experience-based knowledge. The complementary roles of trainer and training institute should be utilized in order to constitute a well-balanced training. ${ }^{14}$ Complementarity should, however, not imply that interaction between theory and practice is absent. Especially the training situation provides ample opportunity to compare the two and draw deliberate conclusions. Training institutes should $\mathrm{ex}^{\mathrm{x}}$ plicitly encourage this complementarity in order to produce general practitioners who maintain an attitude of life-long learning.

The knowledge test used in this study seems a valuable instrument for continual use during postgraduate training, assessing the trainees" evidencebased general practice knowledge. The progress testing format provides an excellent opportunity to record growth in knowledge. Il enables training institutes to evaluate the impact of courses and seminars which focus on evidence-based knowledge. Moreover, it provides insight into existing deficits in knowledge of individual trainees al regular intervals and may encourage self-directed learning. The low predictive value of knowledge test scores for achievement on a similar test at the moment of certification, 
impairs detection of trainees with a poor prognosis in this respect. However, the achievement at certification of most trainees is higher than that of GPS 5-10 years after certification, which lessens the need for such a prognosis. 15

Assessment of the effectiveness of the trainer's educational input and perhaps also of the effectiveness of the training posts outside the practice demand alternative assessment instruments. Observation of real or simulated patient encounters ${ }^{16}$ and perhaps even structured orals ${ }^{17}$ may be more appropriate than written tests.

It is surprising, that no postgraduate training in Europe includes a certifying examination ${ }^{18}$ especially now that recertification receives increasing attention. ${ }^{19,20}$ The lack of validated assessment instruments might have hindered its introduction, although in undergraduate medical education this has never been regarded as a serious obstacle. The absence of a definition of 'the good general practitioner' is often proclaimed as the deciding reason. ${ }^{21}$ Now that the public increasingly demands proof of competence of certified doctors, it is doubtful whether one can retain much longer from assessment at certification. ${ }^{22}$ Defining a negative criterion, achievement indicative for lack of competence, may facilitate pass-fail decisions. A certifying exam should be composed of a variety of elements that cover a range of abilities, ${ }^{21}$ including skills in management and patient education, as well as critical thinking. A knowledge test, assessing evidence-based knowledge, should decidedly be part of it.

\section{References}

1 Ebel R. The practical validation of tests of ability. Educ Meas, issues pract 1983: $2 ; 7-10$.

2 Murphy A. The hospital component of general practice vocational training" persistent preventable problems. Education for General Practice $1995 ; 6: 19-29$.

3 Norcini JJ, Lipner RS, Benson JA, Webster GD. An analysis of the knowledge base of practicing internists as measured by the 1980 recertification examination. Ann Intern Med 1985; 102: 385-9.

4 Dry SC, Norcini JJ, Webster GD, Viner ED, Chirioco AM. The effect of changes in medical knowledge on examination performance at the time of recertification. Proceedings of the 27th Annual Conference of Research in Medical Education. Chicago, III: Association of American Medical Colleges, 1988.

5 Leigh TM, Young PR, Haley JV. Performances of family practice diplomats on successive mandatory recertification examinations. Acad Med 1993; 68:912-9.

6 Hobus P. Expertise van huisartsen. [Expertise of general practitioners.] [Dissertation]. Masstricht" Rijksuniversiteit Limburg, 1994.

7 Baggen JL, Van Leeuwen YD. Kans en differentiele diagnostiek. [Probability and differential diagnosis]. The Practitioner 1984; $1379-88$. 
8 Nagell E. The Structure of Science. Problems in the logic of scientific explanation. London: Routledge \& Kegan Paul 1982.

9 Evidence-Based Medicine Working group. Evidence-based medicine: a new approach to teaching the practice of health care. IAMA 1992; 268:2420-5.

10 Burtinx F. The Cochrane Collaboration, information overload and European General Practice. Eur J Gen Pract 1995; 6: 19-29.

11 Ridsdale L. Evidence-based general pracice. A critical reader. London: Sanders Company Lud, 1995.

12 Norman G, Allery L, Berkson L. Research in the psychology of clinical reasoning: implications for assessment. In: Jolly B, editor "New directions in the Assessment of Clinical Competence. Proceedings Cambridge Conference IV. Cambridge: Cambridge University Press, 1989.

13 Lohr KN. Gudelines for clinical practice: applications for pringary care. Int J Qual Health Care 1994; 6: 17-25.

14 De Vries B. Het leven en de leer. Een studie naar de verbinding van leren en werken in de stage [Dissertation]. Nijmegen: Instituut woor Toegepaste Sociale Wetenschappen, 1988 .

15 Borlase $\mathrm{BC}$, Bratle EJ, Moore EE. Does the in-service training examination correlate with clinical performance in surgery?

16 Rethans JJ, Sturmans F, Drop R, Van der Vleuten C. Assessment of the performance of general practitioners by the use of standardized (simulated) patients. Br J Gen Pract; 41: $97-9$.

17 Klaassen T, Van der Vleuten CPM, Rotteveel RJ. De betrouwbaarhied van het mondelinge examen nader bekeken. [Renewed appraisal of the reliability of orals]. Bulletin Medisch Onderwijs 1994; 13: 155-61.

18 Boerma WGW, De Jong FAJM, Mulder PH. Health care and general practice across Europe. Utrecht: Netherlands Institute of Primary Health Care, 1993.

19 Anonymus. De positie van de huisarts in de toekomst. Discussienota. IThe future position of the general practitioner. Discussion paper] Utrecht: Landelijke Huisartsen Vereniging, 1987.

20 Newble D, Jally B, Wakeford R, editors. The Certification and Recertification of Doctors: Issues in the Assessment of Competence. Cambridge: Cambridge University Press, 1994.

21 Lawrence M. Pritchard P, editors. General Practitioner Education. UK and Nordic Perspectives. London: Springer Verlag, 1992.

22 Pereira Gray DJ. Assessment at last [Editorial]. Br J Gen Pract 1993; 43: 402-3. 



\section{Summary}

In chapter 1 the objectives and context of the study are described. The study aimed at investigating the relation between the process and outcome of postgraduate training for general practice. The process refers to the specific elements of the training, the outcome is defined in terms of knowledge acquisition.

At the time of this study postgraduate training for general practice in the Netherlands consisted of a two-year training period with specified learning objectives and an extensive curriculum. The core element of the training is a training post in general practice, supervised by a GP trainer. One third of the time is spent in general hospitals, geriatric hospitals and ambulatory care units for psychosocial problems. One day a week, the trainees attend group meetings of 12 to 13 trainees, the so-called 'day release courses", organized by the training institute.

At face value the training appears to prepare the future general practitioner well for his/her task. However, this favourable impression is not grounded in sound empirical evidence. Research in this freld is poor and leaves questions concerning the level of competence at certification and the impact of separate training components unanswered. In this dissertation the impact of postgraduate training on the growth in the trainee's knowledge is explored. The choice for knowledge as outcome measure is argued on the basis of recent developments in general practice, implying that the decision-making of doctors is increasingly based on the outcome of clinical research in primary care. Furthermore, research in the field of cognitive psychology shows, that knowledge, more than was previously assumed, is crucial to the quality of medical decision-making.

The methods for assessment of this type of knowledge are discussed. A test, already applied in the training since 1987, seems to meet the demands of sound knowledge testing in a postgraduate setting. This test administered to all GP trainees in the Netherlands - consists of written patient problems, similar to those presented to the general practitioner during surgery. The answer-format is of the true/false/? type. The test has a progress testing format. Each of the six similar tests administered at fixed intervals during the training is taken by all trainees, regardless of their training level. The items represent the required level of knowledge at 
certification. Progress during training and the approach of trainees towards the required level of expertise can thus be monitored.

Validation of this test is part of this disseration.

The research questions concerning postgraduate training are:

- What is the growth in knowledge of trainees during postgraduate training for general practice and what is the level of knowledge reached at the end of training?

- What is the impact of the different components of postgraduate training, e.g. patient morbidity, trainer, practice and theoretical education, on the trainee's growth in knowledge?

In chapter 2 the validity of the knowledge test for general practice is investigated with the focus on content validity and construct validity. Content validity refers to the representation of current general practice in the test. A first prerequisite is that the test covers the domain of general practice. A multidimensional blueprint was defined for this domain. The main dimension of the blueprint covers complaints and diseases, whereas additional dimensions provide an adequate age distribution of patient cases in the test, refer to different aspects of the consultation (diagnosis versus treatment), and provide the test with enough patient cases on, for example, emergency and chronic illness. The blueprint was endorsed by the profession, represented by several bodies from the Dutch College of General Practice and the training institutes. In addition, the procedure and result of case and item construction was assessed and approved.

Construct validity here refers to the concordance between the theory on growth in knowledge and the test results. It was assumed that the test scores would increase with the stage of medical training. This was investigated by comparing mean scores of medical students, GP trainees of different levels of postgraduate training and qualufied general practitioners.

The mean group score increases with training llevel. The mean score of trainees at the end of training surpasses the mean score of qualified general practitioners. It is concluded that the test assesses knowledge that is closely related to the general practitioner's daily work. Furthermore, the test is considered appropriate to monitor the growth in knowledge of trainees during postgraduate training.

In chapter 3 the reliability of the test is studied with the use of generalizability theory. This theory allows estimation of reliability from different perspectives representing different educational goals: to rankorder candidates (norm-oriented perspective), to estimate their level of knowledge expressed as percentage of the maximum level (domainoriented perspective) or to take justifiable pass-fail decisions (decision- 
oriented perspective). With 160 test items the rellability estimate is .71 from a norm-oriented perspective and .67 from a domain-oriented perspective. Estimates from a decision-oriented perspective vary between .67 and .95 depending on the position of the cut-off score, closer or farther from the group mean score. These results imply that caution should be exercised in the interpretation of the rank-onder of candidates or of their absolute score level. Lengthening of the test to 320 items would increase reliability to .80 but would at the same time double testing time to four hours. Combining the results of two or more successive tests may be a suitable alternative. Reliable pass-fail decisions assume a cut-off score at sufficient distance from the group mean score. This cut-off score should, however, be realistic: a too high or too low pass-fail caesura might no longer represent sufficient versus insufficient knowledge with reference to patient care in general practice.

Reliability estimates of group mean scores prove considerably higher, which allows the use of the test for purposes of programme evaluation.

In chapter 4 the results are presented of a transversal study on the level of knowledge of general practitioners in different career-stages. Their total body of knowledge as well as their knowledge about specific aspects of general practice care was investigated: diagnosis and treatment, serious and non-serious conditions, chronic and acute illness and knowledge concerning Practice Guidelines. Participants were 108 medical students, 445 postgraduate trainees in six different stages of their training and 351 GPs with five to more than twenty years of experience.

Test scores increase from the start of posigraduate training onwards towards 5-10 years after certification, the largest increase appearing during the first eight months of training. Stagnation occurs during the ninth until the sixteenth month of training, the period reserved for training posts in hospitals and other secondary care instilutions. From 5-10 years after certification onwards test scores gradually decrease. The curves for the different aspects of care vary only slightly.

It is concluded that postgraduate training for general practice contributes substantially to growth in knowledge resulting in a satisfactory level of knowledge at certification, being the levell of practising GPs who have been certified less than 10 years ago. The decrease in knowledge after certification found here thas also been demonstrated in two American studies on the knowledge of certified GPs and internists. Does clinical experience lessen the want and/or the need to maintain the level of factual knowledge? Or does Continuing Medical Education provide insufficient opportunity for keeping 'up to date'?

Chapter 5 describes a study on the time spent on educational encounters during the first eight months of postgraduate training. The relation of the 
trainer's workload, clinical and educational experience with the time invested in educational concounters was explored. Moreover, the impact of the time spent on educational encounters on the trainee"s growth in knowledge was investigated. During 12 days 58 trainees registered the time spent on nine different types of educational encounters, for example evaluation of patients or observation by the trainer of the trainee's patient encounters. The average time spent on educational encounters per day is about one hour, which meets the standard formulated by most training institutes. The variation between trainer-trainee pairs, however, is substantial, varying from 17.5 to 206.3 minutes per day. Most time is spent on evaluation of the trainee's patient encounters, which predominantly focus on the quality of care provided by the trainee. Least time is spent on those types of encounters that focus predominantly on the trainee's professional development. Trainers spending relatively more time on the latter are appreciated best by their trainees.

The time spent on educational encounters neither shows a relation with the trainer's workload and clinical and educational experience nor with the trainee"s growth in knowledge. These results are counter to our expectations. Is the quantity of education in practice indeed of minor importance? Or is the choice of growth in knowledge as outcome measure less for tunate? It may be that the educational input of the trainer affects predominantly the trainee"s management skills, working style and motivation, variables not explored in this study.

In the study presented in chapter 6 the relation between the process and outcome of the first eight months of postgraduate training for general practice was investigated. A significant increase in mean test score was demonstrated. None of the main training variables (number of patient encounters, trainer, practice, theoretical curriculum) appeared to have a significant impact on this growth. Two items referring to the trainer in his quality as GP showed a reverse relation with growth in knowledge for which no plausible explanation was found. A strong positive relation was found between the level of knowledge at the start of training and the level of knowledge eight months later. This might imply that characteristics of the trainee e.g. learning style and motiwation, determine the growth in knowledge during training to a larger extent than characteristics of the training situation. However, the content of the theoretical curriculum and the patient-mix presented to the trainee, variables not included in this study, might be of additional importance.

The aim of the study described in chapter 7 is to investigate whether knowledge tests may be used in the context of selection, either at entry or during the course of the training. Until now, selection at entry is based on the assessment of a written application and a structured interview. The 
agreement between interviewers is known to vary considerably while the predictive validity for performance during the maining is notoriously poor. Selection during postgraduate training for general practice is mainly based on assessment of the trainee's performance by the GP trainer. Although the trainer seems the most appropriate judge of the trainee's performance, the trainer's simultaneous roles of colleague, supervisor and assessor hinders an objective assessment. To investigate, whether knowledge testing at entry or after eight months of training, would be a valuable addition to the selection methods applied, the predictive value of the knowledge test was explored. The final test - taken shortly before the end of training - served as criterion for the predictive validity of the test taken at entry and the test taken eight months later as well as of these two combined. A stepwise multiple regression analysis with the final test as dependent variable, showed a neglectible predictive power of the tests, either or not combined. Additionally, it was explored, to what oxtent the two test could predict the final outcome if the final test results were dichotomized, in other words, if a final 'pass-fail' criterion was introduced. Two arbitrary cut-off scores were selected, the "minimum criterion" (below cut-off score' representing the $16 \%$ poorest scoring trainees) and the 'maximum criterion' ('above cut-off score' representing the $16 \%$ best scoring trainees). Logistical regression analysis showed, that the prediction of "failing" or 'passing' on the finall test, using either criterion, was low. The only exception was the prediction of 'below minimum' by the eight months test: scoring about two standard deviations below the group mean score on the eight months test corresponded $100 \%$ with below minimum scoring' on the final test. This applied to $5 \%$ of the trainees. Conversily, $14 \%$ of the trainees who scored below minumum in the end, were not 'detected' by the eight months test. Reducing the percentage of false positives (for example to $5 \%$ ) would increase the percentage of false negatives (to over $75 \%$ ). The outcomes using the maximum criterion were even less promising.

In chapter 8 the main conclusions are presented. The knowledge test is an appropriate measurement instrument to monitor the growth in knowledge of groups of trainees and to provide periodic feedback on the trainee's strengths and weaknesses. The use of the lest as measurement instrument in the present study on growth in knowledge is justified. Selection of trainees early in the training on the basis of knowledge test results is hampered by their low predictive validity for the level of knowledge at certification. The average growth in knowledge during training, however, is substantial, resulting in a satisfactory level of knowledge at certification. There is no evidence of an impact of the separate training components on the trainee's growth in knowledge. 
The fact that no relation between specific educational input and outcome in terms of growth in knowledge could be demonstrated, evokes the question whether the knowledge test is appropriate to assess the knowledge acquired during patient encounters and trainer-trainee encounters.

It is suggested that there may be two different types of general practice knowledge: 'evidence-based knowledge', the knowledge represented in the literature and "experience-based knowledge', generated in individual practice and increasing with clinical experience. The test content may represent predominantly 'evidence-based knowledge', whereas the knowledge transmitted during patient encounters and trainee-trainer encounters is largely 'experience-based'. This distinction makes the results of the present studies easier to interpret. The decay in evidence-based knowledge with increasing experience as GP is better understood: the GP increasingly relies on his/her experienced-based knowledge. Consequently, it is better understood that the trainer has no evident impact on the trainee's growth in (evidence-based) knowledge.

It may follow that the test is an operationalization of the construct 'evidence-based general practice knowledge'. With reference to the distinction between evidence-based knowledge and experience-based knowledge two sorts of 'expertise' should be defined. The first refers to the level of experience as professional, the second to authority in a certain field. The former increases more or less automatically with years of experience, the latter assumes adequate use of evidence-based and experience-based knowledge in combination.

Recommendations for education and assessment include the following suggestions. Given the fact that evidence-based knowledge and experience-based knowledge are of equal importance, a well balanced training programme implies complementary roles for theory and practice, for training institute and trainer. Moreover, training institutes should explicitly encourage trainees to integrate theory and practice, notably by developing the trainee's skills in audit and in critical appraisal of the literature.

The knowledge test used in this study is regarded a valuable instrument for continual use during postgraduate training. The progress testing format enables trainees to monitor their own progress and to organize their self-directed learning. There is hardly any need for selection of trainees on the basis of knowledge test results early in the training, given the satisfactory level of knowledge of most trainees at certification. Adequate methods should be applied to assess the effectiveness of the trainer"s educational input and the effectiveness of the training posts outside the practice. A claim is made for a certifying examination which includes a variety of methods to assess a range of abilities. Knowledge testing is proclaimed an indispensable part of it. 


\section{Samenvatting}

In hoofdstuk $\mathbb{1}$ worden doel en context van het onderzoek beschreven. Het onderzoek richtte zich op het verband tussen de inhoud van de huisartsopleiding en het 'product', hier gedefinieerd in termen van kennisverwerving door de huisarts in opleiding (haio).

In de periode dat dit onderzoek werd uitgevoerd, bestond de huisartsopleiding in Nederland uit een tweejarige opleidingsperiode met gespecificeerde leerdoelen en een uitgewerkt curriculum. De opleiding in de huisartspraktijk met supervisie van een huisarts-opleider, vormt de kem van de opleiding. Een derde van de opleiding wordt doorgebracht in algemene ziekenhuizen, verpleeghuizen en RIAGG's. Eén dag per week volgen de huisartsen-in-opleiding onderwijs in groepen van 12 tot 13 , het 'terugkomdag-onderwijs'. Dit wordt georganiseerd door het opleidingsinstituut.

Op het oog lijkt de opleiding de toekomstige huisarts goed voor te bereiden op zijn/haar taak. Deze gunstige indruk stoelt echter niet op deugdelijk empirisch bewijsmateriaal. Er bestaat weinig onderzoek op dit gebied, waardoor weinig inzicht bestaat in het competentieniveau van de haio's aan het eind van de opleiding, en de invloed hierop van de afzonderlijke onderdelen van de opleiding. In dit proefschrift wordt de invloed van de huisartsopleiding op de groei in kennis van de haio nader onderzocht. Er is gekozen voor kennis als uitkomstmaat op grond van recente ontwikkelingen binnen de huisartsgeneeskunde inhoudende dat het handelen van huisartsen in toenemende mate stoelt op resultaten uil eerstelijns klinisch onderzoek ('evidence-based medicine'). Verder leidt onderzoek op het gebied van de cognitieve psychologie tol de conclusie dat kennis - meer dan voorheen werd aangenomen - de kwaliteit van het klinisch denken bepaalt.

De methoden om deze kennis te toetsen worden bediscussieerd. Een reeds in de opleiding gebruikte toets lijkt aan de eisen te stellen aan een deugdelijk instrument voor kennistoetsing in een beroepsopleiding te voldoen. Deze toets - die sinds 1987 bij alle haio's in Nederland wordt afgenomen - bestaat uit schriftelijke patiënt-problemen, die vergelijkbaar zijn met de problemen die de huisarts in de praklijk tegenkomt. De toetsvragen zijn van het juist-onjuist-vraagteken-type. Het betreft een voortgangstoets. Elke van de zes soortgelijke toetsen die op vaste momen- 
len gedurende de opleiding worden afgenomen, wordt door alle haio"s gemaakt ongeachi de fase wan de huisartsopleiding waarin ze verkeren. De toetswragen representeren de kennis die aan het eind van de opleiding moet worden beheerst. Zo kan de voortgang gedurende de opleiding en de wijze watrop de haio's groeien naar het vereiste expertiseniveau, in kaart worden gebracht.

De validering wan deze toets is onderdeel van dit proefschrift.

De onderzoeksvragen met betrekking tot de huisartsopleiding zijn:

- Wat is de groei in kennis van haio's gedurende de huisartsopleiding en welk kennisniveau word aan het eind van de opleiding bereikt?

- Wat is de invloed van de verschillende onderdelen van de huisartsopleiding, zoals patiëntenaanbod, opleider, praktijk en theoretisch onderwijs, op de groei in kennis van de haio?

In hoofdstuk 2 wordt de validiteit van de huisartsgeneeskundige kennistoets onderzoch, waarbij de nadruk ligt op inhouds-en construct-validiteit. Inhoudsvaliditeit verwijst naar de mate waarin de toets de actuele huisartsgeneeskunde representeert. Een eerste vereiste is dat het domein van de huisartsgeneeskunde door de toets wordt gedekt. Om een adequate dekking van het domein te bereiken, werd een multi-dimensionale blauwdruk voor het huisartsgeneeskundig domein opgesteld, bestaande uit een 'hoofdindeling' en vier 'nevenindelingen'. De hoofdindeling wan de blauwdruk omvat klachten en aandoeningen. De nevenindelingen garanderen dat in de toets de patiëntencasus evenwichtig naar leeftijd zijn verdeeld, dat de verschillende aspecten van het consult (diagnostiek en beleid) voldoende aan bod komen, en dat de toets voldoende casus bevat over verschillende thema's, bijvoorbeeld spoedgevallen en chronische aandoeningen. De blauwdruk werd geaccordeerd door de beroepsgroep bij monde van afgevaardigden van het Nederlands Huisartsen Genootschap (NHG) en van de opleidingsinstituten. Ook de wijze van casus- en toetsvragen-constructie werd adequat bevonden.

Constructvaliditeit verwijst hier nat de overeenstemming tussen de op grond van de theorie verwachte groei in kennis en de in het onderzoek aangetoonde groei. Verondersteld werd dat de toetsscores hoger zouden zijn naarmate men verder met de opleiding was gevorderd. Dit is onderzocht door de gemiddelde scores te vergelijken van medische studenten, haio's in verschillende opleidingsfasen en ervaren huisartsen.

De gemiddelde groepsscore blijkt toe te nemen met het opleidingsniveau. Het kennisniveau van de haio's aan het eind van de opleiding blijkt ruimschoots dat van ervaren huisartsen te evenaren. Geconcludeerd word: dat de toets kenmis toetst die nauw verbonden is met het dagelijks werk van de huisarts. Verder wordt de toets beschouwd als een geschikte 
methode on de groei in kennis van haio"s gedurende hun opleiding in kaari te brengen.

In hoofdstuk 3 wordt de betrouwbartheid van de toets beschreven, waarbij gebruik wordt gemaakt van de generaliseerbaarheidstheorie. Deze theorie maakt betrouwbaarheids-schattingen mogelijk vanuil verschillende perspectieven die overeenkomen met verschillende onderwijsdoelen: rangordenen van kandidaten (normgeoriënteerd perspectief), bepalen van het kennisniveau uitgedrukt als percentage van het maximaal te behalen niveau (domeingeoriënteend perspectief), en het nemen van verantwoorde zak-slaagbeslissingen (beslissingsgeoriènteerd perspectief).

Bij 160 toetsvragen is de betrouwbarheid vanuit het normgeorienteerde perspectief .71, en .67 vanuit het domeingeoriënteerde perspectief. Betrouwbaarheids-schattingen vanuit het beslissingsgeorieinteerde perspectief variëren tussen .67 en .95 afhankelijk van de positie van het afkappunt, dichterbij, respectievelijk verder af van de gemiddelde groepsscore.

Deze resultaten impliceren dat voorzichtigheid moet worden betracht bij de interpretatie van de rangorde van kandidaten of van hun absolute scoreniveaw. Verlenging van de toets tot 320 toetsvragen zou de betrouwbaarheid tot 80 verhogen, maar zou tegelijkertijd een verdubbeling betekenen van de toetstijd, tot vier uur. Het combineren van de resultaten op twee of meer opeenvolgende toetsen lijkt een geschikt alternatief. Betrouwbare zak-slaagbeslissingen vooronderstellen een cesuur die voldoende veralligt van de gemiddelde groepsscore. Deze cesuur dient echter een realistische te zijn: de zak-slaaggrens zou de grens moeten markeren tussen voldoende en onvoldoende kennis met betrekking tot patiëntenzorg in de huisartspraktijk.

Betrouwbaarheidsschattingen van groepsscores blijken vanuit alle perspectieven aanzienlijk hoger, hetgeen de toets geschikt maakt voor het vaststellen wan de effectiviteit van onderwijsprogramma"s.

In hoofdstuk 4 worden de resultaten gepresenteerd van een transversale studie naar het kennisniveau van huisartsen in verschillende stadia van hun carrière. Zowel hun algehele kennis als hun kennis op deelgebieden is onderzocht. De deelgebieden betreffen verschillende aspecten van zorg. zoals diagnose en therapie, ernstige en mieternstige aandoeningen, chronische en acute aandoeningen, en kennis over Standaarden. Deelnemers waren 108 medische studenten, 445 haio's in zes verschillende opleidingsfasen, en 35 I huisartsen met vijf tot ruim twintig jaar ervaring.

De toetsscores stijgen vanaf het begin van de huisartsopleiding tot het niveau van 5-10 jaar na het eind van de opleiding. De grootste toename vindt plaats gedurende de eerste acht opleidingsmatanden. Gedurende de negende tot zestiende opleidingsmaand is er sprake van een zekere stag- 
natie. Dil is de periode die is gereserveerd voor opleliding in ziekenhuizen en andere weedelijns-instellingen. De toetsscores nemen $5-10$ jaar na het afstuderen als huisaris geleideligk af. De curves voor de verschillende aspecten wan zorg varieren enigszins.

Geconcludeerd wordt dat de huisartsopleiding substantieel bijdraagt aan de groei in kennis, hetgeen resulteent in een kennisniveau aan het eind varn de opleiding dat samenvalt met het niveau van praktiserende huisartsen die minder dan 10 jaar tevoren hun huisarts-opleiding afsloten. De afname in keninis nat afoop van de huisartsopleiding die in dit onderzoek is gevonden, is ook aangetoond in twee Amerikaanse studies naar de kennis van gediplomeerde huisartsen en internisten. Leidt klinische ervaring ertoe dat de noodzaak en/of de behoefte om het feitelijke kennisniveau op peil te houden, vermindert? Of biedt de nascholing onvoldoende gelegenheid om bij te blijven?

Hoofdstuk 5 beschrijft een studie naar de tijd die in de huisartspraktijk wordt besteed aan opleidingscontacten (tussen opleider en haio) gedurende de eerste acht opleidingsmaanden. Het verband is onderzocht tussen de werkbelasting van de opleider en diens klinische en onderwijskundige ervaring enerzijds, en de in onderwijs aan de haio geinvesteerde tijd anderzijds. Bovendien is nagegaan wat de invloed is van de tijd die aan opleidingscontacten wordt besteed op de groei in kennis van de haio. Gedurende 12 dagen registreerden 58 haio"s de tijd die werd besteed aan negen verschillende soorten opleidingscontacten, bijvoorbeeld nabespreking van patiènten en observatie van haio-consulten door de opleider.

De gemiddelde tijd die per dag aan opleidingscontacten wordt besteed is ongeveer een uur, hetgeen overeenkomt met de norm die daarvoor door de opleidingsinstituten is opgesteld. De variatie tussen haio-opleider-koppels is echter aanzienlijk, variërend van 17.5 tot 206.3 minuten per dag. De meeste lijd wordt besteed aan evaluatie van patiènt-contacten van de haio, warin doorgaans de kwaliteit van de zorg die door de halo is geboden centratl staat. De minste tijd wordt besteed aan die typen van contacten die vooral betrekking hebben op de professionele ontwikkeling wan de haio. Opleiders die hieraan, naar verhouding, veel tijd besteden worden het best gewaardeend door de haio's.

De tijd die aan opleidingscontacten wordt besteed, laat geen relatie zien met de werkbelasting van de opleider en diens klinische en onderwijskundige ervaring, noch met de groei in kennis van de haio. Vooral dit laatste is in tegenspraak met onze verwachtingen. Is de hoeveelheid onderwijs in de praktijk van weinig belang? Of is de keuze van groei in kennis als witkomst-maat minder gelukkig? Het is mogelijk dat de onderwijskundige input van de opleider voomamelijk de organisatorische vaardigheden, de werkstijl on de motivatie van de haio beinvloedt, variabelen die in deze studie niet zijn onderzocht. 
In de studie die wordt gepresenteerd in hoofdstuk 6 wordt de relatie onderzocht tussen proces en uitkomst in termen van groei in kennis van de eerste acht maanden huisartsopleiding. Een significante toename in gemiddelde kennistoetsscore werd aangetoond. Geen enkele van de onderzochte opleidingsvariabelen, aantal patiëntencontacten, opleider, praktijk, theoretisch curriculum, bleek een significant invloed op deze groei te hebben. Twee items betreffende de huisartsgeneeskundige $k$ waliteiten wan de opleider, lieten een negatief verband met groei in kennis van de haio zien. Hiervoor kon geen plausibele verklaring worden gevonden. Er werd een sterke relatie gevonden tussen het kennisniveau van de haio aan het begin van de opleiding en het niveau na acht maanden. Dit zou kunnen betekenen dat kenmerken van de haio, zoals leerstijl en motivatie, de groei in kennis gedurende de opleiding meer bepalen dan kenmerken van de opleiding. De inhoud van het theoretisch curriculum en het morbiditeitsaanbod zouden echter van aanvullend belang kunnen zijn. Deze variabelen waren niet in deze studie opgenomen.

In hoofdstuk 7 wordt een onderzoek beschreven dat tot doel had na te gaan, of kennistoetsen gebruikt kunnen worden in het kader van selectie voor of tijdens de opleiding. Tot nu toe worden kandidaten voor de opleiding geselecteerd op grond van een sollicitatiebrief en een gestructureerd interview. De betrouwbaarheid hiervan is matig en de voorspellende waarde hiervan laat, volgens de literatuur, veel te wensen over. $\mathrm{Na}$ acht maanden beslist het instituut of de haio de opleiding mag voortzetten. Van doorslaggevend gewicht hierbij is het oordeel van de opleider over het functioneren van de hato. Hoewel de opleider de aangewezen persoon lijkt om de haio te beoordelen, staat de 'dubbelrol" van beoordelaar en supervisor het vellen van een onbevooroordeeld oordeel in de weg.

Om na te gaan of kennistoetsing aan het begin van de opleiding of na acht maanden een waardevolle aanvulling zou zijn op de gebruikte selectie-methoden, werd de predictieve validiteit van de kennistoets onderzocht. De eindtoets, gemaakt kort voor het einde van de opleiding, fungeerde als criterium, of standaard, voor cle voorspellende waarde van de begintoets en van de achtmaand-toets en van een combinatie van beide. Een stapsgewijze multipele regressie-analyse, met de eindtoets als afhankeljjke variabele, liet zien, dat de voorspellende waarde van de begintoets en de achtmaand-toets alsmede van de combinatie van beide verwaarloosbaar klein was. Vervolgens werd nagegaan, in welke mate de eindtoets-resultaten konden worden voorspeld uit de eerder genoemde toetsen als de eindtoets-resultaten werden gedichotomiseerd, met ander woorden: als een zak-slaag grens zou worden gehanteerd. Er werden twee arbitraire afkappunten gekozen: het minimum-criterium ('beneden minimum' representeerde de scores van de 16\% laagst scorende haio's) en het excellent-criterium ('boven excellent' representeerde de scores van de 
$16 \%$ hoogst scorende haio's). De logistische regressie analyse liet zien, dat de voorspellende waarde van de begin en achtmaand-toets voor beide afkappunten laag was. De enige vitzondering was de negatief voorspellende waarde van de achtmaand-toets, gegeven het minimum-criterium: een score twee standaard-deviaties onder het gemiddelde op de achtmaand-test kwam in $100 \%$ van de gevallen overeen met een score beneden het minimum op de eind-toets. Dit had betrekking op $2.5 \%$ van de haio's. Terzelfdertijd werden $14 \%$ van degenen die op de eindtoets beneden het minimum scoorden, mier met de achimaand-toets 'opgespoord'. Beperking van de kans om na acht maanden haio's door te laten die op de eindtoets beneden het minimum scoren, zou gepaard gaan met een aanzienlijke vergroting van de kans om haio's na acht maanden onterecht af te wijzen (gezien hun score boven het minimum op de eindtoets). Dit geldt in versterkte mate als het excellent-criterium wordt gehanteerd.

In hoofdstuk 8 worden de belangrijkste conclusies gepresenteerd. De kennistoets is een geschikt meetinstrument om de groei in kennis van groepen haio"s te volgen en om, periodiek, sterke en zwakke kanten van de haio in kaart te brengen. Het gebruik van de toets als meetinstrument in de onderhavige studie naar de groei in kennis is gerechtvaardigd. Selectie van haio's vroeg in de opleiding op basis van kennistoetsresultaten is niet goed mogelijk wegens de lage predictieve validiteit voor het kennisniveau aan het eind van de opleiding. De gemiddelde groei in kennis gedurende de opleiding is echter substantieel, hetgeen resulteert in een bevredigend kennisniveau aan het eind van de opleiding. Er is geen bewijs gevonden voor een invloed van de afzonderlijke opleidingscomponenten op de groei in kennis van de haio.

Het feit dat er geen verband kon worden aangetoond tussen specifieke onderwijsinput en uitkomst in termen van groei in kennis, roept de vraag op of de kennistoets wel geschikt is om die kennis te toetsen die wordt verworven tijdens patiënt-contacten en besprekingen met de opleider.

Gesuggereerd wordt dat er mogelijk twee verschillende soorten huisartsgeneeskundige kennis bestaan: 'evidence-based' kennis, ofwel de keninis die in de vakliteratuur is vastgelegd, en 'experience-based' ofwel ervaringskennis, die wordt verworven in de individuele praktijkvoering en die toeneemt met klinische ervaring. De toetsinhoud zou dan vooral 'evidence-based' kennis vertegenwoordigen, terwijl de kennis die tijdens patiënten-contacten en contacten met de huisarts-opleider wordt overgedragen, grotendeels 'experience-based' is. Dit onderscheid leidt ertoe dat de bevindingen van de onderhavige studies gemakkelijker zijn te interpreteren. De afname van 'evidence-based' kennis met toenemende ervaring als huisarts is beter te begrijpen; de huisarts steunt in toenemende mate op zijn/haar 'experience-based' kennis. Zo is het ook beter te begrij- 
pen dat de opleider geen evidente invloed heeft op de groei in ("evidencebased') kennis van de haio.

De conclusie zou kunnen zijn dat de toets een operationalisatie is van het construct 'evidence-based' huisartsgeneeskundige kennis. Met betrekking tot het onderscheid tussen 'evidence-based' kennis en 'experiencebased' kennis zouden er twee soorten van 'expertise' moeten worden omschreven. De eerste refereert aan het ervaringsniveau als beroepsbeoefenaar, de tweede aan het expert zijn op een bepaald terrein. De eerste neemt min of meer automatisch toe met het antal jaar ervaring, de laatste veronderstelt een hoge mate van beheersing van geïntegreerde 'evidencebased' en 'experience-based' kennis.

De aanbevelingen voor opleiding en toetsing houden onder meer het volgende in. Als er vanuit wordt gegaan, dat 'evidence-based' kennis en 'experience-based' kennis van gelijk belang zijn, houdt een evenwichtige opleiding in, dat theorie en praktijk, opleidingsinstituut en opleider complementaire rollen vervullen. Bovendien zouden opleidingsinstituten haio's nadrukkelijk moeten stimuleren theorie en praktijk te integreren, onder andere door de vaardigheden van haio's in onderlinge toetsing en in kritisch lezen te ontwikkelen.

De kennistoets die in deze studie is gebruikt, wordt beschouwd als een waardevol instrument voor continu gebruik tijdens de huisartsopleiding. De voortgangstoetsvorm stelt de haio's in staat de eigen voortgang te volgen en het eigen onderwijs te plannen. Er bestaat nauwelijks enige noodzaak om haio's te selecteren op basis van toetsresultaten vroeg in de opleiding, gezien het bevredigende kennisniveau van de meeste haio's aan het eind van de opleiding. De evaluatie van zowel het onderwijs in de praktijk als het onderwijs tijdens de externe leerwerkperioden vraagt om toepassing van andere toetsmethoden dan de hier gebruikte. Er wordt een lans gebroken voor een certificerend examen dat een varièteit van methoden omvat, waarmee een scala aan cognitieve en niet-cognitieve vaardigheden kan worden getoetst. Kennistoetsing wordt tot een onmisbaar onderdeel daarvan gerekend. 



\section{Literature}

Anonymus. De positie van de huisarts in de toekomst. Discussienota. [The future position of the general practitioner. Discussion-paper] Utrecht: Landelijke Huisartsen Vereniging, 1987.

Baggen JL, Wan Leeuwen YD. Kans en differentiele diagnostiek. [Probability and differential diagnosis]. The Practitioner. 1984; 1379488.

Bensing JM. Doctor-patient-communication and the quality of care: an observation study into affective and instrumental behavior in general practice. Utrecht: NVEL, 1991.

Blalock HM. Applied multivariate analysis and experimental designs. Beverly Hills: SAGE Publications, 1984.

Bligh JG. Independent learning among general practice trainees: an initial survey. Med Educ 1992; 26: 497-502.

Boerma WGW, De Jong FAJM. Mulder PH. Health care and general practice across Europe. Utrecht: NIVEL/NHG, 1993.

Bordage $\mathrm{G}$, Grant J, Marsden P. Quantitative assessment of diagnostic abilaty. Med Educ $1990 ; 24 ; 413-25$.

Bordage G, Page G. An alternative approach to PMP"s: the "key features' concept. In: Hart IR, Harden RM, editors. Further Developments in Assessing Clinical Competence. Montreal: Heal Publications, 1987.

Borgiel AEM, Williams JI, Bass MJ, et al. Quality of care in family practice: does residency training make a difference? Can Med Assoc \1989: 1; 1035-43.

Borlase $\mathrm{BC}$, Bratle EJ, Moore EE. Does the in-service training examination correlate with clinical performance in surgery?

Boshuizen HPA. De ontwikkeling van medische expertise. Een cognitief-psychologische benadering. [The development of medical expertise. A cognitive psychological approach] [Dissertation]. Maastricht: University of Limburg 1989.

Boshuizen HPA, Schmidt $\mathrm{HG}_{\mathrm{y}}$ Coughlin LD. On the application of medicall basticscience knowledge in clinical reasoning: implications for structural knowledge differences between experts and novices. In: Proceedings of the 10th Annual Conference of the Cognitive Science Society. Hillsdale, New Jersey: Lawrence Erlbaum Associates, 1988.

Brennan RL. Elements of Generalizability Theory. Iowa City, Iowa: American College Testing Publications, 1983.

Bulte J, Tielens V, Visser S, Van der Ende J, Groenier K. De opleiding tot huisarts in de praktijk. [Practical training for GP trainees.] In: Bulte $J$, Van der Ende J, Helsper A, et al. De beroepsopleiding tot huisarts. [Training for general practicel. Nijmegen; KUN, 1988.

Buntinx F. The Cochrane Collaboration, information overload and European General Practice. Eur J Gen Pract 1995; 6: 19-29.

Byme PS, Freeman J. The assessment of vocational training for general practice. Journal of the Royal College of General Practitioners. [Occasional Paper]. London: Royal College of General Practitioners, 1976. 
Carmines $\mathrm{EG}_{4}$ Zeller RA. Reliability and validity assessment. Beverly Hills/London: SAGE publications, 1985 .

Crocker L. Algina I. Introduction to Classical and Modern Test Theory. Orlando: Holt, Rinehart and Winston, 1986.

Crombach LJ. How we should measure change - or should we? Psychol Bull 1970; 1: $68-80$.

Cronbach LJ. What price simplicity? Comment on: The pracucal validation of tests of ability [Ebel R. Educ Meas, issues pract 1983: 2; 7-10]. Edue Meas, issues pract $1983: 2 ; 11-2$.

Cronbach LJ, Gleser GC, Nanda $\mathrm{H}_{*}$ Rajaratnam N. The Dependability of Behawioral Measurements. Theory of Generalizability for Scores and Profiles. New York: Wiley, 1972.

Day $\mathrm{SC}$, Norcini $\mathrm{JJ}_{\mathrm{s}}$ Webster GD, Viner $\mathrm{ED}$, Chirioco AM. The effect of changes in medical knowledge on examination performance at the time of recertification. Proceedings of the $27^{\text {th }}$ Annual Conference of Research in Medical Education. Chicago, Ill: Association of American Medical Colleges, 1988.

De Groot AD. Het denken van den schaker. [The thinking of the chess player.] "s Gravenhage: Mouton, 1946.

Derese A. Huisarts in beroepsopleiding [Dissertation]. [Trainee in general practice.] Ghent: University of Ghent, 1992.

De Vries $B$. Het leven en de leer. Een studie naar de verbinding van leren en werken in de stage [Dissertation]. [Life and leaming. A study of the relation between learning and working in practical training]. Nijmegen: Instituut woor Toegepaste Sociale Wetenschappen, 1988.

Dubois V, Everwijn S, Van Geldorp G, et al. The construction of a new curriculum of vocational training for general practice in the Netherlands. Utrecht: Royal Dutch Medlical Association, 1987.

Ebel R. The practical validation of tests of ability. Educ Meas, issues pract 1983:2; $7-10$.

Ewidence-Based Medicine Working group. Evidence based medicine: a new approach to teaching the practice of medicine. JAMA 1992; 268: 2420-5.

Farmer E, Taylor S. Assessment of teaching by family medicine programme vocational trainees. Aust Fam Physician 1990; 4: 549 557.

Feltowich PJ, Barrows HS. Issues of generality in medicall problem solving. In: Schmidt HG, De Volder ML, editors. Tutorials in probllem based leaming; a new direction in teaching the health professions. Assen: van Gorcum, 1984: 128-42.

Fijten G, Kruithof MI, Muris JWM. Registratieproject arts-assistenten beroepsop leiding to huisarts. [Registration project trainees in general practice]. Maastricht: University of Limburg, 1988.

Flanagan JC. The critical incident technique. Psychol Bull 1954: 1; 327-57.

Flemming DM. The European study of referrals from primary to secondary care.

[Dissertation]. Amsterdam: Thesis Publishers, 1993. 
Freeman $J$, Roberts $J$, Metcalf $D$, Hillier $V$. The influence of urainers on trainees in general practice. [Occasional paper 21]. London: Royal College of General Practitioners, 1982.

Glaser R. Education and thinking: the role of knowledge. Am Psychol 1984; 39 : $93-104$.

Grant J, Marsden P. The structure of memorized knowledge in students and clinicians: an explanation for diagnostic expertise. Med Educ 1987; $21: 92-8$.

Grol R, Everwijn S, Dubois V. De meerjarige beroepsopleiding tot huisarts. IV: Opzet curriculum. [The three year curriculum for postgraduate training for general practice. IV: curriculum design]. Medisch Contact 1987:9: 279-82.

Grol $R_{n}$ Mokkink $H$, Helsper-Lucas $A$, Tielens $V$, Bulte J. Effects of the vocational training of general practice consultation skills and medical performance. Med Educ $1989 ; 23: 512-21$.

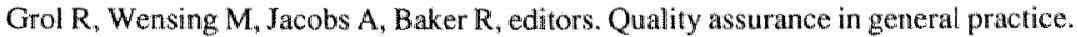
The state of the art in Europe. Utrecht: Nederlands Huisartsen Genootschap, 1993.

Hay J, Acheson RM, Reiss BB, Evans CE. Teachers in general practice: a comparative study. Med Educ 1980; 14:277-84.

Hobbs J, Mongan P. Miller MD. A system for assessing clerkship experience using at logbook and microcomputers. Family Medicine; 4: 287-90.

Hobus P. Expertise van huisartsen. [Dissertation], [Expertise of general practitioners.] Maastricht: Rijksuniwersiteit Limburg, 1994.

Irby DM. Clinical teacher effectiveness in medicine. J Med Educ 1978; 53; 808-15. Irby DM, Ransey PG, Gillmore GM, Schaad D. Characteristics of effective clinical teachers of ambulatory care medicine. Acad Med 1991; 1: 54-5.

Janssen JM, Tan LHC, Van der Vleuten CPM, Pielage JC, Grol R.PTM. Assessmenth of technical skills in general practice: comparing different formats for use in quality control. In: Harden RM. Hart IR, Mulholland H, editors. Approaches to the Assessment of Clinical Competence. Dundee: Centre for Medical Education, 1992.

Kane MT. The validity of licensure examinations. Am Psychol 1982: 8; $911-8$.

Keane DR, Blake JM, Norman GR, Mueller CB. Introducing progress testing in a traditional problem-based curriculum: psychometric properties. Suppl Acad Med, (in press).

Kelly DR, Murray TS. An assessment of vocational training. Med Edtuc 1992; 26: 402-5.

Klaassen T, Van der Vleuten CPM, Rotteveel RJ. De betrouwbarhied vatn het mondelinge examen nader bekeken. [Renewed appraisal of the reliability of orals. Bulletin Medisch Onderwijs 1994: 13: 155-61.

Kramer AWM, Pollemans MC. Nationwide progress tests assessing knowledge in vocational training for general practice. In: Bender W, Hicmstra RJ, Scherpbier AJJA, Zwierstra RP, editors. Teaching and Assessing Clinical Competence. Groningen: BoekWerk Pub], 1990. 
Kramer AWM, Pollemans MC, Van Leeuwen YD. Het toetsen wan kennis in de beroepsopleiding tor husarts [Assessment of knowledge in vocational training]. Medisch Contact 1990; 7: 2202.

Lamberts $H_{1}$ Ouwehand $\mathrm{G}$. Een arts-assistent in een hüsartspraktijk. Het werk en de plasts van de arts-assistent in opleiding gek wantificeerd. [Trainee in general practice. Quantification of the work and position of the trainee in general practicel. Husarts Wet 1982; 25:4-10.

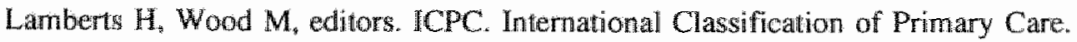
Oxford: Oxford University Press, 1987.

Landlsbergen EP. 'Nailing red jelly to the wall'. Selectie voor de medische vervolgopleiding. [Selection for medical postgraduate training]. In: Van der Vleuten CPM, Scherpbier AJJA, Pollemans MC, editors. Gezond onderwijs. Houten: Bohn, Stafleu, Van Loghum: 1992.

Lawrence M, Pritchard P, editors. General Practitioner Education. UK and Nordic Perspectives. London: Springer Verlag, 1992.

Leigh TM, Johnson TP, Pisacano NI. Predictive validity of the American board of family practice in-training examination. Acad Med 1990; 65: 454-7.

Leigh TM, Young PR, Haley N. Performances of family practice diplomats on successive mandatory recertification examinations. Acad Med 1993; 68: 912-9.

Lewis BS, Pace WD. Qualitative and quantitative methods for the assessment of clinical perceptors. Fam Med 1990; 5: 356-60.

Lockie $\mathrm{C}$, editor. Examination for Membership of the Royal College of General Practitioners (MRCPG). Development, current state and future trends [Occasional Paper 46]. London: Royal College of Generall Practitioners, 1990.

Lohr KN. Guidelines for clinical practice: applications for primary care. Int I Qual Health Care 1994; 6: 17-25.

Luke C, Kadzombe E, Gorman D, Armstrong A. An evaluation of a logbook for trainees in accident \& emergency medicine in the United Kingdom: senior consultant opinion. Archives of Emergency Medicine 1993; 10:43-7.

Marshall J. Assessment during postgraduate training. Acad Med 1993; 68:23-6.

McDonald PJ, Bass MJ. Characteristics of highly rated family practice perceptors. J Med Educ 1983; $58: 882-93$.

Meskauskas JA, Webster GD. The American Board of Internal Medicine Recertification Examination: process and results. Ann Int Med 1975; 82: 577-81.

Murphy A. The hospital component of general practice vocational training: persistent preventable problems. Education for General Practice 1995; 6: 19-29.

Nagel E The Structure of Science. Problems in the logic of scientific explanation. Londion: Routledge \& Kegan Paul, 1982.

Nelson MS, Clayton BL, Moreno R. How medical school faculty regard educational research and make pedagogical decisions. Acad Med 1990; 65: 122-6.

Neufeld VR, Norman GR, editors. Assessing Clinical Competence. New York: Springer Publishing Company, 1985. 
Newble D, Jolly B, Wakeford R, editors. The Certification and Recertification of Doctors: Issues in the Assessment of Competence. Cambridge: Cambridge Universily Press, 1994.

Norcini J, Lipner RS, Benson JA, Webster GD. An analysis of the knowledge base of practicing internists as measured by the 1980 recertification examination. Ann Intern Med 1985; 102: 385-9.

Norman $G$. Can an examination predict competence? The role of recertification in maintenance of competence. Annals RCPSC 1991; 2: 121-4.

Norman $G$, Allery L, Berkson L, et al. Research in the psychology of clinical reasoning: implications for assessment. In: Jolly B, editor. New Directions in the Assessment of Clinical Competence. Proceedings Cambridge Conference IV. Cambridge: Cambridge University Press, 1989.

Norman GR, Rosenthal D, Brooks LR, Allen SW, Muzzin LJ. The development of expertise in dermatology. Ach Dermatol 1989; 125: 1063-8.

Patel VL Groen GJ. Knowledge based solution strategies in medical reasoning. Cognit Sci 1986; 10: 91-116.

Pereira Gray DI. Training for general practice. London: Butler \& Tanner Ltd, 1982.

Pereima Gray DI. Assessment at last [Editorial]. Br J Gen Praet 1993; 43: 402-3.

Pieters HM, Touw-Otten FW, De Merker RA. Simulated patients in asessing consultation skills of trainees in general practice vocational training: at validity study. Med Educ 1994:28: 226-33.

Pisacano NJ, Veloski JJ, Brucker PC, Gonnella JS. Classifying the content of boand certification examinations. Acad Med 1989: ii; 149-54.

Pollemans MC. Kennistoetsing bij huisartsen [Dissertation]. [Testing of knowledge of general practitioners.] Maastricht: DatawysedUniversitaire Pers Maastricht. 1994.

Pollemans MC, Tan LHC. Toetsing wan kwaliteit. Landelijke evaluatie wan de interim-beroepsopleiding tot huisarts [rapport SV-IOH-15]. [Testing of quality. Nationwide evaluation of the two-year postgraduate training for general practice $\|$. Utrech: Samenwerkingsverband-10H, 1990.

Pollemans MC, Van Geldorp G, Tan LHC. Naar kwalteitsbewaking van de beroepsopleiding tot huisarts. [Towards quality ascessment of vocational training of general practioners]. Medisch Contact 1988; 43(46): 1429-30.

Pollemans MC, Van Leeuwen YD, Düman H, Eekhof JAH, Mol SSL. Achiergronden blauwdruk huisantsgeneeskundige kennistoets. [Background of the blueprint of the Dutch knowledge test for general practicef. Utrecht: Samenwerkingsverbatid IOH, 1993.

Rethans $J_{*}$ Stumans F, Drop $R$, Van der Vleuten C. Assessment of the performance of general practitioners by the use of standardized (simulated) patients. Br J Gen Pratct 1991; 41:97-9.

Ridsdale L. Evidence-based general practice. A critical reader. London: Saunders Company Litd, 1995.

Ronalds C, Douglas A, Pereira Gray, Selley P. Fourth National Trainee Conference. Report Reconmendations and Questionnaire. [Occasional paper 181. London: Royal College of General Practitioners, 1981.

Rutten GEHM. Thomas S, editors. NHG-Standatarden voor de huisaris. [Practice Guidelines for the General Practitioner.] Utrecht: Bunge, 1993. 
Sacken DL. Haynes RB, Tugwell P. Clinical epidemiology. A basic science for medicine. Boston/Toronto: Litte, Brown and Company, 1985.

Schmidt HG, Boshuizen HPA. On acquiring expertise in medicine. Educational Psychology Revicw 1993; 5: 202-21.

Schmidi $H G$, Noman GR, Boshuizen HPA. A cognitive perspective on medical expertise: theory and implications. Acad Med 1990; 65:61:-21.

Springer MP, editor. Basistakenpakket voor de huisarts [Basic job description for the general practitioner]. Utrecht: Landelike Huisartsen Vereniging, 1983.

Stolk J, Pollemans MC. Institutsonderwijs in de berospsopleiding tot huisarts. [Theoretical education in postgraduate training for general practice.] Bulletin Medisch Onderwijs 1991; 3: 94-9.

Stolk J Tan LHC. Opleidingscontacten in de huisartspraktijk [Educational encounters in general practice.] Bulletin Medisch Onderwijs 1992; 11:62-6.

Swanson D, Case $\mathrm{S}$. Trends in written assessment: a strangely biased perspective. In: Harden $\mathrm{R}$, Hart $\mathrm{R}$, Mulholland $\mathrm{H}$, editors. Approaches to the Assessment of Clinical Comperence. Dundee: Centre for Medical Education, 1992.

Tan LHC. Tekorten in de opleiding van huisartsen [Dissertation]. [Deficiencies in the training of general practitioners.] Amsterdam: University of Amsterdam, 1989.

Tan LHC, Foolen CHGM, Van der Vleuten CPM. Ontwikkeling van de landelijke consultwoeringstoets voor de beroepsopleiding tot huisarts. [Development of the nationwide test of consultation skills for postgraduate training in general practice]. Bulletin Medisch Onderwijs 1992; 11:22-33.

Thorndike RL. Reliability. In: Keeves JP, editor. Educational Research, Methodology, and Measurement. An International Handbook. Oxford: Pergamon Press, 1988: $330-43$.

Van Berkel HJM. De diagnose van toetsvragen [Dissertation]. [The diagnosis of test items. Amsterdam: Centrum voor Onderzoek van het Wetenschappelijk Onderwijs (COWO), Universiteit van Amsterdam, 1984.

Van der Vleuten C, Newbie D, editors. Methods of assessment in certification. In: Newble D, Jolly B, Wakeford R, editors. The Certification and Recertification of Doctors: Issues in the Assessment of Competence. Cambridge: Cambridge University Press, 1994.

Van der Vleuten CPM, Van Leeuwen YD, Mol SSL, Düsman H, Tan LHC, Grol R. Betrouwbarheid van onderwijsregistraties in praktijkstages. IReliability of educaVional registrations in practical training periods]. In: Houtkoop $E$, Pols $J$, Pollemans MC, Scherpbier AJJA, Verwijnen GM, editors. Gezond Onderwijs III. 's Gravenhage: Haagse Hogeschool, 1994.

Van der Vleuten $\mathrm{C}$, Verwijnen M. A system for student assessment. In: Van der Vleuten C. Wijnen W, editors. Problem-based leaming: Perspectives from the Maastricht experience. Amsterdam: Thesis, 1990.

Van Geldorp $\mathrm{G}$, redactie. Opleiden en leren in de huisartspraktijk. ITraining and learning in general practice.] Utrech: Bunge, 1985.

Van Leeuwen YD. Evaluatie van de beroepsopleiding tot huisarts: Toetsstenen en struikelblokken. [Evaluation of postgraduate training in gerweral practice.] Medisch Contact 1983; 33:1023-6.

Van Leeuwen et al. The Dutch knowledge test for general practice: issues of validity. The European Joumal of General Practice 1995; $1: 113$-7. 
Van Leeuwen et al. Change in knowledge of gereral practioners during their professional career. Famliy Practice 1995; 12:313-7.

Van Leeuwen YD, Van Hessen PAW. Clinical competence and objective questions: Tactics to realize a true/false format assessing competence. In: Bender W, Hiemstra RJ, Scherpbier AJJA, Zwierstra RP, editors, Teaching and Assessing Clinioal Competence. Groningen: Boek Werk publications, 1990.

Van Thiel $J$, Kraan $\mathbf{H}$. Van der Vleuten $C$. Reliability and feasibility of measuring medical interviewing skills: the revised Maastricht History-taking and Advice Checklist. Med Educ 1991; 25: 224-9.

Van Thiel J, Van der Vleuten C, Kraan H. Assessment of medical interviewing skills: generalizability of scores using successive MAAS-versions. In: Harden RM, Hart IR, Mulholland $H$, editors. Approaches to the Assessment of Clinical Competence. Dundee: Centre for Medical Education, 1992.

Verwijmen GM, Imbos Tj, Snellen H, et al. The evaluation system of the medical school of Mastricht. Assessment and Exaluation in Higher Education 1982; 3: $225-44$.

Wright PM, Lichtenfels PA, Pursell ED. The structured interview: additional studies and a meta-analysis. Journal of Occupational Psychology 1989; 62: 191-9.

Ybema $\mathrm{D}$, Jasper $\mathrm{R}$, Groenier $\mathrm{K}$. Meningen en wensen van pas gevesigde huisartsen ten aanzien van de vorm en inhoud van de beroepsopleiding tot huisarts. JOpinions and wishes of recently established GPS regarding the form and contents of postgraduate training for general practice.] Groningen: University of Groningen, 1983. 


\section{Curriculum vitae}

Yvonne Deliana van Leeuwen was born on the ninth of November 1951 in Leiden and grew up in the south east of Brabant, the Netherlands. In 1970 she finished her Gymnasium B at the Eindhovens Protestant Lyceum and studied medicine at the University of Groningen, where she graduated in 1978. After a residentship of six. months in internal medicine in Italy, she undertook postgraduate training for general practice at the University of Limburg, with Jo Baggen, general practitioner in Brunssum as her trainer. Subsequently, she worked as a locum while attending lectures in philosophy at the Hogeschool yoor Theologie en Pastoraat in Heerlen. Since 1981 she has been attached to the University of Limburg. Initially involved in assessment and evaluation in undergraduate medical education, her more recent interests have been in postgraduate training for general practice, including the supervision of groups of trainees, lecturing and assessment and evaluation. She contributed to a national system of assessment in postgraduate training, in particular, the development of the knowledge test that forms the content of this dissertation. In 1986 she completed a one year course in 'research for general practice'. From January 1994 she has participated in the national Core Training for General Practice (SGO), exploring several aspects of general practice: impaired hearing, primary care ophthalmology, chronic pain and palliative medicine. From 1981 she has been a part-time general practitioner, for the last nine years in the Health Centre Neerbeek, near Maastricht. 